\title{
THE MAKING
}

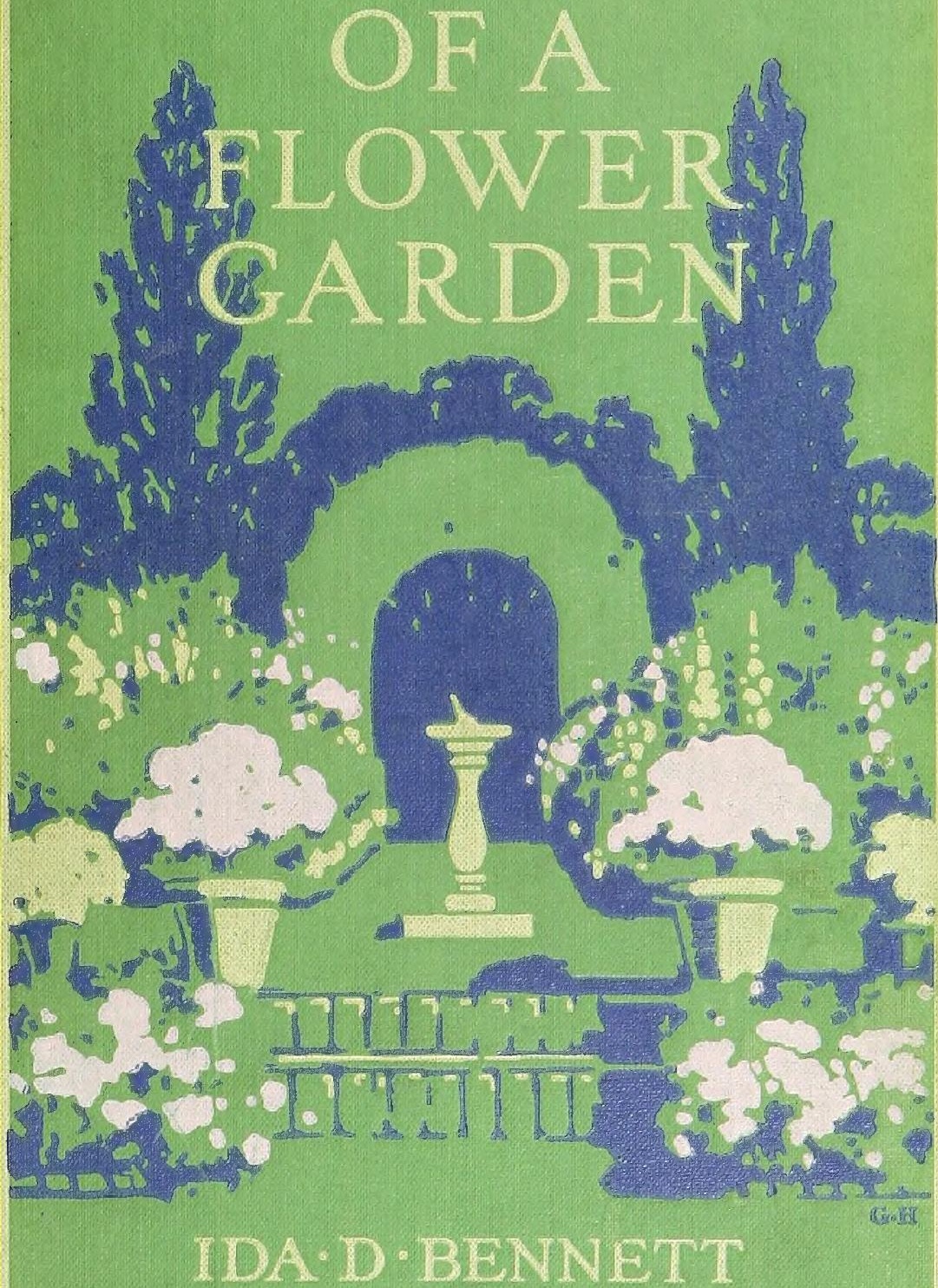




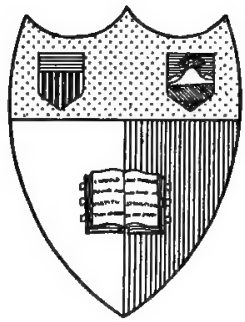

\section{Avew 焽的k \\ State Callege of Anrinulture}

At Garnell Alniugesity

Jthara, 2. 翨.

\section{Fithrary}


SB 405 Cornell University Library

The making of a flower garden,

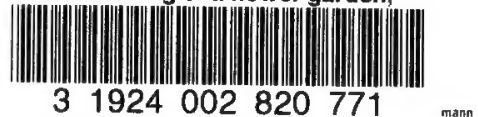


$-$

$$
\text { - }
$$




\section{THE MAKING OF A FLOWER GARDEN}




\section{Cornell University Library}

The original of this book is in the Cornell University Library.

There are no known copyright restrictions in the United States on the use of the text.

http://www.archive.org/details/cu31924002820771 



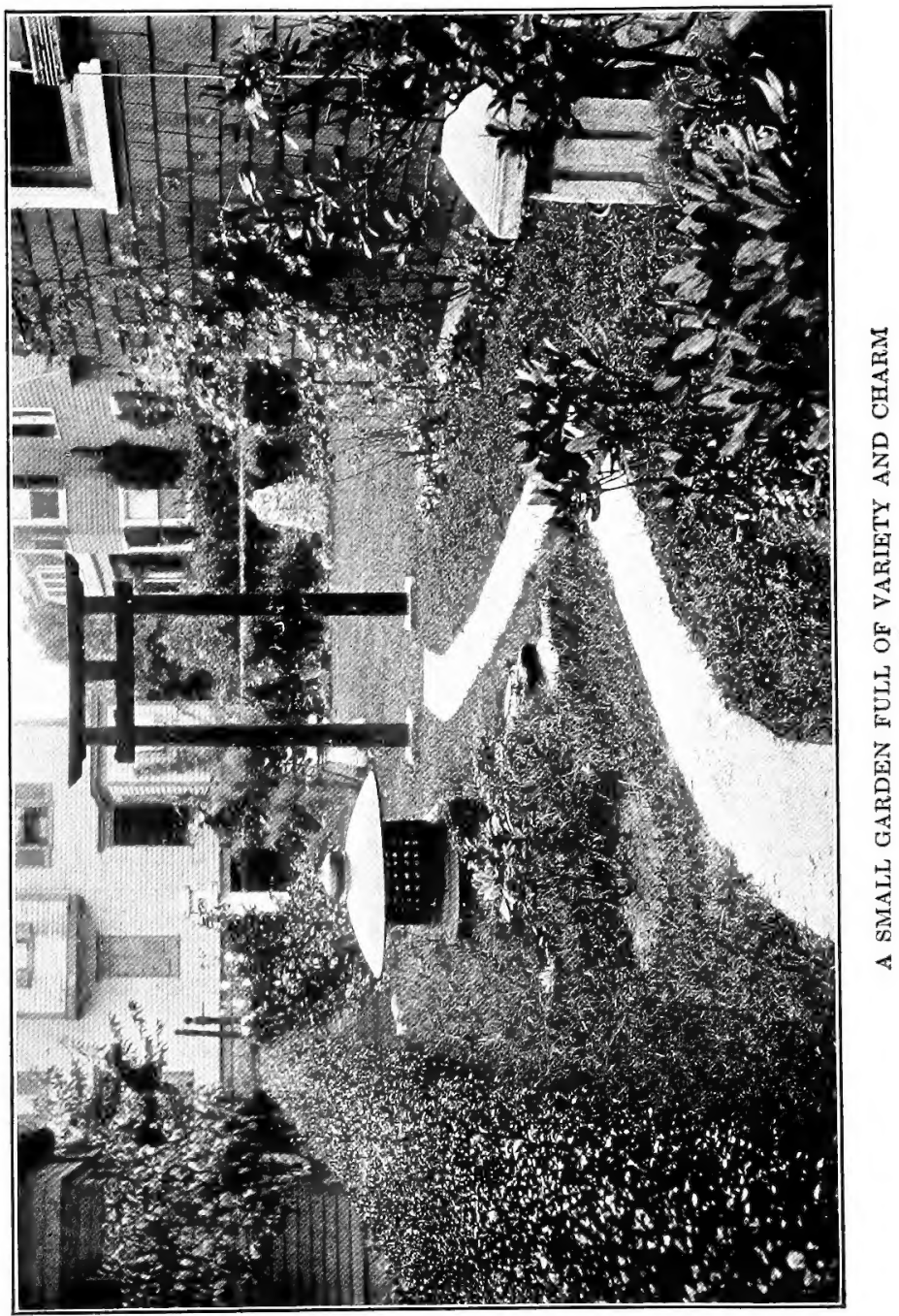






\section{THE MAKING OF A FLOWER GARDEN}

BY

\section{IDA D. BENNETT}

Author of "The Flower Garden," "The Vegetable Garden," etc.

WITH FOUR DIAGRAMS AND SITTEEN ILLUSTRATIONS FROM PHOTOGRAPHS

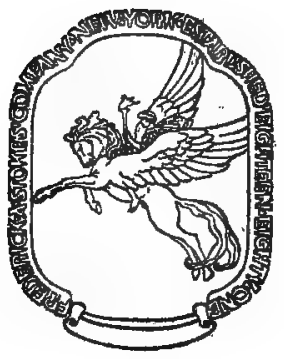

NEW YORE

FREDERICK A. STOKES COMPANY

PUBLISHERS 
XX. Plant Enemies and Insecticidims . 208

XXI. The Value of a Definite Color Scheme in the Garden; a White, a Red, a Yellow and a Blue Gardin, With Table of Plants . . . 215

XXII. Bird Hodses, Natatoriums and Feeding Stations . . . . . . . . . 226

Tabli of Germination of Semps . . 242

INDEX . . . . . • • • . . 245 


\section{LIST OF ILLUSTRATIONS}

A small garden full of variety and charm Frontispiece

Does thi look like a promising garden gpot? Does this look like a promising garden spot? - 16 The result of a flower lover's work in one year . 16 As a low hedge plant the hydrangea paniculata is unexcelled . . . . . . . . . 17

A lovely mass of heliotrope, ageratum and tritomas . . . . . . . . . . . 48

A successful treatment of a triangular space between drives . . . . . . . . . . . . . $\quad .49$

Red and white tulips used as a border for shrubbery . . . . . . . . . . . . 74

A wide border of hyacinths and pansies . . . 75

A small back yard devoted to roses . . . . 102

A rose arch is a most effective support for climbing roses . . . . . . . . . . . 103

A thrifty window box two months after planting. 124 Vines effectively used as porch decoration . . 125 Funkia overhanging a pool planted with water poppies . . . . . . . . . . . 142 Iris used as a border for a pond . . . . . 143 A hardy border of larkspur and hollyhocks . . 152 Foxglove planted against a background of shrubbery 



\title{
THE MAKING OF A FLOWER GARDEN
}

\author{
CHAPTER I
}

THE LOCATION

WHEN one takes up the subject of the location of a garden one has to consider at the start just what advantages are afforded by the piece of ground comprising one's special domain. If it consists merely of a city lot with its few feet of turf in front and a few square yards of wall-enclosed back yard, the problem will be the simple one of making that little patch of ground as attractive and prolific of bloom and beauty as possible; and there are harder problems by far than this, though an undeveloped city back yard may look hopeless enough to the uninitiated. The small town lot affords greater advantages, as there is usually considerable space at the side or rear of the dwelling to allow of mass planting about boundaries and often of the laying out of a more or less formal 
garden at one side. This is, of all, the happiest arrangement-that the garden shall be so situated as to be visible from the living-room windows, especially from those occupied by the busy mistress of the home. Usually the home is built and the garden added as an afterthought; this often results in an unfortunate placing, both from a practical and an æsthetic point of view. That the garden should be sufficiently retired from the street to insure privacy, and at the same time close enough to the house to become an intimate part of the life of the home, goes without saying. And this is only secured when the garden comes to us, through vistas opened by the friendly windows, so that one may pause from time to time in the day's employment to enjoy its beauty or run out for a moment or two's work among the flowers. A garden that takes one far from the house will not receive the constant intimate attention that is the heritage of the one where odd moments are utilized; one plans for spare hours in the one, for spare moments in the other.

1 The plans illustrated, while by no means the last word in garden arrangement, should be helpful in planning the small place garden or the arrangement of a city lot.

In Plan A the house is centrally located on the lot and both a flower and a vegetable garden are arranged for, with considerable planting of shrubbery about the 
base of the house and an inviting circle of turf in front of the rear door.

The radiating beds of the flower garden are exceptionally favorable where one wishes to grow a great variety of flowers and shrubs in a restricted area, as low-growing perennials and annuals may occupy the fore part of the beds and larger growths be gradually introduced as the beds recede until, in the rear, they give place to tall shrubs or small ornamental trees. This form of planting greatly increases the apparent extent of the grounds and also serves as a screen for. unsightly objects in the rear. The long, straight paths make the care of the beds a simple affair and the number of beds and paths may be regulated according to the ground at command.

A beautiful arrangement of the planting would be to run a triple row of tulips, hyacinths or narcissi along the edges of all the beds and sow English daisy seed, pansies, ageratums or other low-growing plants among them to cover the ground when they are through blooming. On the less sunny borders the lobelias would be beautiful, as would the dwarf morning glories which remain open all day. The tufted pansies are permanent and beautiful border plants, especially the yellow ones, and one can compose very artistic color schemes by using flowers that harmonize with the edging plants in the different beds.

Plan B is a much more formal laying out of a city 


\section{PLAN A}

Babe Planting About Hougn

A. Spiraes Van Houttei

B. Bocconia

C. Hydrangea paniculata

\section{BEDI}

D. Pronies

F. Shasta Daisies

F. Gladioli

$X$. Auratum and Candidum Lilies

BED 2

G. Asters

H. Nicotiang affinis

I. Salvias

J. Forsythias

K. Tamarix

BED 3
Hight Color

$4^{\prime}-5^{\prime}$ White

$5^{\prime}-8^{\prime}$ Flesh color

$5^{\prime} \quad$ White
June

July

Aug.-Sept.

June-July

$$
\begin{aligned}
18^{\prime \prime}-2^{\prime} & \text { White,pink, red } \\
18^{\prime \prime}-2^{\prime} & \text { White } \\
2^{\prime}-3^{\prime} & \text { Various colors } \\
3^{\prime}-5^{\prime} & \text { White }
\end{aligned}
$$

$18^{\prime \prime}-2^{\prime}$ Various colors

$2^{\prime}-3^{\prime}$ White,rose, $\theta$ to.

$2^{\prime}-6^{\prime}$ Scarlet

$8^{\prime} \quad$ Yellow

$8^{\prime}-12^{\prime}$ Pink

L. German Iris

May-Juno

M. Foxgloves

June-July

N. Deutzia(Pride of Rochester) June

$$
\begin{array}{ccc}
2^{\prime} & -3^{\prime} & \text { All oolors } \\
2^{\prime} & -4^{\prime} & \begin{array}{c}
\text { White, rose, } \\
\text { purple }
\end{array} \\
6^{\prime} & -8^{\prime} & \text { White }
\end{array}
$$

\section{BED 4}
o. Anthericums
May
P. Aquilegis:
June
Q. Delphiniums (Gold Medel June-July Hybrids)

R. Buddleis variabilis.

July.

$18^{\prime \prime}-2^{\prime}$ White

$2^{\prime} \quad$ All colore

$2^{\prime}-6^{\prime}$ Blue, white

6'. Violet 


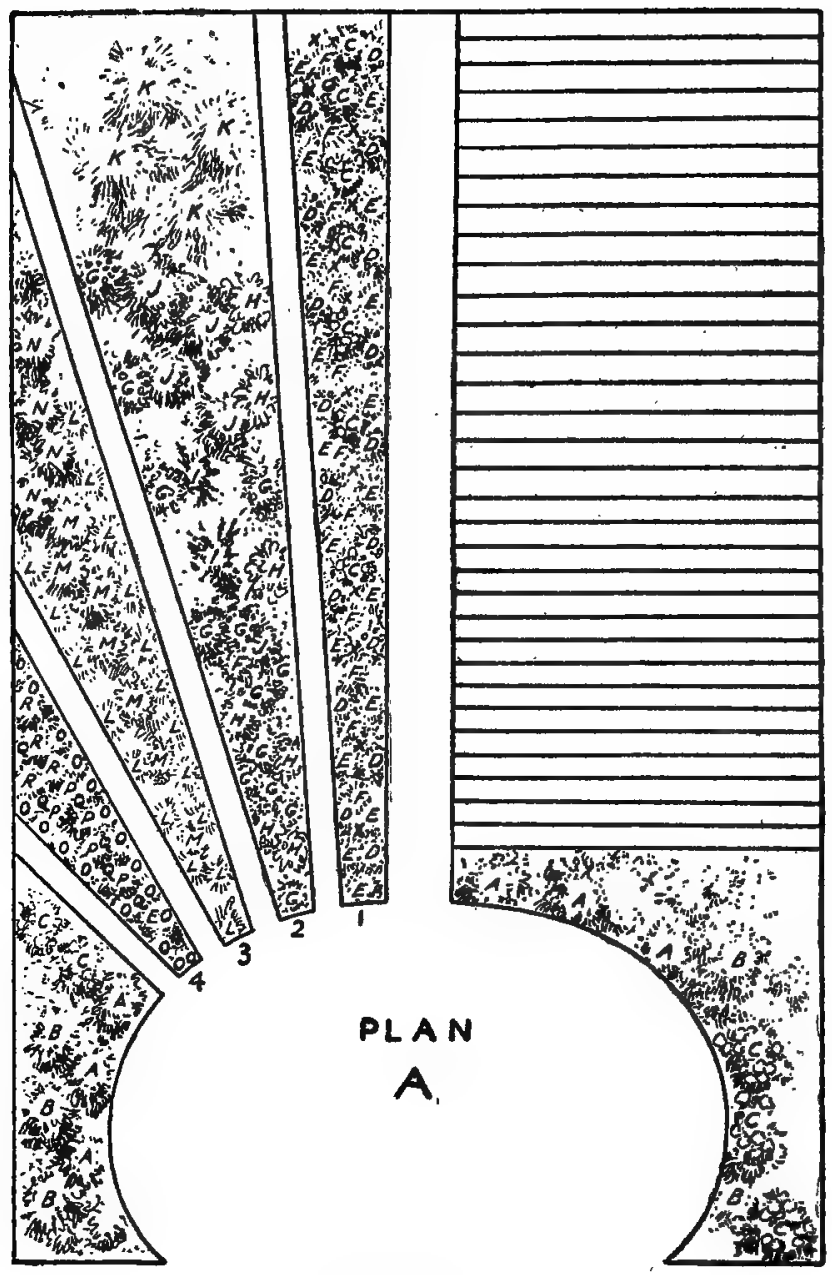

Puan A 


\section{PLAN B}

Broox

B. Pool inlgarden; plant Water June-frost Lilies

X. Trellis in rear-Ampelopais June-frost tricolor

XX. Side trellises-Clematis Aug.-Sept. paniculats

Sunny side of garden;
A. Ageratum
All oummer
B. Delphiniums
July-Aug.
C. Auratum and Candidum June-July Lilies

D. Tritomas

Aug,--Host

E. Feverfew

July

F. Asters

July-Sept.

G. Lychnis and Garden Spiraea

H. Physostogia

July

I. Clethra alnifolia

Mid-summer

J. Chionanthus

K. Altheas
HEIOET yellow white

Trailing Blue berries

15' White $6^{\prime \prime} \quad$ Blue

$3^{\prime}-6^{\prime}$ Blue, whito

$3^{\prime}-4^{\prime}$ White, red epots

$2^{\prime}-3^{\prime}$ Flame color

$2^{\prime} \quad$ White

15"-18" Blue, white, red

2' -3 ' Scarlet

4' -6 ' White, pink

$3^{\prime}-5^{\prime}$ White

Tree White

Tree White, red, etc.

Shady side of garden;
A. Funkias
Aug.-Sept.
$2^{\prime}$
White
B. Azaleas
Jute
$2^{\prime}-4^{\prime}$ Red, white
C. Rhododendrons
June
D. Hydrasgea arborescens
June
$2^{\prime}-8$ Red, white
E. Salvias
Aug-Sept.
4' $-6^{\prime}$ White
F. Nicotiana Bylvestris
All summer
$2^{\prime}-5^{\prime}$ Scarlet
$4^{\prime}-6^{\prime}$ White
G. Dogwood
May
Tree White
H. Cercis Canadenais (Judas April
5' Rose color Tree)

Pots on ateps of porch; Chinese Hibiscus in variety, or Bambusa Motake may be used. 
WEST

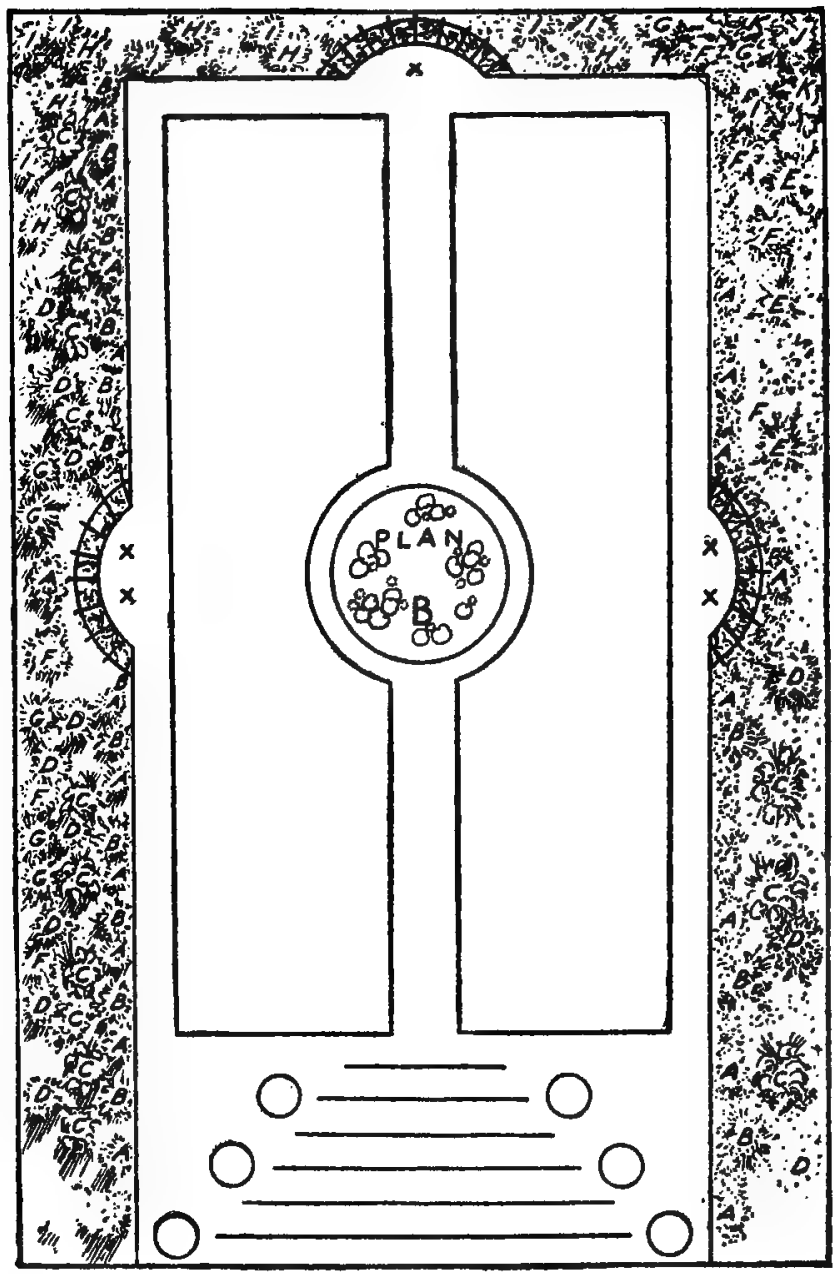

Pluan B 
back yard, where utility is not so much considered as artistic effect. By using brick or stone division walls, cement walks and the like, considerable outlay may be indulged in, but the result will be permanent and satisfying. A very artistic effect may be achieved however, by the use of wooden trellises painted white, gravel or cinder paths and garden seats of wood. If a pool in the center is adopted it should be of concrete. Where this is not desired a rustic summer house may be substituted or a fountain or even a round garden seat, or a beautiful tree.

Plan $\mathrm{C}$ with its accompanying table of planting is happily arranged at the side of the house, so fully in view from the windows of the living room and from the porch as to form an integral part of the whole. If a pergola outlines the half circle which characterizes the beginning of the garden it will form one more note in the symphony of the whole, or, if the porch is extended to cover the entire area between house and garden with steps leading to each separate path, rather than one broad series of steps, the result will be quaint and harmonious.

Much attention has been paid in this design to the working out of a color scheme for the several beds, and careful attention to the harmony of adjacent beds. The same idea may be worked out in plans $\mathbf{A}$ and $\mathbf{D}$. In this plan, as in $A$, the beds should all be edged with 
early spring flowering bulbs and later with blooming annuals or flowers of low growth.

Plan D is an especially interesting plan for a formal garden, designed without special reference to the house, though it may be arranged quite as intimately as any of the others. Its special claim to preference lies in the fact that it may be extenced from the small quarter of a circle, designed to fit into an odd bit of ground, to a half and even a whole circle, thus making an imposing formal garden. Like all the plans, consideration is given to the planting of low forms of flowers in the immediate foreground, pansies being especially suggested for the encircling outer beds, though verbenas or nasturtiums may be used where a more brilliant color scheme is desired. Where the quarter or half circle is used, then tall perennials, shrubs and the like may be employed in the rear and in the straight beds which border the design; but when the complete circle is adopted, then it will be best to keep the height of the entire planting rather uniform so as to have more the effect of carpet bedding. It is charmingly adapted to a rose garden and, if desired, the central beds may be devoted to rose trees rather than to the lower growths.

For the practical care of a garden there is nothing so good as clean, well-cared for gravel or cinder paths, especially if some sort of curbing is used to confine the beds. Bricks laid in the old-fashioned saw-tooth pat- 
PLAN C

\section{BED 1.-Blog and White}
A. Ageratum
B. Heliotrope
C. Aquilegias
D. Delphiniums (Gold Medal Hybrids)

E. Buddleias

F. Hyacinths, King of the Blues

May

All summer
All summer
June
July-fall

BED 2,-YELLOW AND WEITE
A. Sweet Alyssum
B. Anthericums
C. Anemones
D. Bachelor Buttons, double
E. Coreopsis, dwarf
F. Lemon Lilies
G. Kerría
H. Foraythia

Border with triple rows of yellow, tulips

All summer

May

Sept.-Oct.

July

July-Sept.

June-July

May

April

BED 3.-Scarleit and White
A. Candytuft
B. Verbenas
C. Shasta Daisies
D. Scrrlet Lyehnis
E. Nicotiana affinis
F. Salvias
G. Spiraea Van Houttei
H. Altheas
All summer
All summer
July
July
All summer
July on
June
Sept.

Border with scarlet and white tulips

\section{BED 4.-Rose and White Shadeg}
A. English Dajisy
All summer
B. Petunias, large flowered
C. Vincas
D. Scabiosa
E. Weigelia
All summer
All summer
June-July
May-June

Border with red and white tulips

BED 5.-Rose and Weite Shades
A. Paonies
B. Candidum Lilies
C. Auratum Lilies
E. Gladioli
June
June
July
Aug.-Sept.
18" Red, whits
$2^{\prime}-3^{\prime}$ White
$3^{\prime}-5^{\prime} \quad$ White, red

\section{Cozon}

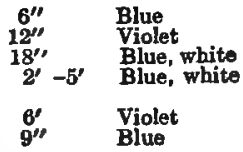

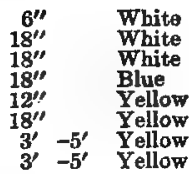

Trailing Red, white

15" Red, white

$18^{\prime \prime}-24^{\prime \prime}$ Red, white

Rose, white

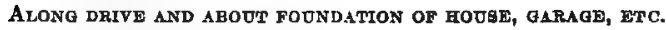
1. Hypericum Moserianum
2. Spiraea Van Houttei
3. Deutzia (Pride of Rochester)
4. Altheas
July
May
5. Tamarix in variety
Sept.-Oct
1' Yellow

This is a very interesting planting, as the carrying out of the color scherne in each bed gives opportunity for study and research, resulting in tnuch enjoyable knowledge. 


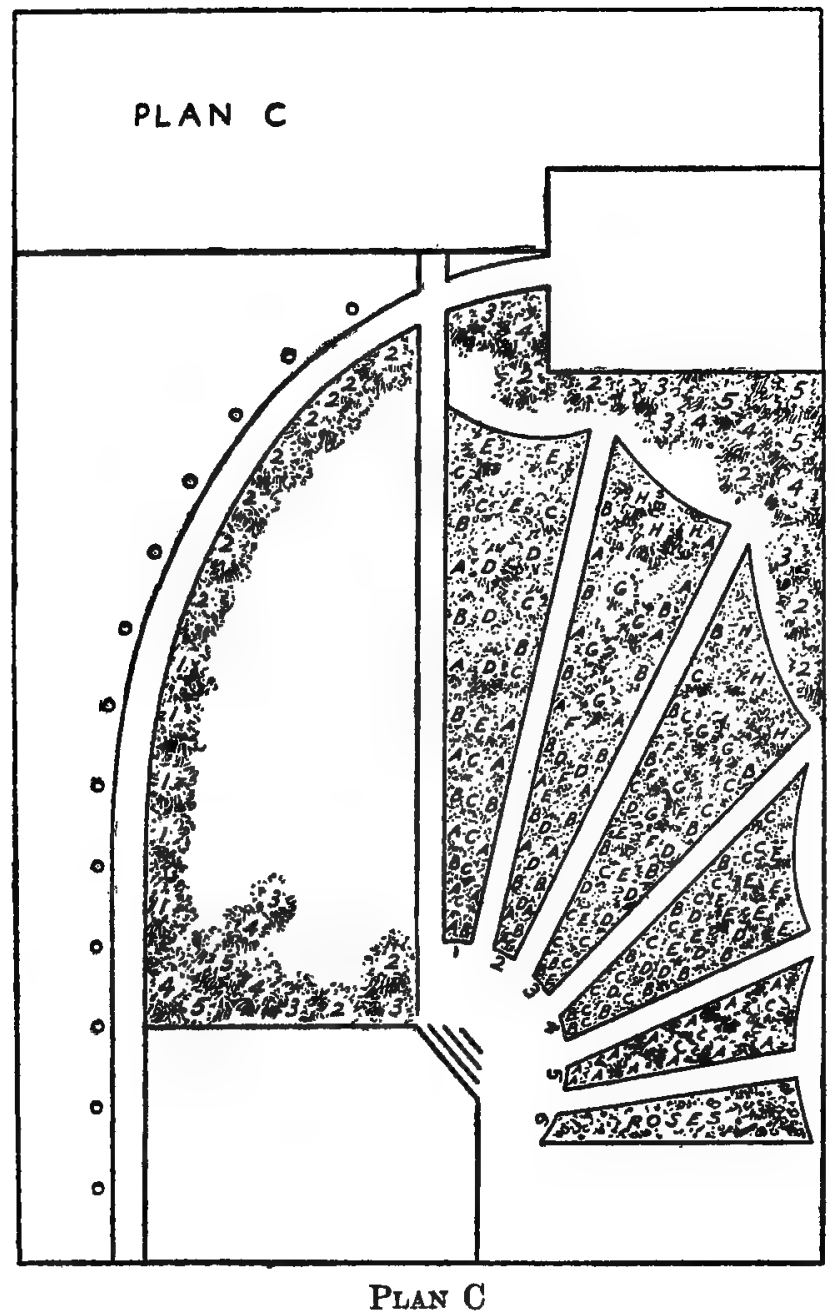




\section{PLAN D}

This plan is adapted to an irregular piece of ground and is especially suited to growing annuals and low-growing plants in the formal beds with tall-growing perennials or shrubbery in the borders at the rear. It will also develop satisfactorily as a plan for a rose garden in which case the central bed may be planted to tree roses or utilized for a rose arbor and in place of the shrubbery in the rear, rose trellises for such climbing roses as Mrs. Robert Peary, Climbing Meteor, Dr. Van Fleet and the like may be substituted.

When used for growing annuals or other plants the central bed is designed for a cement lily-pool, or it may be planted to flowers, but the pool is much to be preferred. Where sufficient ground is at command the design may be repeated by laying out a similar series of beds on the far side of the shrubbery border. This gives a half circle and is a very attractive arrangement. The shrubbery in this case may be planted to pæonies, with good effect, especially if interspersed with quantities of hardy lilies. Boxes of small evergreens or box, placed at the intersection of the paths will be very ornamental. 


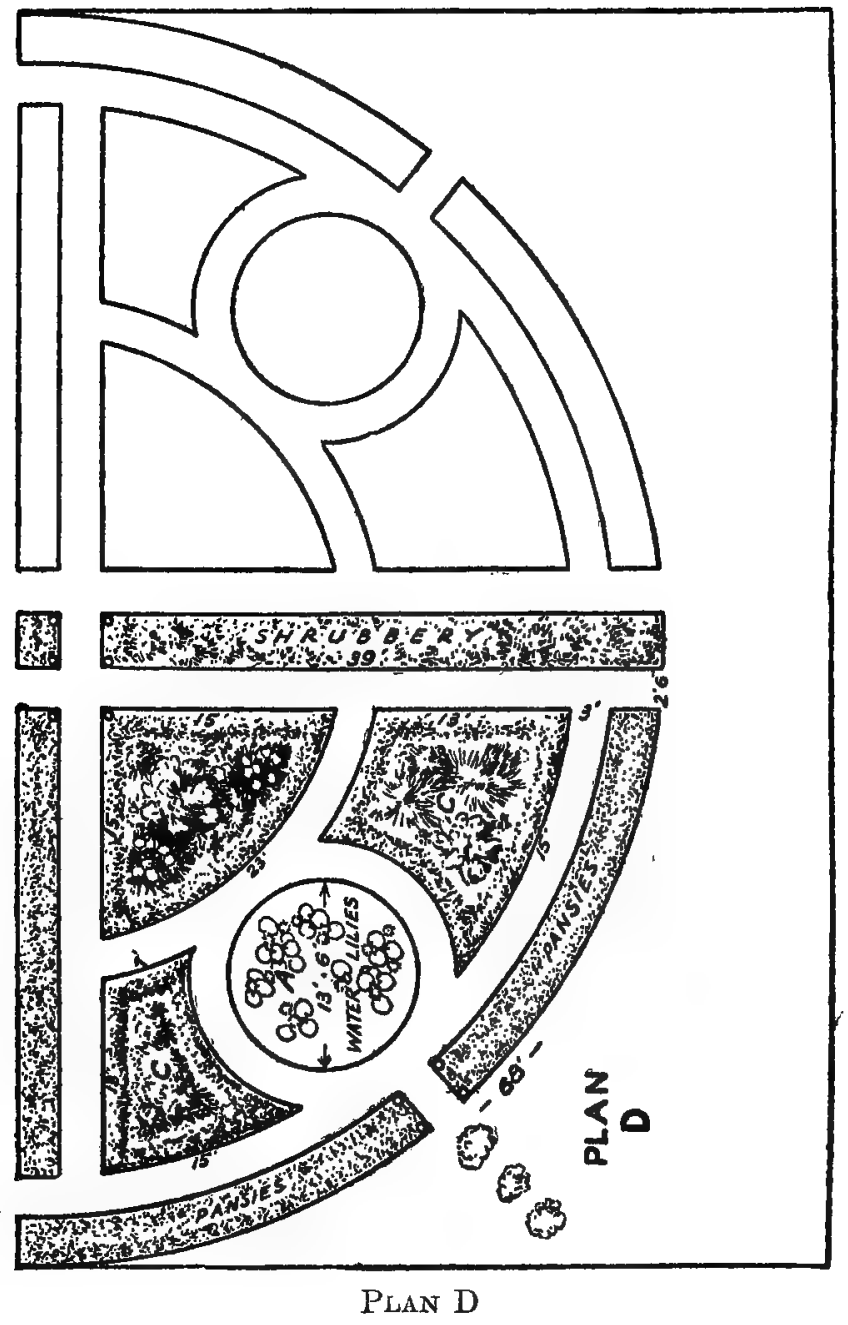




\section{MAKING OF A FLOWER GARDEN}

tern, with brick paths between, are altogether charming in the old-fashioned hardy garden; especially is this true where the enclosing walls are of brick. Paths made from sifted coal ashes, the rough part used as foundation and the white fine ash for surface, are economical, easily cared for and most comfortable to work on-qualities not possessed by brick, cement or gravel. Where the garden is enclosed by a wooden fence of artistic design, painted white, narrow boards also painted white may be used to enclose the beds and will be quaint and old-timey. Whatever the curbing and walls or fences are, the garden accessories should correspond. Brick walls and paths will necessitate garden seats of wood which may be painted a brick red; cement walls call for cement benches, urns, etc., while the artistic wooden fence is best supplemented with garden seats, arches and trellises of wood painted white. 


\title{
CHAPTER II
}

\author{
SOIL AND FERTHIZERS
}

LIKE the making of a garment, the making of a garden is largely a matter of material and style. But while the material of which our garments shall be composed is largely a matter of choice and taste, in the making of a garden we must deal with such material of soil, location and exposure as the good or bad of our environment supplies. Fortunately there is very little in the way of soil that cannot, by proper handling, be induced to respond to culture. I like to think that soil and plants are sentient things, feeling our moods and characteristics much as animals and humans do. If we deal with them generously and sympathetically, they will respond in kind, but the gardener niggardly in care, giving food and seed and moisture with a selfish hand, will reap a barren harvest.

The only soil really unfit for cultivation is one of hard pan. Where this occurs there is really nothing that can be done except to remove it bodily and fill in the excavation with the best soil procurable. A 


\section{MAKING OF A FLOWER GARDEN}

clay soil, on the contrary, is excellent for a rose garden when lightened with well-decayed manure and a proportion of leaf mold and sand; such a soil may need underdrainage of tile or of broken stone and the like, but will not be lacking in fertility.

A too sandy and light soil may be remedied by the addition of manure and leaf mold, or the decayed earth from the compost heap and from decayed sods, and so brought to a high degree of fertility and being light and warm will be in condition to work much earlier in the spring than the colder clay soil. Good loam such as produces a good crop of corn is an excellent foundation for a garden as by the addition of muck and manure it may be adapted to a wide range of plants.

Where a soil is in good mechanical condition, that is, soft and easily worked by the spade and fork, but seems dry and lacking in vitality, the addition of old well-rotted manure in the spring or fresh manure in the fall or late winter will put it in condition for the planting of most garden flowers. The proper proportion of manure is a wheelbarrow load to every square yard of soil. If the manure contains considerable straw, this, decaying, will furnish a certain amount of humus which will counteract the dryness of the soil by retaining the moisture which a sandy soil allows to leach away. Sand forms a perfect drainage table by itself, but when combined with loam 


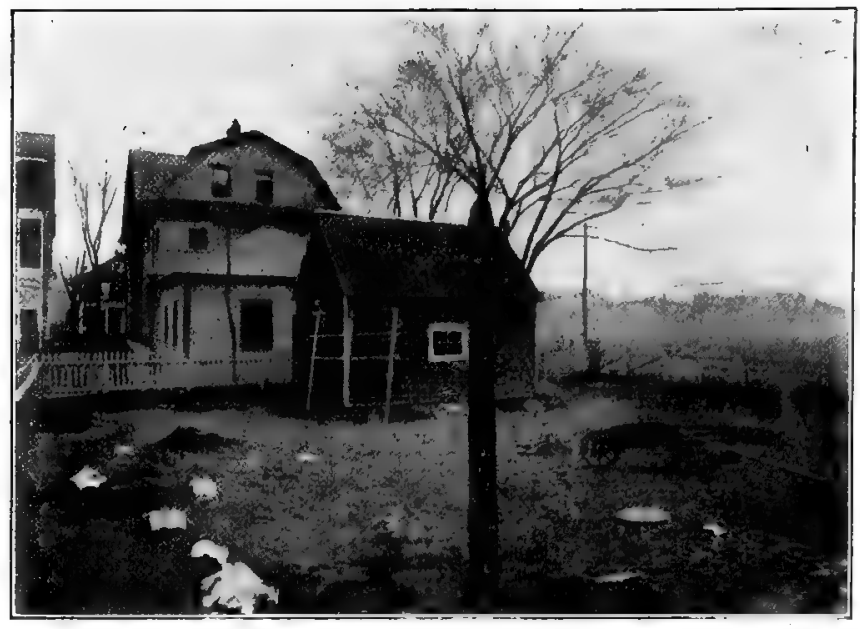

DOES THIS LOOK LIKE A PROMISING GARDEN SPOT?

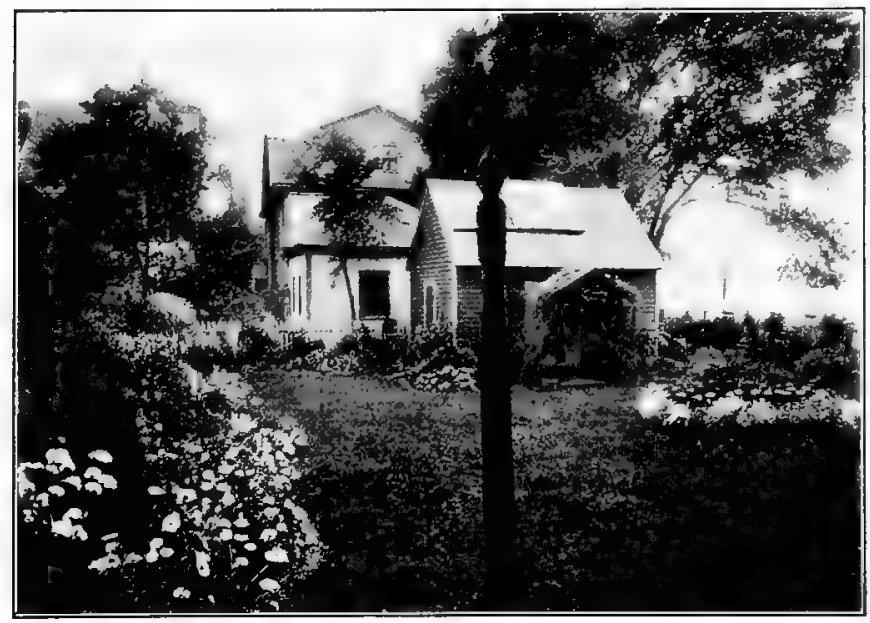

THE RESULT OF A FLOWER LOVER'S WORK IN ONE YEAR 


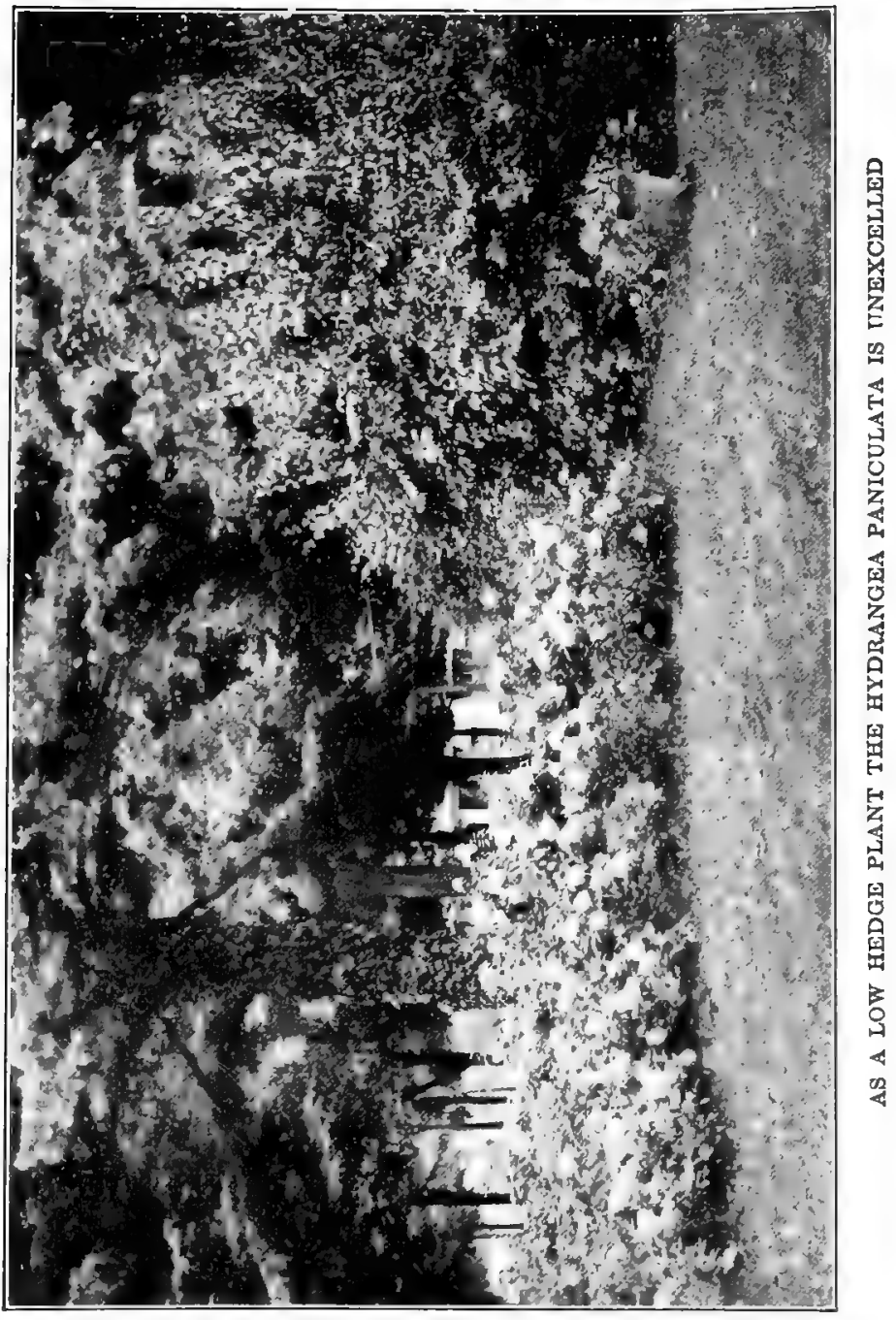


and humus gives the warm, friable condition so necessary to successful plant growth.

In cities it is ofttimes difficult to secure manure, especially old, well-rotted manure, for the garden, but there are few suburban or country places where it may not be had in abundance. Usually its place can be supplied from the various sources of waste fertility on the place. There are very few small town or suburban places in which poultry is not kept by many householders. Now poultry manure is one of the best concentrated fertilizers we have; rich in nitrogen, free from weed-producing seeds and easily stored and handled. If the droppings are removed from the perches daily and stored in barrels, sprinkling a layer of dry earth over each successive layer, it will be in excellent condition to apply to the ground in the spring. The sweepings from the floors should also be saved for the garden, and being mixed with a considerable proportion of straw or other scratch material may be consigned to the compost heap, together with all the rakings from the lawn, the refuse from the garden, garbage from the house-anything of a vegetable nature or that will decay without creating an objectionable odor.

If such a compost heap is arranged in some out of the way corner and kept within bonds by a frame of boards, but open to biddy's activities, it will furnish an inexhaustible source of leaf mold or humus, 
by the use of which, and a little bone meal, one may garden, quite independent of the bulkier manures.

Another source of exceptional fertility is found in night soil that in country places might profitably be returned to the soil with the advantage of greater fertility and better sanitation. If a trench is dug through a garden bed, a foot or two at a time and such matter deposited and covered as soon as the liquid portion has seeped away, the result will be a soil that will grow anything and be in a mechanical condition that makes working it a recreation rather than a toil. One of the finest garden spots I ever saw was produced from indifferent soil by this means alone.

Where poultry manure is used as a fertilizer a much less quantity is required than of stable manure -an eight quart pail full being sufficient for a square yard of ground and this should be trenched in so that the roots of newly planted things will not come into direct contact with it. By trenching is meant the method of laying back the soil across the end of a bed for one spade's depth and width, filling in the trench thus formed with manure and throwing the next row of spading onto this; in this way all the manure is buried a spade's depth below the surface where it remains moist, continues to decay, and attracts the roots of the plants down into deep soil in search of the food it offers. Manure left too close to 
the surface encourages a surface growth of roots that are injured by drought and cultivation.

The droppings from rabbits, Belgian hares and guinea pigs have the same value as the expensive sheep manure for which the florists charge so extravagantly and as it is easily saved and composited with dry earth, or simply dried by spreading out in the open air for a short time, it will form a wellworth considering source of garden fertility. Especially is it suited to the enriching of window boxes and soil in pots. The waste water from the laundry and kitchen is valuable for any part of the garden, but seems especially acceptable to vines, which seldom are surfeited with moisture or food.

Wood ashes are very valuable in the garden, especially on a soil inclined to be wet, cold or sour. They furnish valuable potash and improve the mechanical condition of the soil; they should not, however, be mixed with manure, but rather be used as a supplementary addition, being applied after the ground is plowed or spaded and harrowed or raked in. Application should be made in spring rather than in the fall, while barnyard manure, on the contrary may be advantageously used in fall or early or late winter, especially if new or not well decayed.

Bone meal is another valuable fertilizer and has the advantage of being always available. It does not, however, add humus to the soil and this should, when 


\section{MAKING OF A FLOWER GARDEN}

bone meal is depended upon, be supplied from the compost heap or other source. When using bone meal on beds of hardy perennials, lilies, shrubbery and those plants which, from the nature of their growth are not disturbed annually, but remain for several years where planted, two grades, or more, of bone meal should be used; a fine meal for immediate result and a coarse ground bone for more permanent effect. Even whole bones may be buried among shrubbery and small trees to advantage.

One quart of bone meal to a square yard of ground may be used on strong growing plants, a pint for annuals, while it may be omitted entirely on such plants as thrive best on rather poor soil. 


\section{CHAPTER III}

\section{HOTBEDS}

THE hotbed is so integral a part of the garden that it should precede rather than follow the construction of the garden itself, especially if the laying out of this is left until spring. For, while the ground is still cold with the snow and frosts of winter and the weather offers little inducement to out-door work, the hotbed with its mass of hot manure, underneath its covering of warm, mellow earth, is pushing and coaxing forward, by heat and moisture and sunshineall the potent forces of the still distant summer-the tiny seeds and roots and cuttings entrusted to its care, so that when the beds of the garden shall finally have been spaded and fertilized and raked and nourished by sun and rain and drying winds into just the right condition to receive them, they shall be ready by the dozens and scores and hundreds, to respond to the call for plants and still more plants, for the possibilities of a packet of seeds, sown under favorable conditions, are out of all proportion to their cost. Even the first cost of a really first class hotbed 
may often be met by a single season's production.

Practically all hotbeds are the same in their working, but there is considerable latitude in their construction, especially between the permanent construction of one attached to a permanent home and one of temporary expedience.

For a permanent hotbed there is nothing better than concrete and the expense of this form of construction is not great. For a small garden, including both flowers and vegetables, a bed three feet wide and fifteen long is ample. Florists make their beds much wider, but for the home gardener, especially the woman gardener, a bed three feet across is as wide as can be handled comfortably. The depth-whatever the size of the bed-will be the same, about four feet. In mild climates a more shallow depth will be practicable, but in the colder parts of the country a considerable depth of manure is needed to give the necessary, continuous heat for a period of several weeks.

The simplest way to construct a concrete hotbed is first to mark out on the ground where the hotbed is to be-a warm, southern exposure in the protection of a wall or building and with good natural drainage should be selected and as near the house as possible for convenience in caring for it. Next dig a narrow trench along this outline about four feet in depth and with as smooth and even sides as possible. Into this trench a good quality of grout should be poured and 
the sides paddled, to press back any large stones and fill any hollow places which may oceur. Above the surface of the ground forms will be needed to shape the upper part of the frame which should be a foot high in front and two feet high in the rear, the ends sloping evenly from rear to front. A frame of wood should be fitted to the top of the concrete on which to rest the sash; this may be of two-by-four or two-bysix and should have long spikes driven through at intervals of a foot to bind it to the cement wall. When the cement has thoroughly hardened the inside of the bed may be excavated-care being taken not to injure the cement walls, and the walls given a finishing coat of higher grade concrete.

If a three foot bed is constructed and the regular florist's sashes-three-by-six-are used, it will be necessary to lay them lengthwise of the beds and they may be arranged to slide in grooves, or if the bed is against a wall or building, be fastened to the frame with hinges which will be found very convenient when it must be closed quickly in case of storm' or other emergency. Old window sashes, if well glazed and painted, make excellent hotbed sashes and on some accounts are to be preferred to the longer florist's sash, as they enable one to open a shorter section of the bed at a time, which is often desirable where a variety of plants grow in one bed. Florists usually grow but one kind of plant in a bed; hence all require 


\section{MAKING OF A FLOWER GARDEN}

the same conditions of air and temperature. The home hotbed, on the contrary, contains plants requiring a wide variety of conditions, and partitions between the more delicate and the robust, and small sashes, just suited to their number, will facilitate caring for them.

Concrete has one drawback-it is cold, and I have noticed that the plants close to the frame do not do as well as those farther from its chilling influence. For this reason an interlining of boards, any waste lumber about the place, will be of much assistance in forwarding the growth of the plants. The lumber does not need to be attached to the frame, just stood in place around the inside of the pit. The manure will support the boards sufficiently and it will not be necessary for them to extend above the surface of the soil.

If a temporary, or an inexpensive permanent hotbed is desired it may be constructed from any waste lumber at hand. In this case the pit should be dug the required size and a frame constructed, using four two-by-fours for the corners. The two in the rear should be about six feet long, those for the front corners five. On these corner posts the boards for the lining of the pit are nailed before lowering it into the pit. The height above ground will be the same as the concrete frame. A somewhat cheaper bed can be made by extending the side and end boards only a few inches below the surface of the ground, but this 
construction is not to be recommended, as much damage is frequently caused by moles and field mice finding their way into the bed, a whole planting being often destroyed in a single night. For this reason all knot holes and broken places in the boards should be closed with pieces of tin or wood.

In putting the bed in commission fresh horse manure is necessary; this should be that which has accumulated over night, if possible, for which reason it will be necessary to secure it from a public stable or one where a number of horses are kept. It should be mixed with a considerable amount of bedding or straw, as the burning of this alloy extends the heating period of the manure very materially. The manure alone would give a quick, intense heat soon dissipated.

It is customary for florists and market gardeners to pile the manure in a long pile and wait for it to heat; then fork it over and wait for it to heat again before filling in the pit. This is neither practical nor necessary in the management of a small hotbed; the small amount of manure used would simply dissipate its heat by much handling; the better way is to place it at once in the pit, tramping it down in layers until within a few inches of the level of the ground, care being taken that it is tramped evenly all over, especially in the corners. If this is not done the manure will settle more in one place than another, as fer- 
mentation proceeds, and the earth will crack and sag in places, disturbing the planting.

Over the manure in the bed a layer of an ineh of old, well rotted manure-that from last year's hotbed will answer-should be placed. The object of this is to feed the tender roots of the young plants and prevent their penetrating down into the fresh manure and being burned.

Five or six inches of good mellow soil free from stones, sticks and lumps should be placed on top of this and raked fine and clear; if much rough stuff is present it will be an advantage to sift an inch or two of the top with a sand sieve. If the soil is very dry it will be best to wet it down and wait for it to dry to a moist, mellow condition before planting the seed. Earth that will hold its form when pressed in the hand, but looks mellow and "right" is best.

If the manure is fresh and already heating when applied-and the presence of moisture on the sash will indicate this-the planting of the seed may be started in twenty-four hours. The temperature may also be ascertained by thrusting a fork down into the manure and leaving it a few moments, when the tines, on removing it, will show at once the amount of heat.

In planting seed in hotbeds or other protected places it must be borne in mind that it will not be necessary to plant as deeply as in the open, unprotected ground. Conditions of heat and moisture be- 
ing under control, more shallow planting may be practiced which will make a few days' gain in time of germination. There is one similarity, however, in all planting-the earth should be pressed firmly over the seed. The reason is this: when the seed germinates it sends out a little shoot with tiny, very tiny, little feelers on the end; now if this shoot in emerging finds itself in a little depression between two grains of earth-a cavity too small to be noticeable to the eye-it may not in those first critical moments of infantile life be able to connect itself with the atoms of earth on which its sustenance depends, for that little hole in the earth may prove a big and lonesome chamber to the little rootlet, across which it may not be able to creep in time. But if the earth is fine and soft and pressed snugly about each little seed there will be no disastrous spaces to cause decay.

A piece of flat board with a handle on one face is a very handy tool to use in planting the hotbed. This will press the earth down evenly and is much better than the hand as it does not leave depressions in the ground to hold moisture and occasionally cause the fatal damping off so destructive to plant life.

In planting the hotbed the seeds should be classified, planting, as far as passible, those requiring the same degrees of heat and air and moisture in the same section of the hotbed. Plants which make a tall, vigor. ous growth from the start should be planted in the 


\section{8}

MAKING OF A FLOWER GARDEN

rear of the bed in order that they may not overshadow the lower growths. Cosmos, gourds and Cobaea scandens are a few of the plants that should be relegated to the rear.

Plant each variety of seed either in long rows across the bed, especially those seeds that are sown in drills, or in little squares by themselves, separating each square or section by narrow strips of wood pressed into the ground. This prevents the seed of one plat washing into the next if too much water happens to be received at a time; it is also of much advantage when the time comes to transplant the plants to the garden, especially in the case of several colors of the same plant-as in the case of asters, which would be difficult to distinguish, but you will know, by the dividing strip of wood, that all on one side are white, on another pink, and so on.

Very fine seed like begonias, carnations, etc., should not be planted directly in the ground of the hotbed, but rather in shallow boxes-codfish boxes and half size cigar boxes are about right-and these set on the surface of the soil; other fine seed may be sown broadcast over the surface of the soil, pressed down with the board and then be covered lightly with fine sand sifted over. Somewhat coarser seed may be sown on the surface and have an eighth of an inch of fine earth sifted over; other seed may be sown in shallow drills and the earth pressed back over it and quite 
large seeds should be sown their depth below the surface. All bean-like seeds should be planted with the eye down; Cobaea scandens and gourd seed should be set on edge; planted flat they are quite apt to decay, rather than germinate. As a Japanese friend said, "They are very corruptible."

Each variety of seed should be plainly labeled with wooden labels, with both the name and date of planting and, if known, the period of germination. This last is a most important memoranda as it advises when the plants in a particular plat should appear. Without it one is quite apt to expect results too soon, to become discouraged and to commence digging up the ground to see if the seed has sprouted-a performance not at all conducive to successful germination. There is a wide divergence in the germinating period of various seeds; some, especially many annuals, germinate in from three to five days, others from five to eight and so on up to the slower growing gourds and hard-seeded plants which require from twelve to fifteen days. But this is by no means the limit of seed dilatoriness, some seeds requiring a year to germinate. These, obviously, should not be planted in the hotbed, but rather in a protected bed in the open ground, or in a coldframe.

When the planting of the hotbed or any one section of it is completed it should be sprayed carefully with a fine-rosed watering pot and covered with news- 
papers and the sash closed until such time as the plants appear, when the papers should be removed and replaced on top of the glass directly above the plants and the sash slightly raised to admit air.

Air is very necessary to plant growth and one should aim to give as much as possible without chilling the plants. On sunny days the sash can be raised from the start a few inches if the precaution is taken to throw a rug over the opening of the sash on the windward side and to close the sash as soon as the sun has left it. It is equally important to raise it as soon as the sun raises the temperature inside suffciently, as the heat increases very rapidly under glass under a direct sun, and it requires but a brief season of too high temperature to lay low an entire planting of seed, some plants being especially susceptible to burning.

The hotbed should not be allowed to dry out or be kept too wet. It is best, usually, to water in the morning, unless very dry at night and the weather promises to be dry; a good wetting at night followed by a stormy day or several days necessitating the closing of the bed may spell disaster, for there is no way of drying out a bed in wet weather.

Protection will be needed on stormy days and nights. For this there is nothing so good as straw mats. Failing these, old carpet makes a warm covering, especially if protected by a canvas cover to shed rain. A 
strip of canvas large enough to cover the entire bed and extend down the sides, and coated with preservative paint or oil, is an excellent investment, as it can be used spring and winter. If the corners are mitred or folded and secured with loops to fasten them about the frame so that they cannot be blown away, one can tuck away the hotbeds on the stormiest nights with no fear of frost.

It is rarely expedient to start the hotbed before the frost is out of the ground. Taking into consideration the time in which the slowest seed will germinatesay two weeks-and allowing six weeks more for the plants to have attained suffieient size for transplanting into the open ground after danger of frost is passed (which each one will know in his particular latitude), it will be a simple matter to decide just when the beds should be started; it may be February in the vicinity of Philadelphia or further south, or late March or April in Miehigan where we often find April 1st quite early enough. But north or south, east or west, it will be six or eight weeks before " corn planting time."

When all the plants are up and growing, lath screens over the sash during the hottest part of the day will be of benefit, especially as the weather grows warmer. Later these may be replaced by screens of wire if it is necessary to protect the beds against chickens, cats and other predatory attacks. Full ex- 


\section{MAKING OF A FLOWER GARDEN}

posure to sun and air is best after the plants have made some growth, providing there is no hint of frost in the air. While the beds should never be allowed to suffer from drought it will be best to let them dry out occasionally, sufficiently to harden the plants and encourage a stockier, woodier growth of stock and branch. If there is room to transplant the plants in the bed or one has auxiliary beds in which they can be transferred, much benefit will accrue, especially to such plants as asters, balsams, cabbage, cauliflowers and the like, though most plants recover quickly from the effects of crowding if the transplanting is judiciously done.

Especial care should be given to hardening off the plants for a few days preceding transplanting, both by withholding water and by giving full exposure to the weather; but the night before actual transference begins the bed should be well soaked to enable the plants to store up a generous supply of moisture to serve them until the roots have recovered from the shock of transplanting and are ready to resume the work of extracting moisture from the soil.

It goes without saying that the beds should be in complete readiness for receiving the plants, and this preparation should have been made several days in advance of transplanting and before a soaking rain if possible. Newly spaded and worked ground is in too light and porous a condition for the setting of plants 
or the sowing of seed; it should have time to settle and become close and firm but not hard.

Where plants are to be set in straight rows, as in borders or in square beds it will be best to draw lines for the regular setting either by the aid of a garden line or by the use of a board. Where square beds are to be planted the use of a board is a great help as it gives a place to stand or kneel without treading on the bed and the space at which the plants should be set can be marked on the edge of the board with chalk, thus enabling one to work rapidly and accurately. If the board is the width of the space between the rows so much the better as it needs only to be moved its own width to mark the new line of plants.

Only as many plants should be lifted at one time as can be gotten into the ground before they wilt. In lifting the plants press the trowel well down below the roots and lift a bunch of plants at a time, do not separate the plants until you are ready to plant them, and then carefully, one at a time. Make for each plant a hole with the trowel large enough to receive the roots without crowding, place the plant in position and draw about the roots part of the displaced earth, pressing it firmly down and about the stem; pour in sufficient water to fill the hole; wait for it to seep away and then fill in the remainder of the soil. Do not press this down hard, but make it level, dry and fine above the roots. All the holes of 


\section{MAKING OF A FLOWER GARDEN}

a row may be dug at first; then the plants set and the water placed in each and the covering done last; this makes the work go off more quickly as there is then no waiting for the water to soak away. After.all the plants are in, go over the bed carefully and see if any wet spots appear; if this is the case dry earth should be drawn over them. This dry mulch is the important point in transplanting; if the roots are well wet down and then protected with a dry mulch of soil there will be no check in the growth of the plant and practically no loss in transplanting. The dust mulch keeps the soil and water underneath cool and prevents its drying out. If the surface soil were allowed to remain wet, the water would be all drawn to the surface by the action of the sun and the capillary action of the soil; also the sun penetrating the open pores of the soil would heat the water, injuring the roots. Under the action of a wet soil and hot day, plants unprotected by a dust mulch are literally cooked to death. For this reason it will be readily understood that the beds should not be watered after planting, but should be left undisturbed for several days or until they show by the action of the plants that root growth is established. Should any plant show signs of wilting or of needing water it should be supplied by making a hole at one side of the plant, applying water and replacing the dry mulch. No protection of any kind should be given newly set 
plants unless protection from frost is required by a fall in temperature, and to avoid this it is better not to be in too much haste to set out plants, for it is far easier to protect plants in a compact mass in a hotbed than when distributed over several hundred feet of outdoor planting.

Should a rain follow a planting and this be followed by sunshine, the beds should be gone over as soon as practicable to restore the dust mulch. A season of clear, bright weather is always best for transplanting; hot, muggy weather with frequent showers followed by hot sun the very worst, but a spell of wet weather with a grey sky is a very good condition, as there will be no steaming of the plants under those cireumstances.

It is a good plan to keep back a part of the plants in the initial planting so as to have a reserve to call on in case of accident to those already planted; especially is this desirable in the case of vegetable plants from which the cut worm takes so large an annual toll. Cosmos, gourds, and succulent stemmed plants are especially desired by the little brown and red worms that hide away so coyly in the daytime and work such havoe at night. Gourds, especially, should be protected by a collar of stiff paper or tin. Tin cans with the bottoms removed may be pressed into the ground around the plants, half the tin being beneath 


\section{MAKING OF A FLOWER GARDEN}

the surface, care being taken to see that no worms are included in the enclosure.

This having a reserve of plants is the strongest argument for the possession of a hotbed. Often in bad years, having sufficient plants to replace those destroyed by cut worms, without the expense of purchasing the same, will more than meet the initial expense of a bed. They always pay for the annual upkeep. In bad years it is no unusual thing to have to replant three and even four times, hunting for and killing the worms, morning after morning, before freedom from their depredations is secured. Especially is this true when a garden borders on new sod or clover land which harbors an endless hoard of worms. 


\section{CHAPTER IV}

COLDFRAMES, FLATS, AND OPEN GROUND PLANTING

A COLDFRAMe is a supplemental hotbed without the heat. Not requiring heating material it is not necessary that a pit be dug for it-the part of the frame of the hotbed which extends above the ground illustrating the construction of the coldframe. A bed may be dug and shaped the size the coldframe is desired to be, just as one would proceed with a flower bed in the open ground. The coldframe is then placed over this and a sash provided and such heat as it requires will be supplied by the sun's rays shining on the glass which should usually face the south. If it is desired to use the frame in early spring, late fall, or winter, extra protection can be afforded by banking up about the outside of the frame with earth, sods or manure and providing mats or canvas for the top.

A coldframe is a very useful adjunct of the garden as it furnishes a safe place for the growing of perennials for the coming season's use, especially those varieties whose slow germination unfits them for sow$37 ;$ 
ing in the hotbed or in the open border. It is also of prime importance where crowded conditions in the hotbed make transplanting into temporary quarters desirable. If half the plants can be lifted and set a couple of inches apart in a coldframe the advantage is evident.

For temporary uses like this, a very good constructive arrangement of a coldframe is to have the frame fastened together with pins or bolts so that it can be taken apart when no longer needed.

A spent hotbed furnishes a most excellent coldframe as the soil is rich in plant food, but has the objection of being needed before the ground is ready to receive the plants that must be disturbed; a coldframe solves this difficulty as they may be put into it temporarily. Pansies should always be started in coldframes if wanted for early spring blooming, though these can usually go into the open ground as soon as it can be worked in the spring.

For the early starting of seeds where neither a hotbed or coldframe is available, flats in the house offer an excellent substitute. Wherever a warm, sunny window-preferably a south or an east one, is available, excellent results will follow indoor culture. Shallow boxes-not over five inches deep for the large growths and two for fine, greenhouse plants, of any convenient size should be chosen. Boxes narrow enough to rest on the window sill, or better still, a 
broad shelf under a window that will allow of the boxes being drawn away from the glass, are more convenient to handle, and like a hotbed, several kinds of seeds may be sown in a single box providing they have similar requirements of heat, moisture and air. A box fashioned after the manner of a hotbed-high in the rear and low in front and supplied with a glass -makes a miniature greenhouse, will be found very satisfactory and can be easily constructed by any one handy with saw and hammer.

Codfish boxes and shallow cigar boxes make excellent flats for the finer class of seeds-carnations, heliotropes, begonias, cinerarias, gloxinias, cyclamen, all may be grown successfully in these. A few holes should be made in the bottom of the flats to furnish drainage and these should be covered with bits of glass or shard and a little fine sphagum moss scattered over the bottom of the box for drainage before putting in the soil. The best soil for flats is a compost of good garden loam or fibrous soil from the bottom of sods, mixed with a little leaf mold and clean white sand, thoroughly incorporated; with this the larger flats should be filled to within an inch of the top, the smaller flats to a half inch. The earth must be settled evenly and pressed off level with a bit of board or anything handy-a paper weight is a good tool to use. Such fine seed as begonias, gloxinias and the like should be sifted as thinly as possible over the 


\section{MAKING OF A FLOWER GARDEN}

surface of the soil, pressed down but not covered, unless with a light sifting of fine white sand, scarcely enough to cover the ground. Sand is better than soil for this purpose as it reacts against the tendency to produce the damping off fungus so troublesome in house culture.

Larger seed may be covered with a light layer of soil, still larger planted in drills and covered once their width in depth.

All flats or sections of seeds should be carefully labeled with name and date of sowing. After the seed is planted the small flats should be set in a pan of luke-warm water until the surface appears dark but not wet; the larger flats may be watered with a fine-rose or a rubber sprinkler, taking care not to wash the seeds loose from the soil. Cover the flats with white paper, over which lay a glass and give a position of as uniform heat as possible. No light will be needed until the seeds have germinated when the plants may be removed to a warm, light window and the paper removed, but placed between the box and the window glass, and the glass slightly raised; increasing the light and air as the plants will bear it. A width of cheese cloth stretched across the window will temper the light sufficiently for most plants.

Plants grown in flats in the house require rather more attention than in a hotbed, as they are more tender, lacking the bracing out-door air. If the win- 
dow can be raised a little while every day, care being taken that there is no direct wind across the flats, it will help materially until such time as the sash can be raised most of the day. The boxes must not be allowed to dry out, as the earth is very shallow in these little receptacles, nor must it be kept too wet or soggy; just a mellow, moist, growing condition must be maintained. Other treatment and requirèments are the same as in hotbed culture.

Sowing seed in the open ground is usually a very satisfactory way of dealing with those plants which do not require an early start. Nearly all annuals may be started outdoors, but should be planted deeper than in a flat or hotbed and the earth firmed well above them. If the season is that of the early spring rains, there will be no need of protection but should the season be dry it will be best to give protection of a little lawn clipping, or a little brush to prevent too much drying of the soil. This should be removed after the sun has left the bed in order that it may have the benefit of the night dew. After the plants are up no shade will, usually, be needed unless the position is very arid and exposed. Frequent watering with a fine sprinkler will be needed if the season is dry and as soon as the plants are large enough to handle it will be necessary to thin considerably, especially if they are to remain where planted-as is true in the case of annual poppies. These should be thin- 
ned to stand from nine inches to a foot or more apart according to the variety. Plants which will stand transplanting may be lifted and planted elsewhere.

Seeds of hardy perennials may be sown in the open ground and allowed to remain until fall or even the following spring; if planted in May no protection will be needed, but if planted in August it will be well to protect the planting with lath screens raised a foot from the ground. A very excellent way of starting hardy perennial seed is to sow it in long rows through the vegetable garden and give exactly the same treatment as that accorded the beets or other vegetables, thinning the plants when up and cultivating throughout the summer. In the fall they may be lifted and planted where they are to remain, or they may remain where planted until the following spring, protecting the plants, if of a character which is benefited by protection, by boards leaning against stakes driven into the ground between the plants, or by evergreen boughs laid over them, or better still, leaning against a pole attached to stakes driven between the rows. The evergreen branches should be set tips downward so as to shed rain and wet. Pansies, hollyhocks, garden pinks and all plants which retain a crown of leaves during winter are especially favored by this form of protection.

In planting seed of annual poppies, forgloves, sweet alyssum and the like it is only necessary to scatter 
the seed broadeast and either press it into the soil with a board or, if the earth is dry, to rake it in and then tramp it firmly with the feet. As poppy seed is very fine and the work of thinning the plants considerable, it is a good plan to mix the seed with dry sand-about a cupful of sand to a packet of seed and to broadcast this as thinly as possible.

Closely connected with the preparation of the ground and the use of fertilizers, is the selection and use of tools. It is impossible to work a garden with any degree of comfort and success without the assistance of suitable tools. At the same time, a multiplicity of tools is apt to prove "an embarrassment of riches," so large a number of the gardening tools upon the market are manufactured to sell and to tempt out of the pocket of the amateur, that slippery American dollar, which is never so elusive as when one begins to dabble in soil and the things which pertain thereto.

Such tools, however, as are essential should be of the best quality and suited to the hand of the one who is to use them. A good spade, with the blade at the angle most convenient to use-some prefer a straight handle, while others can work better with one which throws the point of the spade out-and a step wide enough for a good foot-hold, is the first tool which will be needed. Following this, a good iron rake of the curved tooth variety, or a lawn rake may be used 


\section{MAKING OF A FLOWER GARDEN}

very conveniently if preferred; a hoe of small blade and light handle, suitable for chopping in between plants of perennials and shrubs, and a trowel. This should be of steel in one piece-no riveted handle sort should be invested in-and it will be well to purchase three or four trowels and keep them in different parts of the garden, as they are apt to be needed when not available and the extra steps required in running after them often result in a bit of work being neglected that would be done were the means of attending to it at hand when it was noticed. Also it will be found a wise precaution to tie a bit of bright ribbon to the handle of each trowel, as there is no garden tool so prone to loss and to being covered up with the soil and weeds as this, and the bit of bright color helps to identify it.

Where the garden is planted in long even rows and the plants set a reasonable distance-fifteen to eighteen inches-apart, the use of a hand cultivator of the Planet, Jr., type is possible and will so simplify the work of caring for the garden that twice the amount of space may be undertaken; the use of the cultivator produces a far thriftier growth of plants, but where the garden is laid out in formal beds it is not practicable and one must use the hoe and spading fork more or less. After the beds have been spaded up in the spring and put in thorough order it will not be necessary to do much deep digging, but rather 
to keep the soil soft and open by maintaining a dust mulch.

The best tool for this purpose and for all-around work in the garden is the scuffle hoe. This tool's flat blade, about nine inches wide and four inches deep, is set at an angle of about thirty degrees to the handle. In using it is pushed from one, stirring or scuffling the earth and producing a dry mulch of from one to three inches in depth according to the angle at which the handle is held and the vigor with which it is used. As there are no projections or parts to catch on the plants it can be pushed close to the stems and under the leaves without in the least disturbing them. In using, the worker walks backwards, thus avoiding the tramping on the newly worked ground as is necessary with all other forms of cultivators. I know of no other tool or combination of tools with which one can accomplish the same amount of work with so little fatigue. By going over the garden with it the morning after a rain, a dust mulch is established which will, ordinarily, carry the garden on to the next rainfall. Its use in the eradication of weeds in the garden is invaluable. By going over the ground as soon as the first seed leaves of the weeds appear one can keep the garden entirely free from weeds the entire season with no more trouble than is required to maintain a dust mulch. In fact, with this tool there is no excuse for weeds. 


\section{MAKING OF A FLOWER GARDEN}

Another tool which will be needed in spring and fall is a good garden line and reel. This may be easily manufactured at home or may be bought at a reasonable price of any dealer in garden supplies. For laying out round beds and similar work a garden pole, instead of line, will be useful. This is easily made by drilling holes six inches and a foot apart in a strip of inch lumber about two inches wide. At one end there should be a larger hole into which a stout, pointed stake with a shoulder is inserted so as to turn easily and the top of the stake should have a peg or nail in the end to prevent its dropping out. A sharp, somewhat slimmer peg or several of these, should be provided to fit the smaller holes which are used for measuring. By using a tool like this it is possible to mark off a garden like the circular rose garden in Plan D or Plan C at almost one operation, by using a long enough pole and from four to fire pegs.

A carrier in which plants may be transferred from the sandbox to the garden or house will be found of use and a very convenient one may be made by taking a straight piece of board about twelve inches wide and eighteen or twenty long and nailing strips of wood about three inches wide along the sides and fitting a handle, which may be improvised from a barrel hoop soaked until pliable and nailed exactly in the middle of each side of the board so that it 
will hang evenly when loaded. A watering pot, a hose and nozzle and plenty of wire and lath screens, twine or raffia for tying, labels and stakes for staking plants about complete the sum of the necessary garden tools. 


\section{CHAPTER $\nabla$ \\ THE ANNUAL GARDEN}

THE annual garden may be said to be the inception of the garden proper. It is the first word in garden culture for the majority of people; for many it is the only word, as it may be written in colors of flame and pencils of light across the transient way of the peripatetic wanderer from one brief camping ground to another farther on when the "wanderlust" calls.

The permanent garden shares the dignity of old established homes and traditions; it suggests quiet streets and deep, well cared for grounds, sloping away into generous distances, but the annual garden may be a little patch of bloom beside the door or down the path to the gate; it may be but a bit of ground reclaimed from the ash pile and rubbish heap of a city back yard, but it will be none the less lavish of bloom and fragrance for its sordid surroundings, nor the less beautiful when surrounded by well kept lawns and shrubbery.

The speed with which an anncal garden may be brought into bloom-a brief ten weeks from the first 


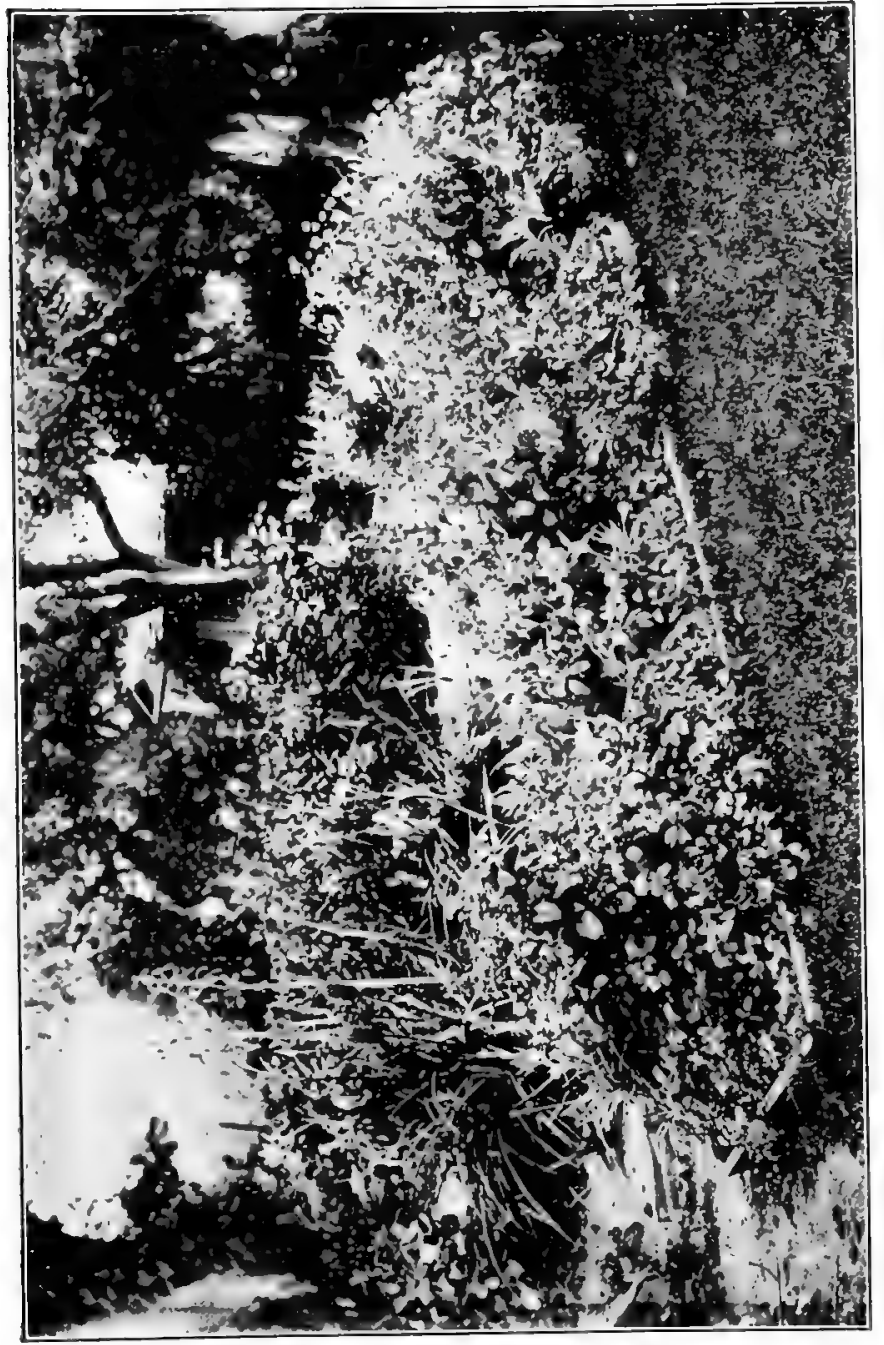

告 


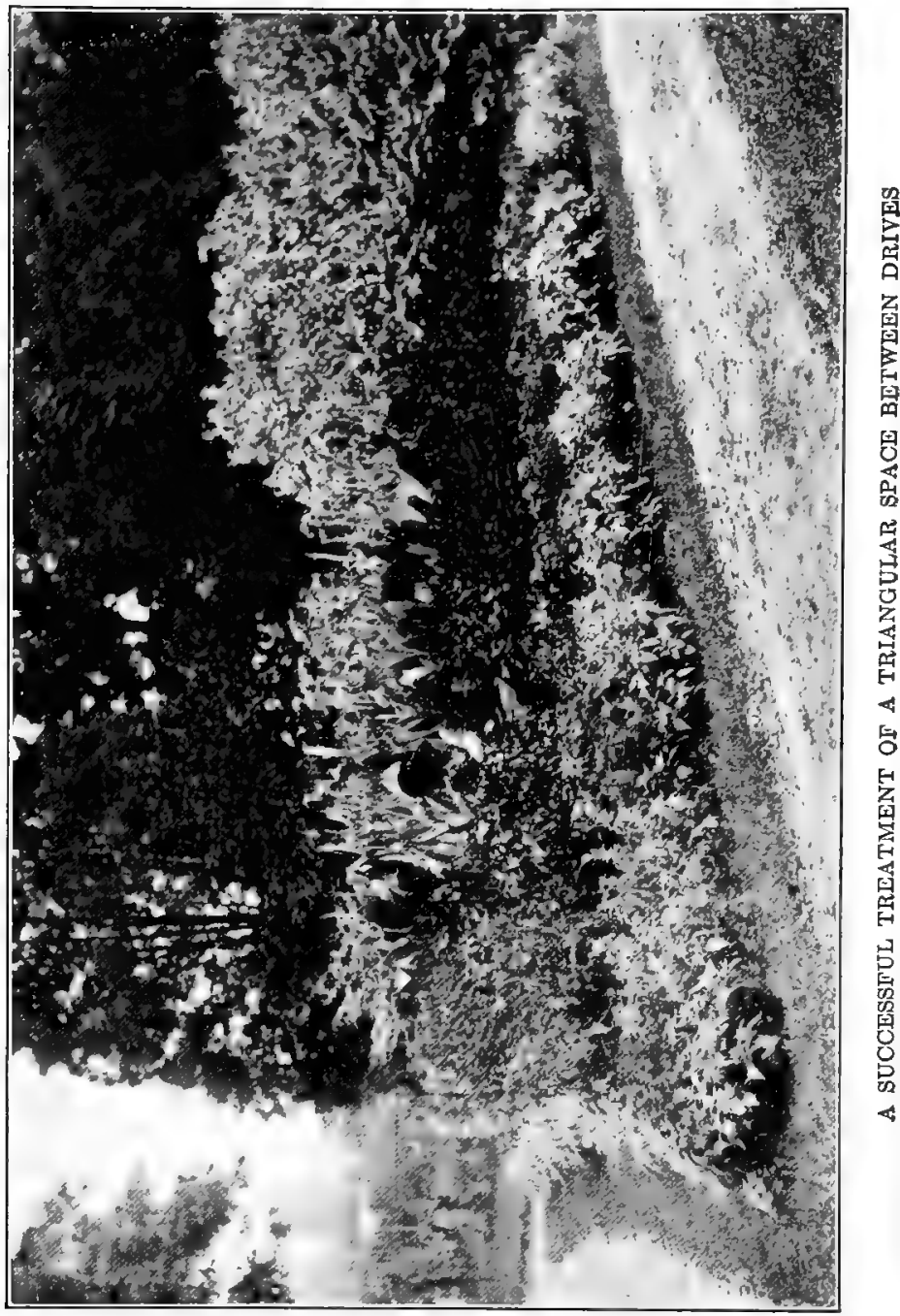


breaking of the sod, to a riot of color-gives it an importance second to no phase of garden culture. If a permanent, hardy garden is in contemplation, and it is desired to proceed economically and conservatively by growing one's own plants from seed-which may be done by the hundreds at a cost of the same plants by dozens from the florists-then the use of annuals to fill the beds until the perennials are ready is invaluable as the seed may be sown broadeast in the beds in April or May, according to the latitude, and thinned or transplanted in May to give abundant room for growth, and the first year of the garden may have no embarrassing hiatus of bloom, but be a sheet of beauty from early summer to frost; for all annuals lend themselves remarkably well to mass bedding, especially where grown one variety of flower in a bed. It rarely pays to mix annuals in formal beds, though that may be done with good effect in borders along the foundations of the house, along the fence or drive or other informal positions; even then it is best to colonize each variety by itself, alternating the clumps if .desired, or planting low-growing sorts in front of taller growths.

Many of our ornamental bedding plants may be raised from seed and treated as annuals. Especially is this true of the tuberous sorts, as the cannas and dahlias, coleus and salvias, which are usually bought of the florists, may be easily started in hotbed or 
house and bedded out when all danger of frost is past, and a few cents' worth of seed will give several dollars' worth of plants, which will give quite an air to the lawn and garden. Ricinus or castor bean, one of the most imposing ornamental plants we have, is so easily grown from seed that its use should be more in evidence, especially in these sections of the cities or towns where lots are still divided from each other by unsightly fences and the rear of the lots defined by alleys. Here the ricinus may be very useful in hiding all that is unsightly and obtrusive, and this is true of many of the taller growing annuals-the Cleome pungens, annual sunflowers, cosmos, euphorbias, Nicotiana sylvestris and the like-while for low beds about the house or lawn there is nothing better than the brilliant verbena, the persistent petunia, which comes in so many beautiful shades and colorings and blooms until real cold weather, or the Phlox Drummondi.

Indeed, there is scarcely a need of the flower garden, except that of permanence, that may not be met by an excursion into the realm of annual flowers, and the requirements for their growth are of the simplest -just fairly good garden soil, worked fine and mellow and enriched with some old, well-decayed manure and, if possible, some leaf mold or earth from a compost heap, and a sufficient supply of water during the growing season, especially when the flowers are 
developing, for annuals do not have the root system possessed by the long-lived perennials and shrubs. Bone meal is a good fertilizer for annuals, and a little nitrate of soda worked into the soil about the plants after they are up and have been cultivated once, will hasten them along wonderfully sometimes, but should not be used on those few plants that do best in rather poor soil, like the nasturtium, which, given too much food, produces a rank growth of leaves at the expense of blossoms.

Tall hedges, low hedges, screens, massed bedding, ribbon bedding, vines for all positions-porches, pergolas, trellises, vases, window and porch boxes, hanging baskets and the like-may all be recruited from the useful annual roster.

Annuals are especially useful in filling in beds or edgings planted to spring blooming bulbs-tulips, hyacinths and the like-especially where it is not desired to lift these when their season of bloom is past. A light scattering of seed of any low-growing, or slender annual-one that does not make a suffciently strong root growth to interfere with the welfare of the bulbs, such as petunias, verbenas, asters, phlox, lobelias, the dwarf morning glories and any number of other flowers-will keep that portion of the garden in full bloom for the remainder of the season.

Better still, plants of such annuals as it is desired 
to use may be started in the hotbed or flats in the house so as to be ready to plant out as soon as the tulip or other bulbs have ceased blooming; in this way they will be ready to furnish bloom much more quickly than if planted in the open ground. Candytuift is one of the annuals that comes into bloom very quickly, but as it gives but one florescence, repeated sowings of seed should be made, the second about the time buds begin to show on the first plants; in this way a succession of this most desirable plant will be assured. The schizanthus is another desirable plant, repeated sowings of which are necessary for a succession of bloom. These little plants, with their exquisite mass of flowers of all delicate shades of white, pink, rose, mauve and the like, come into bloom very soon after growth begins, and present a perfect pyramid of bloom, each plant a symmetrical bouquet, perfect, complete, but the first florescence is practically all there is of it so that successive sowings should be made if one desires a mass of continuous bloom.

One of the plants which requires a little special treatment is the scabiosa. This for best results should be started early in hotbed or flats, and transplanted out as soon as danger of frost is past, so that it may come into bloom before hot weather, as it is not at its best in extreme heat. It is one of our most beautiful annuals, and the range of color is unusual, white, flesh-pink, rose, terra cotta, crimson, purple- 
black, azure-all beautiful and distinctive. As the scabiosa has little foliage it should be massed rather closely, and the tall stems will be the better for some support, as slender bamboos or strings drawn across the beds to which the stems may be secured, but as inconspicuously as possible. The scabiosa is one of our very best cut flowers, remaining fresh in water a considerable time and the buds opening well.

Cosmos is another annual which should be started under heat early, and transplanted when the nights and ground are warm. It should have a warm, sunny situation and abundant room-not less than three feet between plants, and five would be better. Give rich soil, stake with a sturdy stake at least five feet long and driven well into the ground, for the cosmos is badly twisted and broken by high winds, and when once down cannot well be raised again, but is then better allowed to lie on the ground, where each branch will root at the joint and grow erect from that point, making a fine and sturdy clump. They make an excellent boundary line between the vegetable and flower garden or other part of the grounds, and do exceedingly well where they can have the cultivation given the vegetables.

Verbena seed will germinate much more quickly if soaked in quite warm water over night, and seed of the annual morning glories, especially the Japanese variety, should be soaked in warm water until they 
sprout, and then planted in warm soil in a sunny situation. Or if this is not convenient and it is preferred to plant direct in the open ground after the nights and soil are warm, then they should be dropped thinly in a shallow drill and hot water poured over them before filling in the earth; this will make several days' difference in the germination period.

Asters will make much finer plants if transplanted once at least before being set where they are to grow, and balsams will not give the fine, double blossoms desired if they are not transplanted once at least. On the other hand, some annuals will not bear transplanting at all, so must be sown where they are to bloom, as the various annual poppies. The perennial forms, however, transplant readily.

In planting canna, the seed, which is very hard, should have a hole filed or sandpapered on one side and then be soaked in hot water until the inner shell bursts. It should then be planted in pots, plunged into the hotbed or a box of sand in a warm window and grown until time to plant out where it is to remain. Re-pot if the plant requires it. Many annuals are greatly benefited by the use of marsh earth or muck in the bed. Especially is this the case with the salvia, which grows to unguessed proportions under this stimulus. This, if old, may be spread over the beds and spaded in, but if fresh a hole should be 
dug, filled with it and covered with earth and tine salvia, canna, etc., set in it. Little, if any, trace of the muck will remain when the plant has completed its season growth.

The accompanying list of annual plants is merely suggestive, as there is not room to list the various members of each plant family, but any good catalogue will supply such additional data as may be desired. 


\begin{tabular}{|c|c|}
\hline 蓦 & 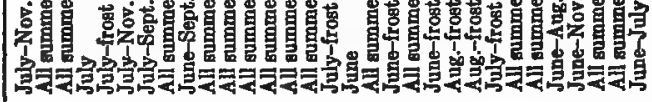 \\
\hline$\frac{8}{8}$ & 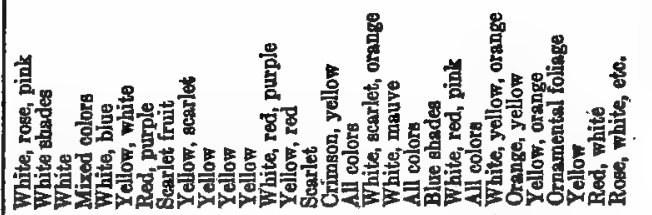 \\
\hline 跑 & 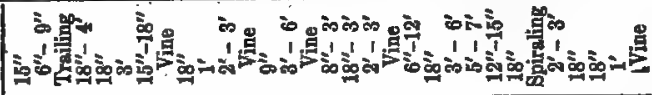 \\
\hline 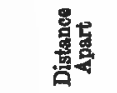 & 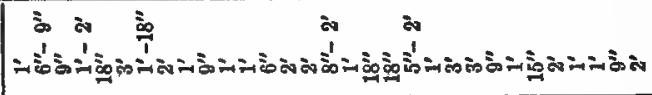 \\
\hline 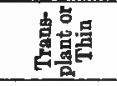 & 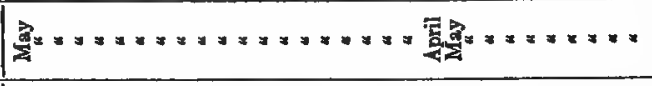 \\
\hline 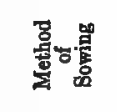 & 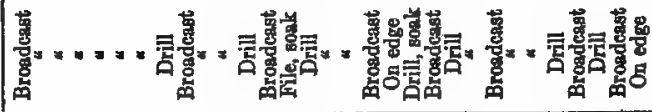 \\
\hline 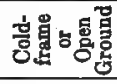 & 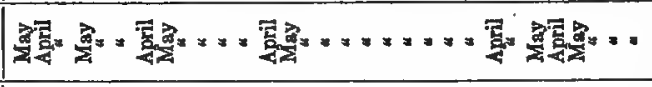 \\
\hline 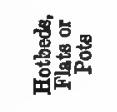 & 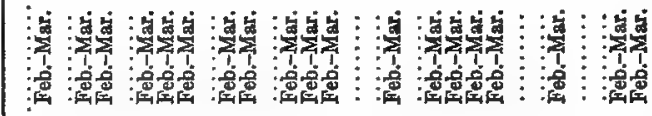 \\
\hline 8 & 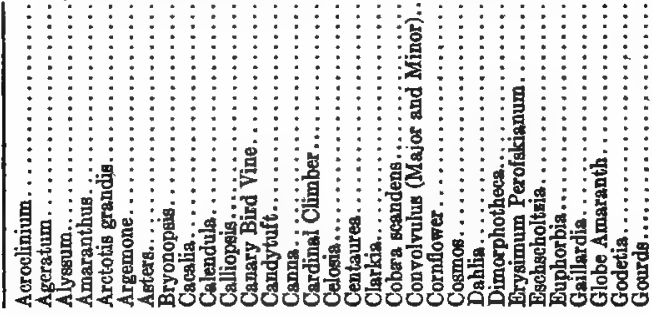 \\
\hline
\end{tabular}


THE ANNUAL GARDEN

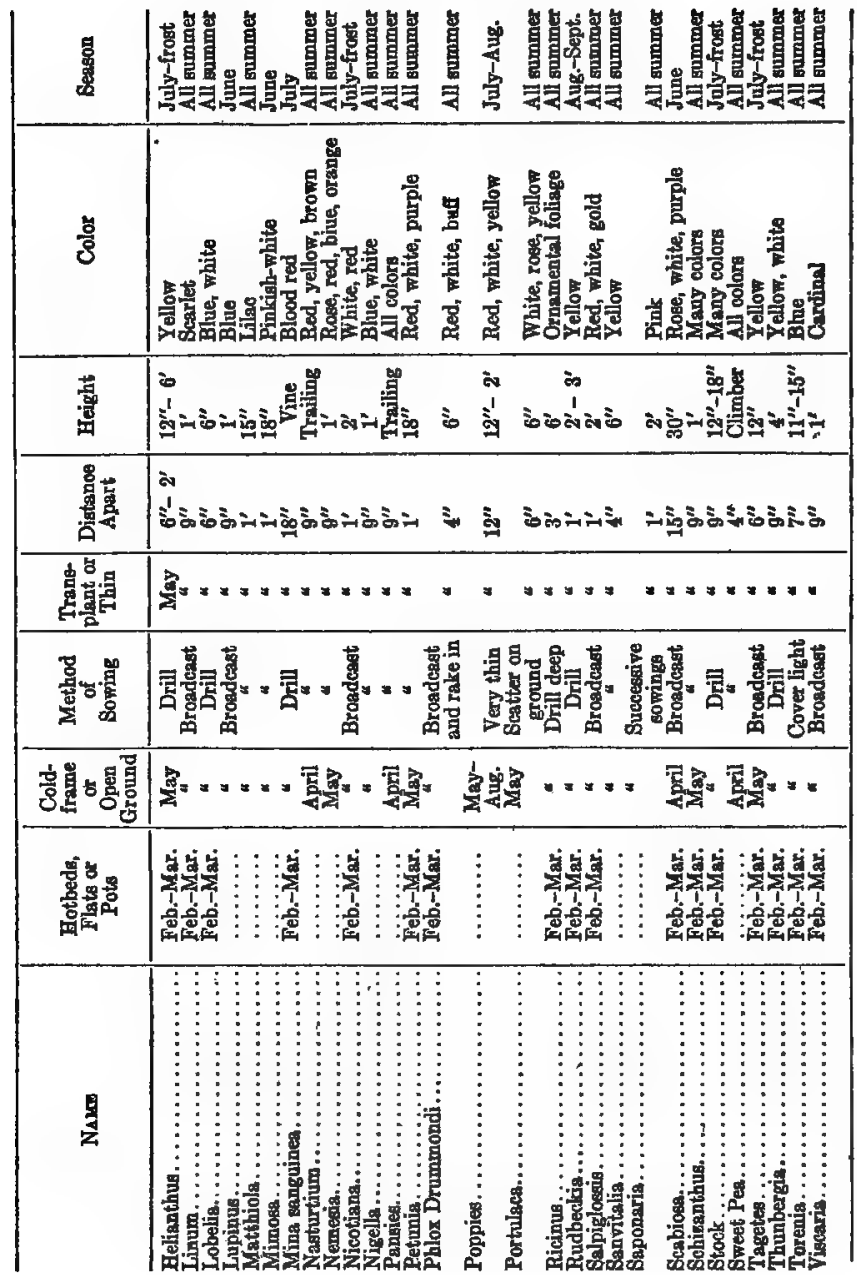




\section{CHAPTER VI}

BEDDING PLANTS FROM SEED

A VERY decided saving in the season's outlay for the garden can be made by growing one's own bedding plants from seed. Many of the bedding plants purchased from the florists are quite as easily grown from seed as from cuttings, and will usually make a more vigorous growth than when subjected to the change from a heated greenhouse to the open ground. At any rate, the saving in expense is well worth considering, as a hundred plants may be raised from seed for what one would pay for a dozen pot plants.

Coleus is easily raised from seed sown in hotbed or flats, the seed germinating quickly and the plants growing finely from the start. A good many new shades and markings may be expected, and as the plants will be showing individuality by the time they should go into permanent beds, one can readily select those which most appeal to one, and discard the undesirable ones. No special care is required in sowing the seed. Cover an eighth of an inch deep, pressing the soil firmly above it, water carefully, 
cover with a white paper and glass until the plants appear, then place in a warm sunny window, shading the glare of the sun for the first few days with a bit of cheese cloth stretched across the window, then give full sun as the plants grow in size, for coleus depends upon the sun for the beauty of its foliage. Transplant, when large enough to handle, into similar flats or small thumb pots, if the number is not too large, plunging these into boxes of moist sand or moss and grow until planting time. The directions for coleus seed apply equally well to all the smaller seeded plants with the exception of heliotrope. Where these are required for bedding, extra care must be given to the question of humidity, as they are very sensitive to extremes of drought or dampness and must be kept just at the point of drying out, but never allowed to do so, for success.

Salvias are, of all bedding plants, the most easily managed; the seed, which should be sown in flats or hotbed, germinates in from three to five days, and all the little plants ask is a chance to grow in sunshine and fresh air in abundance, but not cold air, as the salvia is a plant of warmth and sunshine, especially in its early stages. Grown from seed they bloom earlier than from cuttings, and I have had from spring-sown seeds plants five or six feet high and a mass of bloom by mid-summer.

Dahlias are as easily grown from seed as salvias, 
but should be planted in the hotbed or flat and kept warm and not planted out until the ground is warm - probably the first of June in the north. The single dahlias are especially satisfactory when grown from seed, and make excellent cut flowers, especially for corsage wear.

Asparagus Sprengeri is so easily raised from seed that one should use it much more than is done, as nothing quite takes its place for window and porch boxes.

Begonia is another easily raised bedding plant; the seed of this being very fine should be sown on the surface of the soil in small flats, the seed being merely pressed into the soil and the young plants must not be exposed to extremes of temperature or moisture, and must be transplanted as soon as large enough to handle, into other flats, setting them an inch apart each way.

Cannas, especially the ornamental-foliaged varieties, are very readily raised from seed, which should be first sandpapered on one side till the white shows through, then soaked in hot water till the inner shell cracks, and planted two or three in a four-inch pot, and when a few inches high all but the best one should be removed. Give air, sunshine and abundance of water at all times, and transplant into the open ground when all danger of frost is past, setting from one foot to eighteen inches apart each way. 
The zonale geraniums are of the easiest culture and should be handled the same as salvias, dahlias and the like-gentle heat, sun as they grow stronger, but less water than cannas and a little hardening off before transplanting.

Lantanas are especially easy to grow ánd make delightfoul low hedges between lots or between different parts of the grounds where a low hedge is desired. Each little seed is a nut in reality and, curiously enough, will often give two plants from one nut. They grow very rapidly, and I have had, from spring planted seed, plants over two feet in diameter and a mass of bloom by mid-summer. They do not seem to be afflicted with insects or disease, and are altogether one of our most desirable bedding or pot plants.

The lobelia is so easily grown from seed that it may be used to edge beds of other plants as well as for vases, boxes, baskets and the like.

Petunias are so desirable in all the many varieties that one can never go far amiss in planting them largely, both for mass effect on the lawn, for edging to the perennial borders or in front of shrubbery, or for window and porch boxes and for vases. The small flowered white snowball is one of the best for mass effect. The brilliant, and equally effective, carmine variety, and the Howard Star are also desirable in this respect, Brilliant being a very effective variety for massing in window boxes 
where a mass of solid color is desired. But for perfection and size of bloom there is nothing to equal the single, large flowering petunias, the Giants of California and the Ruffled Giants. These should be found indispensable to every complete flower garden. But if one desires to grow notable flowers of these giant strains one must be sure that the seed purchased is the best obtainable and to insure this one must pay a price that will guarantee it, certainly not less than twenty-five cents a packet, and give the seed a little extra care, planting it in shallow flats set in the warm greenhouse, hotbed or a warm window, and not allow them to suffer from too dry or too wet a soil or too hot a sun, or the lack of it. Prick out the little seedlings as soon as large enough to handle, into other flats, setting them an inch or more apart each way and transplant again when they begin to crowd. Do not discard the tiny, weak ones, as these are quite often the choicer sorts, but when the plants are a few inches high and long before they begin to show buds the superior sorts are easily distinguished by the stockier branches and heavier, curlier leaves-indeed there is as much difference between the plants of the large flowering sorts and the common small bedding plants as there is between the flowers.

A very satisfactory and rather uncommon bedding plant which from its many good qualities and ease of culture should be more in evidence in our gar- 
dens, is the vinca, or Madagascar perriwinkle. They make neat, erect plants from twelve to fifteen inches in height; the foliage is dark green, glossy and entirely free from insect pests. The flowers, five petaled and star shaped, are produced in the greatest profusion from August until frost, and if lifted and potted will continue to bloom indoors all winter. There are three varieties, a rosy crimson with dark eye, white with erimson eye and pure white, all equally good. The seed requires heat to germinate, so should be sown in the hotbed or flats and given the same general treatment as other bedding plants.

The ricinus is too well known to require special instructions for its culture, but best results are secured by planting the seed in pots and transferring the plants to the open ground when the soil and nights are warm. When disturbed in transplanting they are sometimes very slow in taking a start, but grow vigorously when once under way, and it is rarely that a plant is lost. The zanzabariensis variety is the finest for general culture, but where a high screen is desired, rather than a fine foliage effect, some of the taller sorts may be employed.

Some of the vines usually purchased of the florists for vases, window boxes, trellises and the like are as easily grown from seed as any of the common garden annuals. Cobaea scandens is a case in point; all that is necessary being to start in hotbed or flat, setting 


\section{MAKING OF A FLOWER GARDEN}

the seeds on edge and covering a fourth of an inch with mellow soil. These are most desirable, both as climbers and as a source of cut flowers, for the plants commence blooming early and bloom every step of the way, from the ground up to the topmost branch, which is often an incredible distance from the ground. I have had them flaunt their pale green, lavender, mauve and wine-colored bloom from the tipmost branch of a tall pear tree, or from the top of a windmill tower.

The dainty little manetta vine is easily grown from seed, as is also its sturdier neighbor, the thunbergia, with its disc-shaped flowers of white with black eye, yellow with black eye and pure yellow. Kennilworth ivy grows readily from seed and self-sown plants of this and manetta vine are often found the following year under the boxes where they bloomed and seeded the year before. The ivy loves to creep into the crevices of the stone or brick foundations of the house, even creeping through the windows and growing luxuriantly in the earth inside. Under one window in an earth fruit cellar the soil was green all winter with this delicate vine, which looked far too delicate to withstand the cold of its curiously chosen home. 


\section{CHAPTER VII}

\section{BULBS FOR SUMMER BLOOMING}

OF special interest to the summer garden, especially in the summer or the temporary home, is the class of plants known as summer-blooming bulbs, though some of them belong properly to the tuberous and corm class, as the dahlia, canna and the like: They have one general classification, however, in that they are bedded out in spring or early summer and depend upon house or cellar storage during the winter, in this being differentiated from those bulbs and roots which remain for the entire twelve months in the ground.

The most conspicuous member of this class, used as it is so largely for ornamental planting in parks, on lawns and wherever a semi-tropical, ornate effect is desired, is the canna. This, while easily raised from seed, is usually started from the tubers which have been wintered in the cellar or purchased of the florist in the spring. Where cannas are grown for the bloom as well as for the foliage effect the planting of tubers is really necessary, as only in this way 
can reliable varieties be secured. Of late years great improvement has been made in the size of bloom, the coloring and the abundance of bloom so that the canna can no longer be regarded merely as an ornamental foliage plant. The tubers can be started in house or hotbed any time after the first of February. As cannas are very susceptible to decay, the earlier they can be started, all other conditions being favorable, the better. The bunch of tubers should be carefully looked over, giving one good eye to each piece, and removing all decayed or shriveled parts. They may be started in pots of soil, in boxes of sand or in baskets of moss, either medium giving excellent results; the moss (Sphagnum) has much to recommend it, as it is light and clean to handle. Very little is to be gained by too early planting in the open as, while they are less tender than some of the other summer bedders, still they will succumb to a late frost, and the labor of covering them nights and removing the cover each morning offsets the small advantage gained in time. Cannas are gross feeders and quite intemperate in the matter of drink, and they should be planted, therefore, in very rich soil-manure and marsh earth suit them admirably-and never allowed to suffer for water. If one has not city water or a water system on the place, then it will be well to plant the cannas within easy reach of such water supply as exists. The plants should be set from eighteen inches to two 
feet apart, according to variety and the effect desired.

Dahlias, while not enjoying the place in landscape gardening held by the canna, are magnificent when grown as a hedge or background for smaller plants. The flowers, indeed, leave little to be desired in effectiveness of size and color, and the many forms produced meet the requirements of a wide diversity of tastes. For cut flowers and corsage wear, the single blossoms are more graceful and desirable, but for unique beauty and quaintness there is nothing to equal the cactus type-they are my especial favorites of all the dahlia family, especially the glowing cardinal varieties. Unlike the canna, the dahlia winters admirably and need not be hurried into growth in the spring. Usually they will announce their readiness to grow by throwing out lush green shoots while still in the dark corner of a cool cellar. Like the canna they may be started in earth, in sand or in moss, or they may be held back (and this is the better way) and planted directly where they are to bloom when the soil is warm-about the first of June in the north. In separating give each tuber a live shoot and a portion of the old stock. Tubers having no live eye or shoot will not produce one, but may be used to graft a live shoot on if there are more than one shoot to other tubers and it is desired to produce as many plants as possible. Remove a shoot close to the tuber, cut the end to a wedge, cut a corresponding wedge- 
shaped piece from the tuber it is desired to use and insert the shoot; place in the ground and draw the earth up firmly about the shoot; it will make as good a plant as though grown from the tuber in the original way.

Dahlias require rich soil and abundance of water, especially when producing their flowers. They. also require very substantial support, as they are easily broken by wind, and even by a heavy rainfall when in full foliage. A five-foot stake is none too long, and a six-foot one still better, and it should be stout in proportion and firmly set in the ground. It is well to set the stake at the same time, or soon after the plant is set, as the dahlia makes a whorl of big fleshy tubers, and if one waits until the stake is needed it will be difficult to set it close enough to the plant to support it without injuring the roots; when set with the plant, tying can commence as soon a,s the plant is a foot or more high, and proceed as growth progresses.

A mulch of old manure or lawn clippings about the plants after they have set their buds will be of much benefit, especially if the plants are where they will not be disturbed by chickens scratching the mulch off the ground. Lawn clippings make an ideal mulch when undisturbed, and should be placed four inches deep to start with and added to as they wither. If left undisturbed they will settle into a close mat 
that will keep the ground moist, mellow and free from weeds; stirred up, they are of little benefit.

But if one wishes to grow dahlias for cut flowers and wishes to produce notable blooms that will make the professional florists sit up and take notice, he should start the tubers in the open ground about the middle of May, making a big, deep hole and laying the tuber, live eye up, therein at a depth of about four inches and cover with not more than two inches of soil at the start, adding the remainder as the plant increases is size, for too deep covering of the tuber at the start is the cause of much failure in dahlia culture. And the planting should not be in formal beds in the garden, but down in the vegetable garden where they can receive the same cultivation given the corn, for that is just the sort of care the dahlia thrives under, and not any exotic, professional treatment; just plain, everyday garden culture, with a horse cultivator if passible or a hand cultivator if the garden is small. This and plenty of water will give the best that can be produced in this magnificent class of plants.

The dahlia has its enemies, though some years they are little in evidence, and these are less troublesome in open-field culture than in the flower garden. The aphis, or green $\mathrm{fly}$, is often in evidence, but can usually be controlled by an emulsion of tobacco stems in water or tobacco soap, sprayed on the plants; an 
even better spray is clear hot water at about a hundred and forty degrees, or water at a hundred and thirty degrees may be used in a large vessel and the tips of the branches-the most affected parts-dipped in it and held there for one minute. The Green Leaf Hlopper is more troublesome owing to its penchant for moving around just when one most wishes it to keep still. It is of all insect pests the most troublesome to eradicate, but can be handled very early in the morning while the foliage is wet and the insect sluggish, by spraying with the tobacco or soap solution.

Gladiolas offer as few problems for successful growth as one could reasonably expect of a flower; a warm, sunny position, well enriched soil, either from a liberal fall application of manure to the bed or a spring dressing of sheep manure or the droppings from the rabbit warrens (which may well be composited during winter for this purpose), applied in the spring. The bulbs should be prepared for planting by removing the dried skins and the dead root at the base of the bulb. Large bulbs may be planted from six to eight inches deep, small bulbs more shal. low, but the deep-planted bulbs can go into the ground earlier and remain later, and will require less staking than the shallow-planted ones. If one wishes a succession of bloom successive plantings of 
bulbs will insure it, making the plantings every two weeks up to the first of July.

Gladiolas are very satisfactory for cutting, as they may be brought in when the first flower has developed and every bud will unfold, often seeming finer than those in the open ground. Especially is this the case in extremely hot weather, when the blooms fade quickly.

For mass planting a large number of bulbs of one variety is best, or one may plant two or more varieties that contrast effectively, as the blue or violet Baron Hulot and the yellow Sulphur King. One of the best bedders of the red class is found in Mrs. Francis King. This is a light scarlet or flame color, and is an excellent cut-flower variety, selling well to the stores in the cities. It is also very moderate in price, the bulbs selling for something like two dollars and a half a thundred, or five cents each singly. The pure white varieties are always lovely, and some of them reasonable in price, so that they may be planted in masses, and in combination with the scarlet sorts are very effective. Augusta is a lovely, pure white variety with blue anthers, and Glory of Holland another beautiful sort, the anthers in this being violet instead of blue. Both of these can be purchased for fifty cents a dozen, and much cheaper in larger quantities. Most of the other white varieties show a slight penciling or suffusion of color. 
There are some very rich, dark gladiolas in the newer sorts well worth cultivating, Deuil de Carnot, Europa, and Empress of India being especially desirable sorts.

Caladiums form an important part of the summer's ornamental planting. No other plant equals them in foliage effect. The immense, glaucus green leaves often measuring three feet or more in length by two or more wide, have a lush, tropical effect distinctly their own. The plant is a gross feeder and heavy drinker, and must have an unlimited water supply to be at its best. If one can procure marsh earth for the caladium bed it will well repay one to do so; marsh earth that has been thrown up in ditching and lain over winter for the action of the frost to subdue it is of course best, but where this is not obtainable the fresh muck from the swamp will be equally acceptable to the caladium, but must be buried under the garden soil as, left exposed to the air and sun, it becomes simply a piece of peat, more suitable for fuel than for plant food. Caladium tubers may be planted directly in the open ground, about the first of June, or may better be started in the hotbed in March and planted out the first week in June. Set the tubers three feet apart at the least, so that they may have abundant room to develop the massive leaves. If the bed is slightly lower than the surrounding lawn it will be all the better, as it will retain moisture to a greater degree than a raised or level bed which allows much 
of the water to drain away. Thorough spraying of the leaves in dry weather is absolutely necessary if the bed is to present an attractive appearance, for the leaves collect and retain the dust to a surprising degree, but are easily cleansed by the hose or watering pot.

The fancy leaved caladiums are exquisitely beautiful miniature plants more suitable for indoor culture than for bedding out, but may be used in porch or window boxes in favorable situations. They require a. lighter soil than the Caladium esculentum, woods earth and fine white sand and the fibrous soil from the under side of sod furnishing an ideal compost. They require heat in starting and water should be given sparingly until growth is well under way, when a liberal supply may be furmished. For pot culture in the house or conservatory during the summer months they are ideal and should be largely employed to replace the bedding plants which will be removed from the conservatory or house at the approach of warm weather. Three or four in a large pot will give a rich and charming effect, or they may be grown in window boxes very satisfactorily. In autumn, when they show signs of resting, water should be gradually withheld, and the pots stored in a dry, frost-proof cellar-a furnace cellar if possible.

Tuberous begonias have come into wide popularity during the past few years, and few, if any, plants 


\section{MAKING OF A FLOWER GARDEN}

surpass them in charm and beauty. They are especilly adapted to growing in east window boxes and in sheltered spots on the lawn. They require the same quality of soil as the fancy-leaved caladiums-leaf mold, sand and fibrous loam and practically the same conditions of moisture when starting growth, but somewhat less when growing. A good method of start-

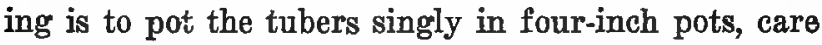
being taken that they are planted right side up, as there is little difference apparent between the crown and the root side until growth starts, and when there is any doubt at all about the matter it will be best to start the roots in damp moss placed in a shallow box or basket, where the tubers can be spread out side by side and kept just moist, until there is suffcient sign of growth to make planting safe. They may then be potted and allowed to grow until time to plant in permanent beds or boxes. Plant rather shallow, not more than an inch in depth, water sparingly until growth begins, and be sure that good drainage is provided to care for any surplus moisture.

Tuberous begonias may be wintered in the pots in which they were grown, allowing the soil to become quite dry, and storing them in a cool but frost-proof closet, or they may be lifted and each tuber wrapped in waxed paper and stored in a drawer in a cool room. Tuberous begonias that have been grown in the open 


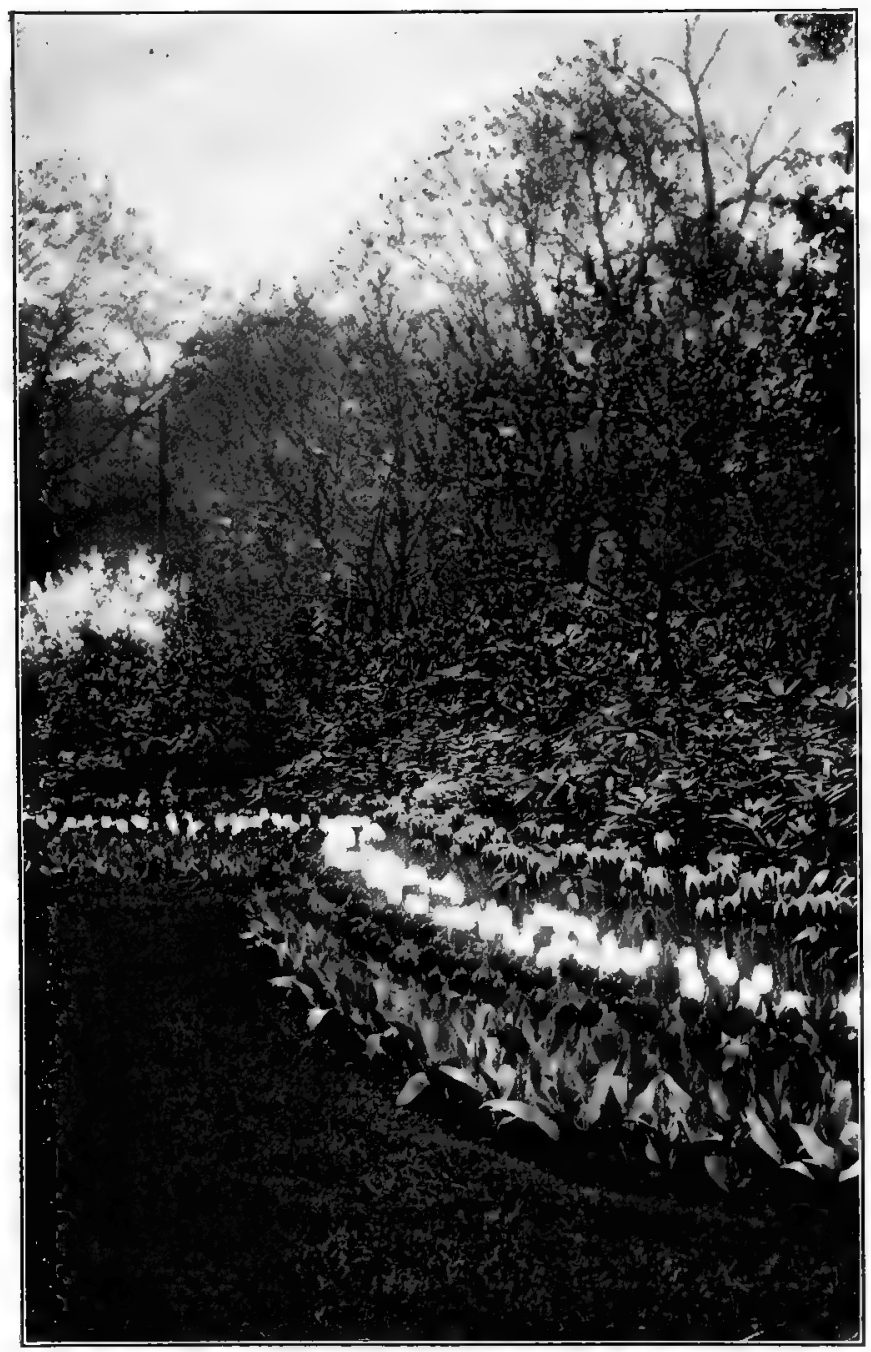

RED AND WHITE TULIPS USED AS A BORDER FOR SHRUBBERY 


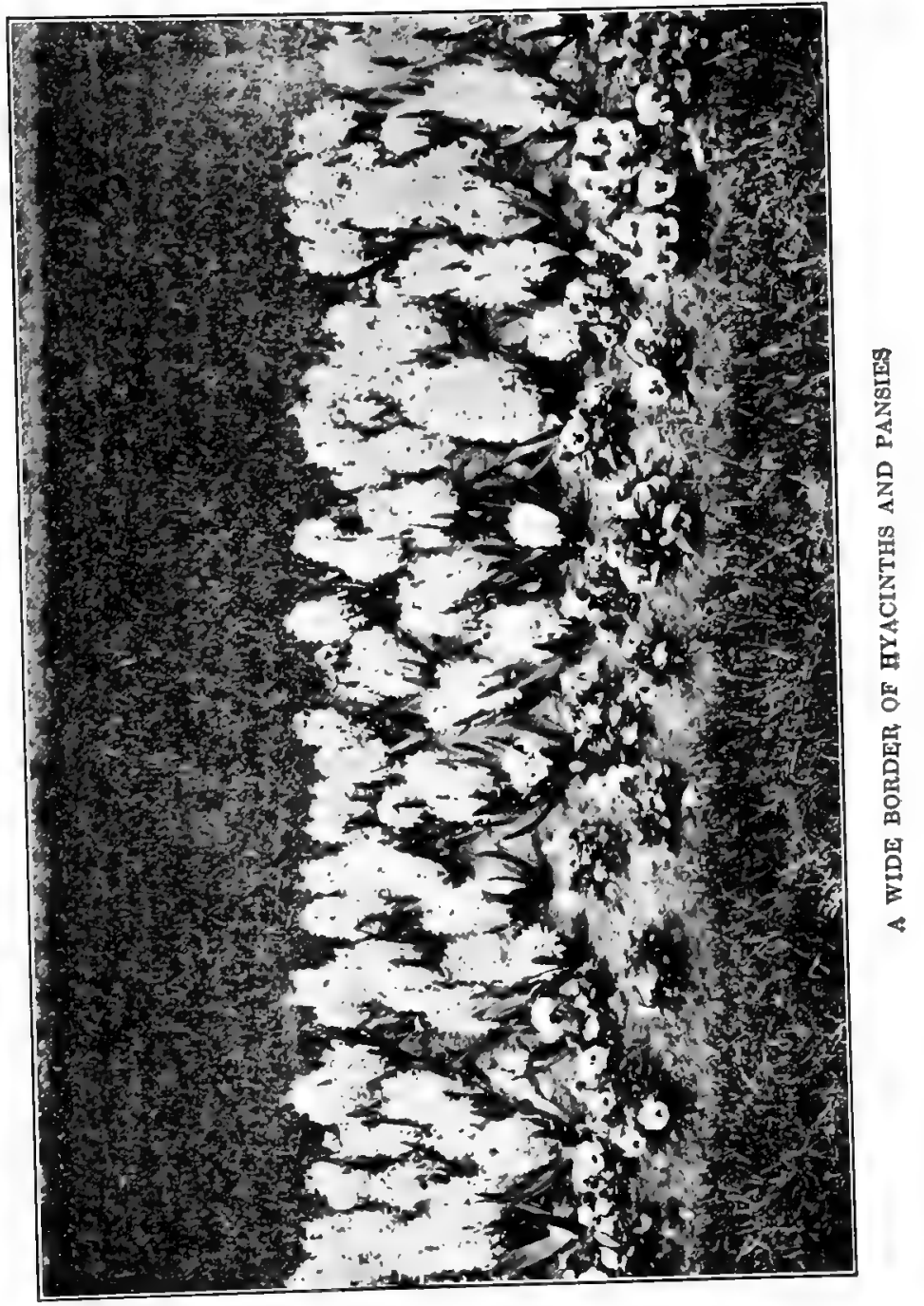


ground must, of course, be lifted, dried and wrapped in paper or stored in boxes of dry sand.

Ismene calathina is a delightfully scented, distinctive summer flowering bulb, unique in form and color; the beautiful amaryllis-like blossoms are of the purest, most glistening white, while the throat is green and the anthers spring from the angle of the petals instead of from the spadix in the center of the flower. The leaves are broad and strap like and of themselves form a distinctive and imposing plant. They require warmth in starting and may be potted in the house or plunged in the hotbed until time to plant out in the open ground, about the first of June. Any good garden soil will grow them successfully and a sheltered, sunny position on the east or south will be favorable. In the fall before the frost has killed the foliage the bulbs may be lifted and potted and, after a few weeks' rest, be again started into growth for winter blooming or the bulbs may be wintered in a warm cellar until time to start into growth another season. In storing in the cellar they should be placed in boxes of dry earth to prevent shrivelling.

The Ismene is beautiful in front of beds of taller growth, especially where they furnish a green background which increases the apparent purity of the large white flowers. The odor is so delightful that it, alone, would furnish a motive for the culture of this exquisite summer flowering bulb. 
Montbretias require the same general treatment as gladiolas, and may be used to border beds of these flowers with excellent effect. They are very desirable for cut flowers, opening freely in water, and are exceedingly graceful and dainty. They do not possess the range of color of the gladiolas, being found only in scarlet and orange shades, but they have a place of their own in the summer flower garden, which could not well be supplied by any other plant. They are stored during winter the same as gladiolas, lifting the tubers when the foliage turns brown, and drying for a few days in a warm, sunny place; then removing most of the stalk and storing the bulbs in paper sacks and hanging them from the ceiling of a frostproof cellar or garret.

Tuberoses are more sensitive to cold and dampness than most other summer blooming bulbs, and must be started in heat and not planted out until all danger of frost is past. In preparing the bulbs for potting in spring, the thick growth below the bulb should all be removed, and all off-shoots. Plant the bulbs singly in four-inch pots, setting them with the tip just above the surface of the soil, or plant them in rows in the hot-bed, and this is preferable, as an even temperature is assured with less trouble than in the house. Plant out when the soil and nights are warm. The double pearl tuberose will grow so tall a flower spike that staking will be necessary, and for this the 
bamboo stakes are admirable, as they are less conspicuous than wooden stakes and, as they do not decay, can be used from year to year.

Tuberoses are excellent combined with gladiolas as the blossoms are not conspicuous enough for mass planting, but are fine for cutting and for the delightful, if somewhat heavy, odor. Tuberoses are sometimes late in blooming, but such plants as have not perfected their blooms at the approach of frost may be lifted and potted for the house or conservatory, as they are not in the least disturbed by the process.

As the bulbs will not bloom the second year it is not necessary to lift those which have finished blooming unless one cares to grow the little offshoots for a couple of years until they, too, reach blooming size, but as the blooming size bulbs can be purchased so cheaply this hardly pays for the time expended in their care.

Summer oxalis is a useful little summer-flowering bulb, excellent for carpet bedding, for filling up gaps in the border caused by the failure of seeds to germinate or plants to grow.

The bulbs of this variety of oxalis are so tiny that they are usually bought by measure rather than by the dozen or hundred. They need only to be pressed into mellow soil where they are to bloom. The bulbs in spite of their small size have a remarkable vitality and energy, and long before it will seem possible for 


\section{MAKING OF A FLOWER GARDEN}

growth to start, the first tiny leaflets will be seen breaking the soil and bloom will follow so quickly as to seem simultaneous. A warm, sunny situation should be chosen, as the flowers are apt to remain closed in the shade and on cloudy days. Set the bulbs two to three inches apart as allowance must be made for the development for the remarkable production of new bulbs. When the time comes for lifting the bulbs in the fall, not the one little bulb planted in spring will be in evidence, but it will be found that a remarkable growth has been going on under the ground during the summer, of which the delicate flower and foliage above ground has given no hint. In place of the one little bulb planted in spring a long, fibrous core, not unlike the soft cob of an ear of corn has formed, and, like the corn, it is completely surrounded with tiny bulblets, the whole forming a growth from three to five inches in length and an inch and a half to two inches in diameter. Each of these little bulbs will be removed for separate planting in the following spring. A tea cup full of bulbs planted in spring will, not infrequently, give a peck of bulbs by fall, and these can be sorted and only the largest retained for future planting. No other bulbous plant known equals this in productiveness. The care in winter is simply to lift the bulbs, dry in a warm, sunny position for a few days and store in paper sacks with some light chaff-such as buckwheat chaff-among them, in a 
dry, frost-proof place until time to replant in spring.

Tigridias are showy, attractive bulbous plants of the summer garden, requiring the same treatment as montbretias and gladiolas, except that they are the better for starting in wármth, and should be stored in a dry place during winter, as they are somewhat addicted to mold. They are excellent for combining with gladiolas, as they are not sufficiently heavy in foliage and flower to be at their best alone. The large, showy flowers remain open but one day, but each flower is succeeded by another so that blooms have the effect of being far more lasting than they really are. White with violet markings, golden yellow, golden yellow spotted with crimson, ivory white with yellow center spotted with crimson, and rosepink with yellow, variegated center are the principal colors, and all are unique and beautiful and well worth a place in the flower garden. They are useful to combine with hardy lilies, as they furnish bloom at a season when these are no longer in evidence; indeed, the chief function of many of our summerblooming bulbs is to extend the season of bloom of beds devoted to spring or June flowering bulbs and perennials. Requiring little room for growth, they may be interspersed between the roots of the more permanent plants and will benefit from the protection these afford from the summer sun and drought.

Crinums are among the bulbs which should be 
considered as summer bedders, for it is the only system of growth which succeeds with this rather difficult plant. Under expert culture it is a fine greenhouse and conservatory plant, but is something of a failure in amateur hands. If, however, a few simple rudiments of culture are mastered it becomes one of the most satisfactory bulbous plants grown.

The crinum makes a very large and solid bulb with a long neck, and an abundance of thick, fleshy roots. When it is received from the florist most of these roots are, necessarily, removed. It has had a season of rest and should be in condition at onee to begin growth and the formation of buds. It should, therefore, be planted out in the open ground as soon as the soil and the nights are warm. It must be planted in the sunniest, hottest spot available-a position beside a south wall which will draw and retain all the heat of the sun is ideal. Very rich soil-one underlaid with a foot of old, decayed manure and topped with a compost of fibrous loam, sharp sand, leaf mold and well rotted, fine manure is best. In this the bulbs should be set with the entire neck and a showing of the top of the bulb above ground. Water very freely until the bulbs have made a complete leaf development, and then withhold water entirely, allowing the plants to dry out and bake, and bake, and bake. The hotter and dryer the better. Then with the appearance of the first hard rain, great, fleshy 


\section{BULBS FOR SUMMER BLOOMING}

buds will appear, in a night, as it were, and will soon hold aloft the great rosy-white flowers, indescribably sweet and stately.

After the blooming period is over a second and even a third florescence will often follow if similar conditions of growth and complete rest are induced.

The bulbs may be left in the ground as long as frost can be kept from them and coldframe or spenthotbed treatment conduces admirably to this, but at the coming of cold weather they must be lifted and stored in boxes of dry soil in a warm cellar-a furnace cellar being a favorable place for them-until time to plant out again the following June. 


\section{CHAPTER VIII}

PL,ANTTS FOR VARIOUS SITUATIONS

Ornamental leaved plants are by no means confined to the cannas, caladiums and coleus so much in evidence in our summer lawns and gardens. There are many hardy perennials of most effective foliage that, once planted, increase in decorative value from year to year, and make an appreciable difference in the care and expense of the grounds.

For effective permanent planting there is nothing more desirable on the lawn than a large round bed of ornamental grasses. These, once established, require little care beyond an annual removing of the dead canes in spring, quickly accomplished by fire, which does less damage to the plant than to eut them back, leaving the stubs of the old canes to delay the growth of the new foliage. A mellow soil composed of wood or marsh earth, and good loam enriched with old manure, if applied in spring, or a heavy mulch of manure in the fall, which may be spaded in in spring, is about all they require, but water should be given 
frequently during mid-summer for the development of the tallest canes and generous plumes.

The tallest of all the ornamental grasses is found in the Arundo Donax, which when well established, makes a growth in good soil of twenty feet, and can be used with good effect for the center of beds of lower growth, as it is not as full in its development as some of the smaller sorts.

Erianthus ravennæ is an exceptionally fine grass which may be grown next to the Arundo Donax, making a growth of twelve to fifteen feet when established and showing finer plumes than the Arundo.

The Eulalias, Japonica and variegata, are beautiful both in foliage and manner of growth, being more erect and compact than the Erianthus, which has more of the fountain-like form of the Gyneriums. The variegated form is especially beautiful. Gracilima univitata is a lower-growing form of Eulalia and can be used as a border plant for the taller sorts. Like the Erianthus, it shows a silver midrib and a silvery panicle of bloom. To these may be added the hardy fountain grass-Pennisetum Japonicum, also a drooping sort, but showing a purplish bronze in the flower head.

All but the Arundo Donax can be raised from seed sown in spring in a coldframe and wintered under glass and set out in permanent beds the following spring. They are all long-lived plants, especially the 


\section{MAKING OF A FLOWER GARDEN}

Erianthus, often enduring twelve or fifteen successive years of growth in one position. Often it will be found that volunteer plants have come up in favorable spots about the grounds, and these may be lifted and transplanted into other beds or in hedges, for which there is nothing finer.

Not the least charm of the hardy grasses is the food they afford for the winter birds, who come in flocks on snowy mornings to feed on the seeds of the feathery plumes, and it is indeed a pretty sight to see them bend beneath the weight of snowbird, sparrow and junco.

For a background, or for a tall growth in the center of beds or plantings of lower form the Aralia Cashmeriana is a very ornamental plant with attractive foliage and panicles of small white flowers in early summer. It grows five to eight feet in height and is of easy culture. The bocconia is a stately plant of distinctive, glaucus green foliage and stem, the under side of the leaves being snowy white, and during July and August it is crowned with feathery panicles of creamy-white flowers. It makes a noble clump which always attracts attention and requires little care beyond good soil and to have the rhizome shoots destroyed to prevent its spreading beyond bonds. It is a long-lived plant, dying to the ground in winter and springing up with renewed vigor year after year, often remaining twenty years in possession of the same 
bit of ground. It is easily. raised from seed, which may be sown in the hotbed in spring and will make an effective plant the first season.

The Gunnera scabra, or Chilian rhubarb, is a magnificent ornamental plant when well grown-wellestablished plants forming a clump five feet in height and fifteen to twenty feet in diameter. To produce this superb growth, however, it must receive liberal treatment; rich soil, abundant water supply and a sunny but sheltered position and winter protection.

The large varieties of garden rhubarb make handsome plants under favorable conditions. One growing in a corner of my own garden in rich soil and a protected position throws up annually flower heads far above my own head and produces enormous tropical looking leaves of nearly three feet in diameter.

The Rodgersia podophylla is another stately plant requiring about the same conditions as the Gunnera. Grown in rich soil in a sunny situation and given abundant water it produces its five-lobed leaves from two and a half to three feet in diameter, which change from bright green to a metallic-brown hue. In addition to its ornamental value as a foliage plant it is crowned in mid-summer with fluffy sprays of spirealike white flowers. Another form of the Rodgersia - the tabularis-has an attractive, pale green foliage eighteen inches in diameter on three to four foot stems. During mid-summer it bears six-foot stems 
of fluffy white flowers. These two forms should be purchased in plant form of the florists.

The yuceas are too well known as isolated specimens to need description, but one would hardly recognize this old garden favorite when found growing in large, well-cared-for beds, as it appears in the large city parks. Yucca filimentosa is the variety employed in the parks, and this throws up tall flower seapes five or six feet high and is only excelled by Yucea filamentosa variegata, which is distinctly margined with creamy white. Both these plants should be planted in masses for fine effect, and once planted will be a permanent and beautiful feature of the grounds. Polygonum cuspidatum is a desirable hardy ornamental plant for a background for lower growth, for filling in waste corners and for many places where a free-growing, attractive plant is needed. The foliage is handsome and enduring, and the plant is entirely free from insect pests of all sorts. In mid-summer it is covered with masses of foamy, greenish-white flowers, which spring from the axis of every leaf. It makes a rhizome root, so that its greatest fault is a tendency to spread, but it is easily eradicated, and if the new growths are kept down the parent plant will make a much more erect, effective growth. It is, at maturity, six feet high. The smaller plants are useful in porch boxes and 
for a screen for sleeping porches. They will thrive in any situation and condition.

There are many low-growing foliage plants among the hardy perennials that are useful for edgings for beds of ornamental plants, and will thrive with little care, increasing in beauty from year to year.

Among sun-loving plants for warm, sunny positions the annual sunflowers are a most interesting class of plants. The miniature varieties are especially desirable, many of them possessing curiously twisted petals like the cactus dahlias, which make the flowers exceedingly graceful and picturesque. The icolors range from a nearly white type to a clear lemon, and through varying shades to deep, golden yellow. Stella has flowers of the richest golden yellow, while Orion, an improved variety of Stella, has petals twisted like a cactus dahlia. Both of these varieties bear single flowers, but there are many double forms well worthy of culture. Chrysanthemum-flowered is perfectly double and resembles in the fluffy doubleness of its flowers a chrysanthemum or aster. Double White Miniature has flowers nearly white.

It is doubtful if a more popular flower has been introduced in the last score of years than the golden glow; this so closely resembles the sunflowers as to be considered by many as one of that family; it belongs, however, to the genus Rudbeckia or cone flower. Most members of this family are distinguished by a 
prominent, cone-shaped center from which they derive their name; this, in the case of the golden glow and other double varieties is not noticeable on account of the double character of the flower, but in the purple cone flower it is very conspicuous, the rosy-purple petals encircling a rich, brown cone dotted with golden spots arranged in spiral lines. The flowers are very large and conspicuous, often six or seven inches in diameter and always attract attention. Newmani is a fine flower with bright orange petals surrounding a black cone, a striking and conspicuous flower. Fulgida, a double form, closely resembles the well-known golden glow. Unlike this plant, the sunflowers do not increase by throwing out young plants around the crown of the old plant in such profusion as to make its presence in the garden somewhat of an embarrassment at times. It is best, in case of the golden glow, to lift and reset it every year or two, saving a few of the finest plants and discarding the rest and giving those retained abundant room that they may make stocky, strong-stemmed plants less prone to come down under a heavy rain.

All of this class of plants are of the easiest culture, requiring only a warm, sunny position and good, fertile soil. An occasional cultivation with the hoe or a mulching with lawn clippings during the hottest weather will do away with the necessity of watering, 
so insistent in the case of many plants, and reduce the care of this class of plants to a minimum.

There are several varieties of plants that much resemble in color and form, if not in texture, the sunflowers; the sanvitalias, for instance, which bear showy, double, bright yellow flowers all summer. These may be used to edge beds of dwarf sunflowers. The yellow zinnias and the yellow marigold may also be used in this connection. All thrive under practically the same conditions. The Gaillardias resemble somewhat the Rudbeekias, having a distinct center, but show colors not found in the sunflowers, and are handsomely zoned with two or more colors. Both the annual and perennial varieties are easily raised from seed, blooming the first season if started early in the house or hotbed and continuing until frost. Once established they will practically take care of themselves.

Coreopsis are admirable, slender-stemmed, graceful flowers excellent for mixing with the more angular and stiff sunflower and cone flowers. Like the Gaillardias they are easily raised from seed sown in the open ground in May or in boxes in the house in March and transplanted to the open ground when the trees are coming into leaf. They require little care, and where time is at a premium the bed may be put in good condition, heavily mulched with lawn clippings and then left to take care of itself. The coreopsis is 
excellent for cutting, having long stems and remaining in perfection for a long time in water. Indeed, all of the flowers listed are remarkable in this respect.

Strongly resembling the coreopsis, the calliopsis produces its golden yellow flowers throughout the summer, rejoicing in the hottest sun and asking little attention save the room to grow and be beautiful. It is easily grown from seed which should be scattered where the plants are to bloom and thinned to stand eight or ten inches apart.

Aside from the sunflowers, and flowers which in more or less degree resemble them, there are many plants which rejoice in a warm, sunny situation and may be planted in places where few plants would be available. The Eschscholtzias, or California poppies, make lovely sheets of bloom and are most effective when planted in large masses or used to border, or to intersperse, between taller-growing blue flowers, such as blue larkspur, blue iris, blue lupins, monkshood, and the like. Though the prevailing color is the clearest, most golden yellow, there are several hybrids which are a distinct departure from the type. Mandarin, for instance, has the inner side of the petals of a rich orange, while the outer shows a brilliant scarlet. Rose cardinal shows the inner petals white and the outer rose colored. Dainty Queen is a pale coral-pink, both inside and out, and Carmine 
King is, as its name indicates, carmine. Alba is a pure white form, but it is in the yellow varieties that the flower is best known, and it is this color that is recognized as the State Flower of California.

All of us know, and many of us love that sturdy little salamander, the portulaca, which so delights in a hot, dry situation. The double flowers are exceptionally attractive, and the plants are fine for edging, carpeting under taller-growing plants or for use on the rockery. It is only necessary to scatter the seed sparsely over the surface of the soil and wait for results. Once established in the garden the portulaca may be depended upon to come up season after season of its own accord. All single flowers should be pulled up as soon as they show bloom and not allowed to go to seed, as they bear an enormous amount of seed and one pod is sufficient to seed an entire bed. Scarlet, crimson, white and yellow are the colors produced, and all are attractive, but the white are the daintiest of all, and look far too delicate for such an exposed position as the portulaca delights in.

Most poppies are sun-loving plants and light up a garden with a very blaze of color during their season of bloom. This is especially true of the Matilija poppy of California, whose great white blossoms are borne aloft on tall stems five or six feet high, which often bear a dozen or more expanded flowers at one time. Almost as distinctive and beautiful is the 
annual poppy, the Bride, whose great white cups are often the size of a pint bowl and borne aloft on stems five feet or more. I have grown them, solitary specimens, in sunny positions, of a size that made it necessary to bend the flowers down to see the golden anthers which made beautiful the interior of the great white cup.

The Hunnemannias, or bush Eschscholtzias make stocky plants covered with large buttercup-yellow, poppy-like blossoms which 'cover the plants throughout the summer and fall. The foliage resembles the ordinary Eschscholtzias somewhat, having the same glaucus color and feathery form.

The golden bartonia is another showy annual well adapted to sunny positions. The foliage is grey, downy and thistle-like, the flowers, golden-yellow and exceedingly showy and brilliant in the sunshine. The seed should be sown where the plants are to bloom, as they do not bear transplanting well.

One of the most satisfactory annuals for the garden is found in the Arctotis grandis, with its white, daisylike flowers encircling a golden center and showing blue reflexes on the outer side of the petals. It makes many-branched plants and is covered from early summer until hard frost with its beautiful flowers. No flower with which I am acquainted is more valuable for cutting, the flowers lasting in water an incredible time and the buds opening quite as well as though 
growing on the plant. They should be placed in a sunny position in the house, however, otherwise the flowers will remain closed, as they do at night and on cloudy days in the open. The plants are easily raised from seed, which may be started early in the house or hotbed and planted out in May, or the seed may be planted in the open ground in May, but earlier flowers are obtained by the first method. The Arctotis is much given to coming up self-sown, so that once established in the garden one is likely to have a permanent supply of it, though it never comes up freely enough to be troublesome.

If one is so fortunate as to have a secluded, unoccupied spot in garden or lawn, near to a summer house or garden seat, he may plant here those flowers of the dusk which, shunning the glare and publicity of the day, fold close their petals until the shades of night draw a protecting screen about them when, lo, there spring open to the night blossoms of white and of gold, of crimson and pink, filling the air with their perfume.

All fragrant flowers are more searehing and subtle in their fragrance when wet with the dew, but a few only unfold their sweetness to the night. Among the few night bloomers probably the best known is the old garden favorite, the four a'clock, which opens its flowers about that time in the day, continuing in bloom until the following morning. These are quite robust 


\section{MAKING OF A FLOWER GARDEN}

plants and bear multitudes of showy flowers which at evening emit a strong, agreeable fragrance. Equally as well known is the old form of the evening primrose; few of us but can remember the many hours spent, in childhood, in a vain attempt to watch the sudden unfolding of their yellow cups. A moment's inattention and, lo, the closely folded bud of an instant before is a wide awake flower smiling at our discomfiture. What is the secret of their unfolding that they so jealously guard it?

One of the most attractive of our night bloomers is the Nicotiana affinis, though this flower remains open on cloudy days and in shady positions. It is one of the most satisfactory garden plants, and combines so successfully with searlet flowers that it should be liberally planted in shady corners where salvias or other scarlet flowers will grow. Usually it self sows and comes up here and there about the garden. I have not sown seed of any of the nicotianas for several years, but I never fail of plants of both the Nicotiana affinis and Nicotiana sylvestris. Nicotiana sanderioe is a newer form of nicotiana, which comes in shades of red and is a very free bloomer. It is a rather later plant to come into bloom, though if one took pains to sow it in the hotbed in spring or in coldframe in fall it would give earlier results. I never sow it at all, depending on volunteer plants, and I find it exceedingly useful, as it oomes into bloom at a time when other 
flowers are scarce, and looks well with the anemones, which bear it company in the fall garden. It usually comes up along the edges of the path, and I transplant it where I wish it to bloom, but last spring I treated all garden paths with herbicide, so shall miss my usual fall offering of nicotianas.

The evening flowering stock, matthiola, is of little value except for its fragrance, but should be planted in conjunction with other evening bloomers.

Plant the moonflower to cover the seat or arbor; this will give an abundance of lovely white flowers at night and on cloudy days. Plant either the hardy or the annual form. If the latter, soak the seed in warm water for some hours before planting.

These little bits of special gardening add much to the interest of plant culture and will frequently make available an otherwise waste bit of land.

Another good use to which an unoccupied corner may be put is to devote it to the starting of plants of hardy perennials, shrubs or trees from seed. A quite small piece of ground planted to seeds of hardy perennials in August or early September will furnish enough plants for an entire hardy garden, and the plants thus started will be ready for transplanting into permanent quarters at the time the seed would be going into the ground in spring, and will bloom the same year. Thus one saves a year in time. Many kinds of ornamental shrubs and trees may be grown 


\section{MAKING OF A FLOWER GARDEN}

from seed, and one will be so busy with other matters that they will arrive at an effective size before one realizes that it is to be expected of them. I often put off the planting of things of this sort thinking it will be so long before they come into size or bloom, not realizing that if I had planted them when I first thought of it they would have already reached maturity.

\section{PLANTS FOR VARIOUS SITUATIONS} SUN-LOVING PLANTS

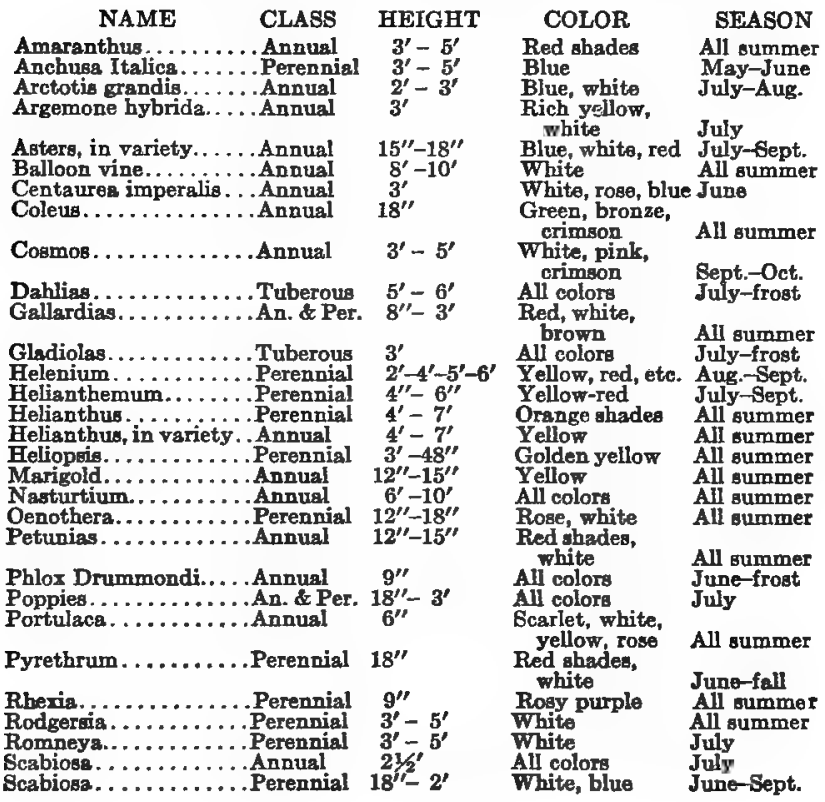




\section{PLANTS FOR VARIOUS SITUATIONS \\ SUN-LOVING PLANTS (Continued)}

NAME CLASS HEIGHT COLOR

Btokesia.............Perennial 18 ${ }^{\prime \prime}$

Sweet Peas, in variety. . Annual $3^{\prime}-6^{\prime}$

Tagetes............. Annual $13^{\prime}-6^{\prime}$

Blue, white

All colors

Yellow
SEASON

June-Sept.

All summer

All eummer

\section{SHADE-LOVING PLAN'TS}

\section{NAME}

\section{CLASS}

Anemonopsis..........Perennial

Chamelirium...........Perennial

Claytonia ............. Perennial

Convallaria............Perennial

Digitalis. . . . . . . . . Perennisl

Ferns. . . . . . . . . . . . . Perennial

Marahallia................ Perennial

Podophylium . ...........Perennial

Polemonium...........Perennial

Polygonatum ........... Perennial

Primulas............. Perennial

Prunells

Perennial

Bbortia................ Perennial

Spirze Aruncus......... Perennial

Spiræa Filipendula.....Perennial

Spiræa gigantea. . . . . . Perennial Spirma tlmaria. . . . . . . Perennial

Spirea palmata........Perennial

Btenanthium...........Perennial

Tricirtis................ Perennial

Trillium. ............Perennial

Vinca................Perennial
HEIGHT

COLOR

SEASON

$2^{\prime}$

$6^{\prime \prime}$

$B^{\prime \prime}$

$3^{\prime}-4^{\prime}$

$1^{\prime}-3^{\prime}$

$15^{\prime \prime}$

$3^{\prime}$

$12^{\prime \prime}$

$3^{\prime}$

$6^{\prime \prime}-9^{\prime \prime}$
Dwarf
$6^{\prime \prime}$
$15^{\prime \prime}$
$5^{\prime}-6^{\prime}$
$3^{\prime}-4^{\prime}$
3
$4^{\prime}-5^{\prime}$
$18^{\prime \prime}$

$12^{\prime \prime}-15^{\prime \prime}$
Violet

Creamy-yellow

Pinkish-white

White

White, rose, mauve

All summer

ariegated All summer

White

Pink

Blue, white

White

White, yollow, red

Purple

White

White

White, touched with pink

White

White

Crimson

White

White, spotted brown

White, crimson

Blue
Late summer

June

May

May

Ang.

May

May-June

May

All summer

Early spting

Juno-July

June-July

June-July

June-July

June-July

Aug.

Fall

May

June
May-June

\section{TALL-GROWING PLANTS FOR BACKGROUNDS AND} SCREENS

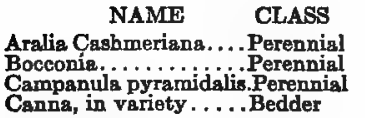

Cephalaria..........Perennial

Cosmos...............Annual

Delphiniums.........Perennial

Grasses, ornamental. . .Perennial

Helianthus............Perennial

Hibisous...............Perennial
HEIGHT

$5>-8^{\prime}$

$6^{\prime}-8^{\prime}$

$4^{\prime}-6^{\prime}$

$3^{\prime}-6^{\prime}$

$6^{\prime}$

$3^{\prime}-5^{\prime}$

$4^{\prime}-6^{\prime}$

$4^{\prime}-12^{\prime}$

$3^{\prime}-6^{\prime}$

$4^{\prime}-5^{\prime}$

\section{COLOR}

White

White

Blue

White, reds, yellow

Yellow

Pink, whito, crimson

Blue, white, purple

Green

Yellow

White, pink
SEASON

June

Aug.

Aug.

All summer

June

Sept.

June-fall

All summer

June-frost

Aug.-Sept. 


\section{MAKING OF A FLOWER GARDEN}

TALLGROWING PLANTS FOR BACKGROUNDS AND gCREENS (Continued)

Hollyhock.......... Perenvial $\mathbf{6}^{\prime}-\mathbf{7}^{\prime}$

Nicotiana sylvestris.....Perenninl

Physostegia............ Perennial

Polygonum .............. Perennial

Ricinus Borboniensis... Annual

Ricinus zanzibariengis. . Annual

Spirea, in variety..... Perennial

gtenanthium............Perennial

Yucce...............Perennial

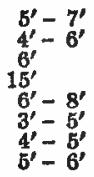

COLOR

SEABON

White, pink, yel-

low, orimson, white

Aug.

White July-frost

White, pink July-Aug.

Greenish white Aug.-Sept.

Green

All summer

Bronze, green All oummer

White, red, pink May-June

White

Aug.

Creamy white Juno-July

\section{LOW-GROWING PLANTS FOR EDGING, BEDDING AND THE LIKE}

NAME

\section{CLASB}

Acena.............Perennial Ajuga....................Perennial

Alchemilla...........Perennial Alyssum.............Annual

Alysaum saratile.......Perennial Arabis alpina..........Perennial Armeria..............Perennial Aubrotia.............Perennial Bellis (English daisy)... Perennial

Campanula Carpatica. . Perennial Cerastium............Peronnial

Draba..............Perennial Glechomo..............Perennial Hieracium........... Perennial Iberis................ Perennial Lobelia, Crystal Palace. Annual Lobelia heterophilla.... Annual Lychnis Visenria. . . . . . Perennial Mornine glory, dwarf... Annual Phlox Drummondi..... Annual Portulaca............Annual HEIGHT COLOR

Cuahion-like Crimson spines Carpet

Rock Trailing

1

Carpet

g" $6^{\prime \prime}-8^{\prime \prime}$

$6^{\prime \prime}-9^{\prime \prime}$

$$
6^{\prime \prime}
$$

Dwarf rock Creeping Low-growing Orange, red

$\begin{array}{ll}8^{\prime \prime}-10^{\prime \prime} & \text { White } \\ 6^{\prime \prime} & \text { Deep blue } \\ 6^{\prime \prime} & \text { Sky-blue } \\ 1 & \text { Deep red }\end{array}$
Purplish blue Inoonspicuous White

Yellow

White

Pink

SEASON

All summer May

All eummer All summer June-July April-May All summer Crimson, purple May-June Pink, white, crimson

White, blue White, silvery foliage

White Deep red June $11^{\prime \prime}$ $15^{\prime \prime}$
$6^{\prime \prime}$

Primula............Perennial

$$
6^{\prime \prime}-9^{\prime \prime}
$$

Prunella Perennial Low Bantolina.............. Perennial IDwarf

Sanvitalia............Annual ' Dwarf Gedum.............. Perennisl $6^{\prime \prime}-8^{\prime \prime}$

Saxifraga (Mogasea)...Perennial 12"

Saxifragas armentosa. .Perennial Trailing Tunica..............Perennial Low tufted Rose, scarlet, white, yellow

Yellow, orange, crimson

Purple

Evergreen with Bilvery-white foliage

Bright yellow White, yellow, crimson, pink June-Sept. Pink, rose, crimson Silvery foliage Pink White, yellow. blue.
All colors
All summer All summer

June All summer Mid-rummor Epring June-Nov. June-frost

All aummer

All summer

Spring All summer

All summer All summer April-May All summer All summer

All summer Aprí-May 
The foregoing list of plants, while fairly comprehensive, is by no means exhaustive but is rather intended to direct the reader's search for special plants for special positions. Almost any good floral catalogue-Dreer's specially-will give detailed descriptions of the several plants and their various varieties from which intelligent selections may be made.

The heights given the various plants, as well as their season of bloom must be taken as approximate rather than definite, as the part of the country in which they are grown will have much to do with the size they attain. The nearer their native habitat they are planted the more generous, of course, will be their development. Then, too, the matter of a poor or generous soil, the amount of cultivation and general care will all be determining factors in the size they attain, their period of bloom, and size of bloom.

In the matter of vines the water supply is important, and the supplying of an adequate support will determine in a large measure the height to which they will grow. Certain vines, as for instance, the trumpet vine, if given a low support will grow to the top of it and then form a bushy head, ceasing, for all practical purposes, to be a vine. Such a trumpet vine growing on my own premises by the side of a gate post assumed this voluntary form, while a sister plant in the more favorable position supplied by a tall pear 


\section{MAKING OF A FLOWER GARDEN}

tree flaunts its blossom from the topmost branches. Another trumpet vine of which I knew, found entrance beneath the siding of a house and grew upwards, through the dark to the eaves of the second story, where it emerged and formed a bushy top, continuing to grow and bloom for years. For these reasons it is difficult to give a definite height for vines. Low-growing plants-rock plants, ground plants which creep or trail and have no upright measureare seldom specified in feet and inches. 


\section{CHAPTER IX}

\section{THE AMATEUR'S ROSE GARDEN}

ThE growing of roses is a thing apart in the garden calendar; no other flower exacts so large a toll of patience, care and labor as the rose; no other flower repays so royally in bloom and fragrance. It should be of the garden a thing apart, rare, cherished and a source of much sweet exultation and pride, every bloom a cause for rejoicing. It should have a place to itself, for the rose is an aristocrat among flowers and impatient of the presence of other forms of flower life. If there cannot be a space set apart for a real rose garden, then at least a bed to themselves should be accorded or, if roses for cutting are all that is desired, then a row through the vegetable garden will give excellent results, as the cultivation will be more certain and thorough. This is especially desirable in the growing of teas and hybrid teas. Out of nearly a hundred roses planted the past year a row of two dozen hybrid teas planted in a continuous row through the garden, with such low-growing things as beets and parsley planted on either hand did much 


\section{MAKING OF A FLOWER GARDEN}

the best, giving a constant succession of bloom all summer and was still covered with buds when severe freezing weather sent the plants into their winter covering to sleep until the bluebird's song should awaken them in spring.

A piece of land lying towards the east and south is best for the rose garden, as they are essentially flowers of warmth and sunshine. Some protection against rough winds on north and west is always beneficial, but should not be too close.

A rich, mellow loam, containing a portion of clay and well enriched with old, well-rotted stable manure, dug very deep and well drained, is essential for best results; where no clay is present in the soil it can be added and is well worth while. All the plants grown in pots for shipment in nurseries are grown in clay, and this is one reason they so well withstand shipping to distant points, as the clay adheres tenaciously to the roots, protecting them from injury. This it does when grown in beds, and less damage occurs from the ground freezing in winter or drying out in summer, as the roots are never entirely exposed to drought and cold. Clay also adds to the richness of the color.

The ground should be prepared, if possible, enough in advance of the receipt of the plants to have become settled, as newly worked ground is too porous for planting. A heavy rain after spading will put it in good condition. Should the weather be too cold or 


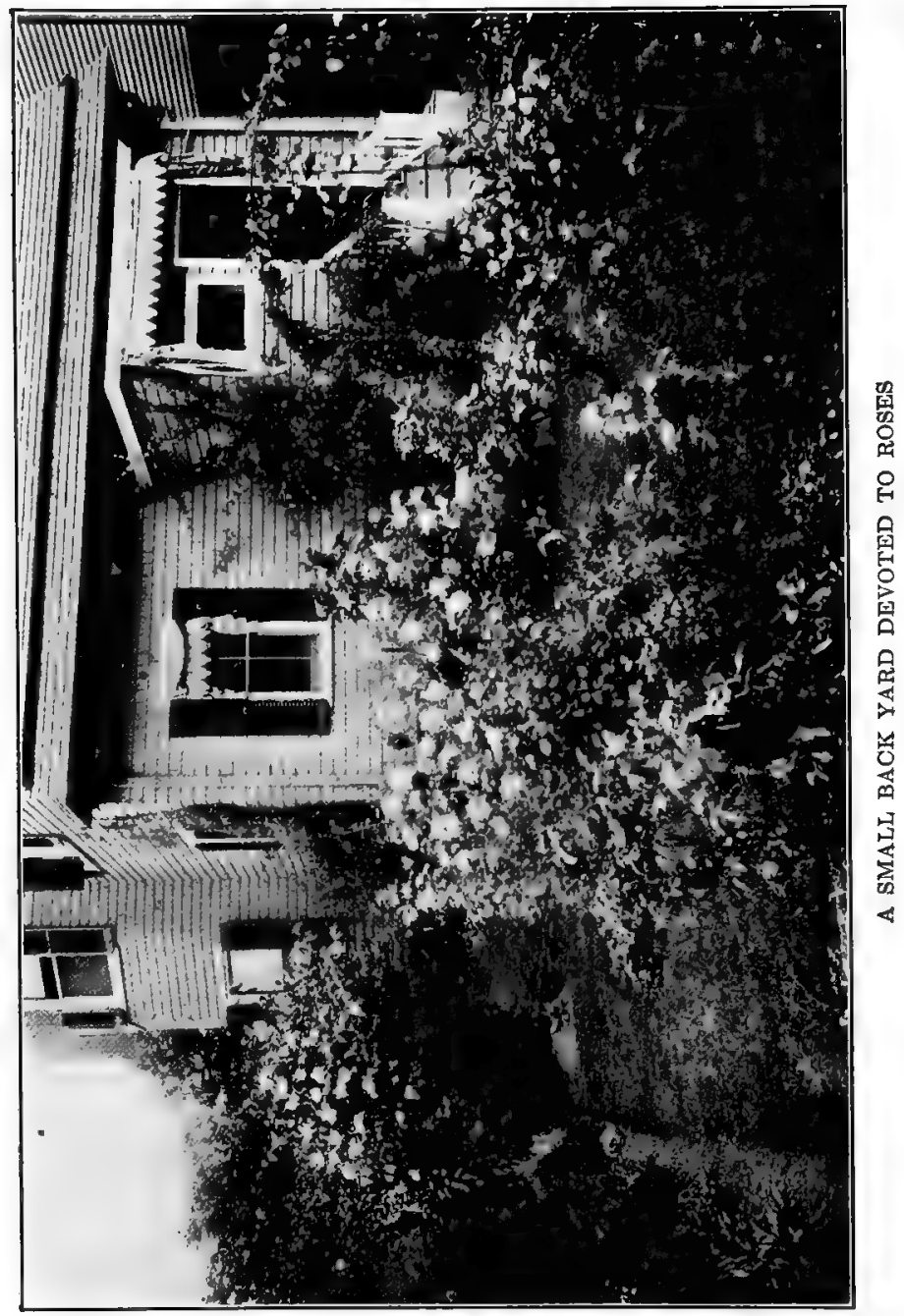




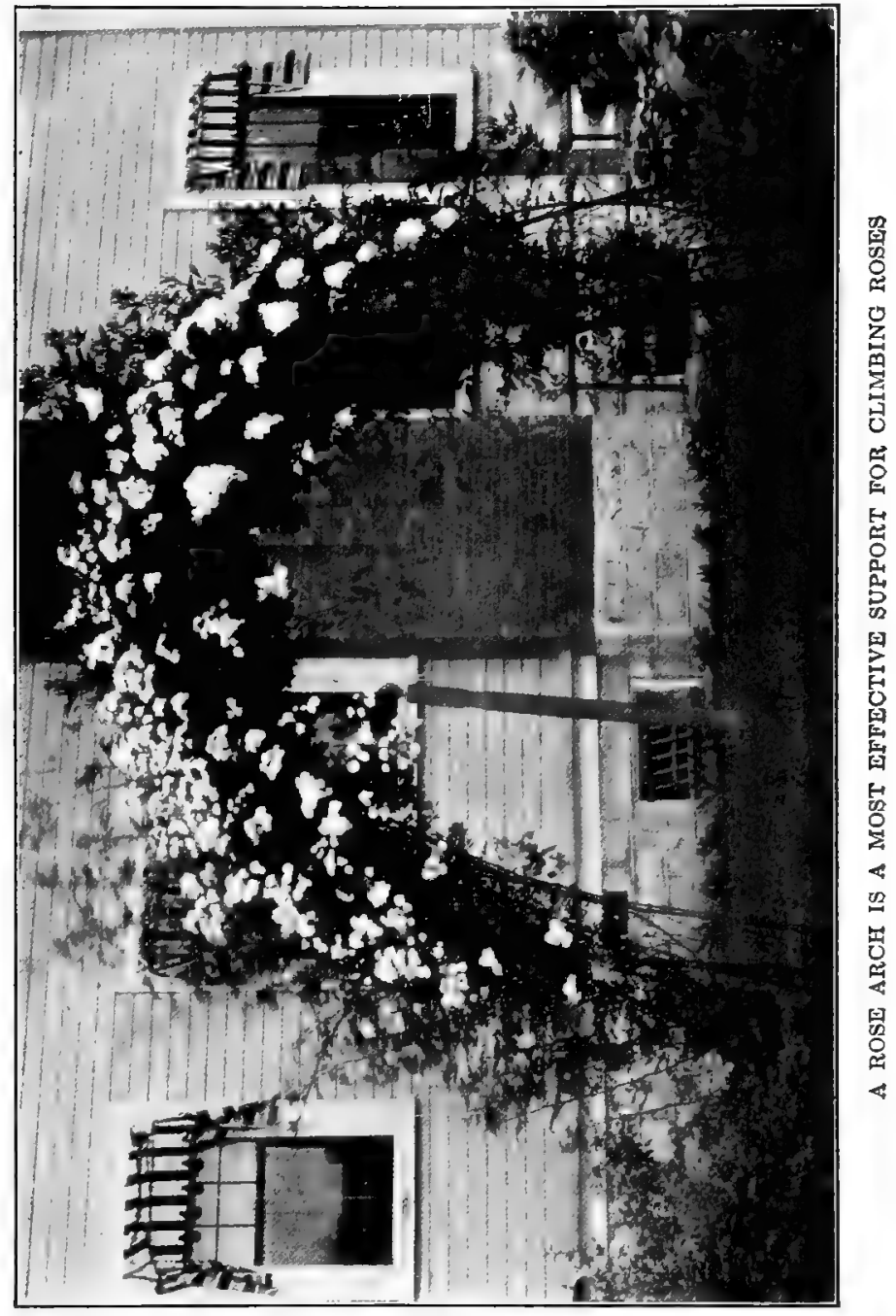


wet when the plants arrive they should be unpacked in a cool place, away from the wind, and if only a day or two is to elapse they need only be taken from the packages and stood upright on a table or in a box, setting the plants close together but with the tops uncovered. Generally roses reach one in excellent condition, the earth on the roots intact and the moss and paper quite damp; if in this condition nothing more will be required, but if somewhat dry the tops should be sprayed, allowing the water to run down inside the papers. If very dry it will be best to immerse the roots in lukewarm water until well soaked. Plants which come by mail with all earth removed should not be put at once in the open ground, but should be potted off in small pots not over three inches and allowed to rest and recover before planting. As a general thing roses will need no protection when planted out in early spring, but if there is much hot sun a screen on the west is beneficial and can be supplied by driving two or three stakes along the rows and tacking a strip of matting or burlap to them. This will protect from the sun without depriving the plants of air.

Any bruised or broken roots should be removed with a sharp knife, and any broken or straggly branches, but the majority of roses will need little pruning.

Only roses on their own roots should ever be pur- 


\section{MAKING OF A FLOWER GARDEN}

chased. Grafted roses invariably run to stock suckers and are a bad investment at any price.

Individual preference will, of course, be an important factor in the selection of varieties, but where an abundance of cut flowers is desired there is no question that the preference should go to the hybrid teas; these, once established, will give constant bloom from May until hard frost, and the blooms will grow finer and more and more beautiful as the plant increases in size and strength. If notable-sized flowers rather than quantity is desired then all but the terminal bud on each spray should be removed; this is an advantage, too, in cutting, as then there is no compunction over sacrificing buds, as there is when all the buds are allowed to remain. It would be difficult to name a short list of most desirable teas where all are so good, but it is safe for the amateur to start out with the several varieties of Cochet (pronounced "Cocha,") white, red, pink, crimson and yellow; the several Killarneys, Radiance, Charles Dingee, Madam Baden, Edward Mawley, and add to these as one's taste suggests. Of the hybrid perpetuals one should include Frau Karl Druschki, (the best white rose to date), Gen. Jacqueminot, Virginia Coxe, Paul Neyron, Prince Camile de Rohan, Fisher Holmes and Baroness Rothschilde. Virginia Coxe is listed as a hybrid tea but has the hardiness of the hybrid per- 
petuals, so I plant it with those roses ; it is, of all red roses, the sweetest and reddest.

In my opinion climbing roses run altogether too much to the rambler class. To be sure a well grown and well cared for rambler is very beautiful when in full bloom in June, but has little to recommend it the balance of the season, and might well be relegated to a less important place than a front porch and its room given to the large flowered, perpetual bloomers like climbing American Beauty, Mrs. Robert Pearyan exquisitely beautiful rose of tea type with wonderful buds of creamy white-Meteor and climbing Wooten, both exceptionally rich colored red roses of tea type, white Maman Cochet, Papa Gontier and others of the class. Where a rambler is wanted a better selection than crimson rambler is the ever blooming crimson rambler, Flower of Fairfield. Lady Gay, a cherry colored and white of most delicate beauty is one of the best of its class and a very free grower. The much advertised blue rose Veilchanblau is more curious than beautiful, being a violet rather than a blue, but is a very vigorous grower, making beautiful strong canes with handsome foliage.

Summer care consists of three important features -feeding, cultivating and fighting insect pests; the last should really come first, and last and all the time as there is little let-up, from the unfolding of the first leaf bud until frost, to the incursion of plant lice, 


\section{MAKING OF A FLOWER GARDEN}

thrips, slugs and mildew. Fortunately the rose bugs appear but once in a season, but the aphis we have always with us. With a good water supply many pests may be kept in check by spraying for from fifteen minutes to half an hour each day, but this will have no effect on blight, mildew and ills of that nature. A good insecticide-or several-should be at hand from early spring on. Before the first leaves appear spraying once a week with bordeaux mixture will control most of the ills the rose is heir to, especially black spot and blight. Lime sulphur solution is remedial for mildew and as a tonic, while hot water about one hundred and forty degrees will effectually remove all lice and slugs if used so that it reaches the under as well as the upper side of the foliage. Where the plants are slender enough to allow of dipping the tips of the branches into a dish of hot water very thorough work can be done with lice. The slugs work from the ground up so the water must be applied in the form of a spray. Picking all leaves that show perforations and destroying them is a great help; spraying with hellebore is also a standard remedy against slugs. Black spot is controlled by spraying, but every diseased leaf should be picked and burned. Always the new growth must be watched for lice as they appear first at the tip of the branches, where they may be easily controlled, but once spread to the 
under side of the leaves their eradication is more difficult.

Sufficient manure should be spaded into the beds, together vith rather coarse bone meal to supply the early growing needs of the plants, but at the appearance of buds additional food should be supplied; this may take the form of liquid manure prepared by filling a barrel with manure and water. A large lard barrel is a good size to use; this should be burned out to remove the grease and fitted with a wooden spigot an inch or two above the bottom on one side. The barrel should be set on a box or other support high enough to allow a watering can to be set under the spigot. Several inches of clean straw should be put in the bottom, then fill to the top with manure free from straw, cow manure being best. Then fill with water and cover to exclude flies. When needed draw off the liquid, replacing it with water so that the barrel is kept full all the time until the liquid becomes too weak to be of use. The barrel should stand in the shade in an inconspicuous but handy place. The liquid should be applied at regular intervals of once a week, but should not be given when the soil is dry-after a rain or watering with the hose is bestand its application should be followed the next morning with cultivation to restore the dust mulch.

Cultivation should be continuous throughout the growing season. Where the plants are in straight, 


\section{MAKING OF A FLOWER GARDEN}

long rows which admit of the use of the wheel cultivator it should be used, but where that is impracticable the hoe and scuffle hoe must be depended on. The scuffle hoe if held quite upright can be made to do quite deep cultivating and is invaluable for creating a dust mulch. The beds should not be allowed to dry out, but if faithful use is made of the cultivator or hoe it will not be necessary to water more than once a week, but that watering should be thorough, soaking down to the roots of the plants, then followed the next morning with a level cultivation.

A thorough cultivation to loosen up the soil in the afternoon, followed by a good watering and an application of liquid manure towards evening and a light scuffling of the soil in the morning to produce the dust mulch, will be a good order to follow and will keep the beds in flourishing condition for a week.

Cut all flowers as fast as they bloom, allowing none to wither on the plant and taking as long stems as possible; cutting down to a strong, outward turning bud will inerease the number of blooming shoots and the thriftiness and vigor of the plants. 


\section{CHAPTER $\mathbf{X}$}

\section{WINDOW AND PORCH BOXES}

The box may be as simple or as elaborate as one's means permit, but it must be borne in mind that the contents are the primal idea in its inception, the thing for which the box exists and, when once planted and sufficiently grown to be really effective, little if anything of the box will be seen. That it should be substantial and roomy enough for the purpose, inconspicuous enough to detract nothing from the contents and, if of wood, of a style and color to correspond with the house is really all that is required.

The metal boxes have much to recommend them, as they contain reservoirs for the storage of water and thus require less attention than one of wood, but simple boxes made from six or eight-inch lumber, well caulked with white lead before nailing together, supplied with a drainage hole near the bottom at one end, and fitted with a plug, will answer every purpose. Even the boxes in which scythes come can be utilized quite satisfactorily, but will require more water than a more substantially built box. A box 


\section{MAKING OF A FLOWER GARDEN}

eight inches deep and nine wide and as long as the window casing is a satisfactory size for single windows; oriole window and porch boxes will need to be somewhat larger.

The boxes should be placed so that the top is immediately below the window sill and securely supported, especially if under second story windows where the results of breaking loose would be very serious.

Plants placed in the restricted confines of a window box will require rich soil and a mixture composed of fibrous loam, or earth taken just below the crown of the grass from old sod, mixed with bone meal and old, well decayed manure is best. For north windows where ferns, begonias and the like will be grown the addition of leaf mold and sharp, white sand will be desirable, but on an exposed western side a heavier soil will be required. Fill the boxes quite full to begin with and in setting the plants press the earth very firmly about them, leaving the surface somewhat lower in the center than at the edges so that the water may remain more in the body of the box.

When the boxes are to be filled with plants from the greenhouse the roots should be disturbed as little as possible. Simply press pot and all into the soil so as to make a hole the size and shape of the pot; then invert the pot on the hand, tap it against the side of the box to loosen the ball of earth and slip it 
into the hole, pressing the soil about it. Planted in this way the boxes may go at once into the positions they are to hold.

When plants are received by mail for the purpose they should have one of two treatments-they should either be potted off into pots and set in the shade for a few days until they have established themselves suffciently to be turned out of the pot in a firm ball, or the boxes themselves should be put in a shady position, planted and allowed to start growth before being placed where they are required. Observance of this rule will avoid many disappointments in window box culture.

Boxes may be very inexpensively equipped by planting with cuttings from the house-plants, by placing them in some frost-proof, convenient place early in March and simply sticking cuttings of geraniums, fuchsias, vincas, and like plants where they are wanted; they will root quickly at this time of year and grow on very satisfactorily.

Very attractive and inexpensive window and porch boxes may be developed by the use of common garden plants raised from seed. The bright colors which make the boxes so charming are especially noticeable in many of the summer annuals. The Phlox Drummondi give an infinite variety of pinks, scarlets, dark reds and white and are indefatigable bloomers, harmonizing exquisitely with the pinks and dark reds. 


\section{MAKING OF A FLOWER GARDEN}

The ageratums are equally floriferous. Both the single and double petunias are exceptionally fine in boxes and choice should be made of the large or giant fringed sorts with their wonderful coloring and deep throats. Scarlet and white verbenas and white candytuft-this latter should have fresh sowings at intervals of two weeks-nasturtiums (these more especially for porch boxes); the dwarf scarlet zinnias, schizanthus, lobelias, dwarf morning glories, all may be utilized for window boxes at a cost of a few dimes.

As a general thing window boxes call for trailing rather than climbing vines, but there is usually much sameness in selection, trailing vinca, moneywort and the like being too often in evidence. Vinca, however, is very attractive if rather stiff, but is improved by nipping off the ends to induce it to branch, when it looks less lank. The variegated ivy geraniums are more attractive and have the added beauty of abundant and lovely bloom. Wandering Jew in the colored forms is especially good and for east and north windows the trailing fuchsias, abutilons and begonias are all beautiful and produce a most artistic box. There is one plant which I especially affect for north and east boxes-Panicum excurrens or palm grass. This is not listed by northern florists, but can be procured from any southern florist and is very striking with its long palm like leaves about three inches wide and as 
many feet long, arching gracefully over the sides of the box.

For vines which both climb and trail, festoon and drape themselves about the box in graceful profusion there is nothing more charmingly delicate than the maurandia, and the white flowered solanum and scarlet manetta vine are especially pretty when grown together. Where a tall climbing vine is desired there are three especially desirable vines to choose, the Cobaea scandens, the various Passilflora-P. Pfordtii, for preference-and the Japanese morning glory. Any one of these will climb to an upstairs window, blooming every step of the way, and are easy to control.

For south and west window boxes all the bright, sun-loving plants may be grown, geraniums, camphor geraniums, feverfew, petunias, verbenas, justitias, heliotropes, ageratums, Phlox Drummondi and coleus -if the tops are kept pinched back so that they do not get "leggy." Anything that would do well in similar exposures in the open ground may be used in the south or west box.

Those plants which love the morning sun, but shrink from the full glare of the sun at high noon and later, should find a home in the east boxes. Petunias, of course, which do well anywhere, ageratums, heliotropes, fuchsias, tuberous begonias, fancy leaved caladiums, Panicum excurrens, aralias, aspidistras bou- 


\section{MAKING OF A FLOWER GARDEN}

gainvilleas, cissus, discolor crotons, Impatiens $S u L$ tanas, and so on.

North window boxes are, aside from brilliant color, the most charming of all, for plants do so exceedingly well here if a proper selection is made. All the house ferns-Boston, Sword ferns, holly, Pteris tremula, aspleniums and the like; the asparagus ferns, especially Asparagus Sprengeri; the begonias, especially the ornamental leaved varieties other than the Rex; many of the smaller palms, the palm grass, abutilons, fuchsias, Wandering Jew, vincas, cissus discolor, will all thrive and show a freshness of green unknown to other exposures, and lack of brilliant bloom is compensated for by combining those plants with variegated foliage as the abutilons, the spotted farfugium, the variegated silver and purple Wandering Jew, and so on.

General summer eare consists principally in supplying abundant water, in keeping the vines in check, removing all dead leaves and nipping back too ambitious plants for, unless it is desired to screen the window underneath which the boxes are placed, they should not be allowed to obstruct the view; for this reason only those plants of moderate growth should be selected. For porch boxes, placed at a level with the floor and used in a measure as a source of privacy, taller plants may be selected and anything used which will thrive in a restricted area. I have used the 
Polygonum cuspidatum with excellent results in window and porch boxes where a mass of foliage was desired as a screen rather than a floral display. It is a very handsome plant with its ovate leaves of a rich green, red stems and, in August, wealth of foamy flowers of a greenish white. White, by the way, is about the most valuable color in all window planting and should be used freely, especially with shades of red and yellow and to lighten up an otherwise too sombre planting. The Polygonum, by the way, is good for sleeping porch boxes as it furnishes a sereen, and climbing rather than trailing vines may be selected. For balconies I always like bright flowers as, being rather high, the softer colors are rather inconspicuous. Trailing vines, too, are to be preferred and the nasturtiums are desirable. So common a vine as the wild cucumber can be used to advantage if it is removed as soon as it begins to fade. Its delicate flowers are lovely with pink geraniums, petunias, justitias and the like. 


\section{CHAPTER XI}

\section{VINES FOR EVERY PLACE}

A DIFFERENT vine for each position is quite possible, for nature has been generous indeed in her offering of material to soften and beautify the rugged face of a cliff or the gnarled trunk of a tree. Vines follow fleet-footed on the trail of death and decay to cover with blooming spray and fruited branch and create a new life more beautiful than that which has passed. The wild clematis and convolvula flaunt their blooms from tree and fence row; the wild cucumber makes delicate tracery of green and foamy white flowers along the debris of the neglected ravine; the woodbine flaunts from the crown of the dead monarch of the forest, and the wild grape-that sweetest of the vitis family when in bloom-haunts the woods and uplands where the wild elderberry grows.

All are cosmopolite in their requirements, flourishing quite as well in the suburban garden or the city back yard as in their native woodland habitat. All that is really essential for successful growth is some- 
thing for the vine to cling to and cover, for that is really the life of the vine; frustrate that intention and it withers and dies. Being, for the most part, things of the wild the more natural the conditions of growth and especially the fare provided, the more successful is their culture apt to prove. Growing in a wild state they are usually found well footed in deep leaf mold and mellow loam, with eonditions affording protection to the roots from sun and drought. Unfortunately many of the places for which vines are desired in our gardens and about our houses do not afford these conditions. A place against the side of a house, for instance, is about as discouraging for a vine or plant as can well be selected; a place in front of a broad porch, especially one with wooden floor and latticed foundation is far better, as the soil here is liable to be natural and not composed of the hard pan, broken stone, brick and lime that usually distinguishes that in close proximity to the house walls.

When, however, these unfortunate conditions prevail there is but one remedy - the digging of a wide and deep hole, removing the soil and replacing with a good compost from the compost heap, manure pile and garden. Especial attention must be given to this matter of soil, for a vine is a permanent planting, not to be changed as long as the vine survives, which may exceed in years that of the gardener who plants it. 


\section{MAKING OF A FLOWER GARDEN}

At any rate it is likely to be a matter of years during which the vine will demand more and more in the way of sustenance, which now can only be supplied in the way of top dressing.

Where the soil about the house is fairly good, even then planting close to the wall has disadvantages, as the plant is apt to suffer for lack of moisture, the tendency being for the water to run away from the house, and on the side which receives little rain the ground is naturally quite dry. For this reason it is better to plant the vine out a distance from the wall, even as much as three feet sometimes, according to conditions. This need not interfere with the care of the lawn or leave an unsightly bare spot, as it is only necessary to lay back the sod, set the vine in a deep hole of fine soil and bury the stem of the vine under the sod up to a point a few inches from the wall, where it may emerge and attach itself to the support provided.

Certain wines, like the trumpet vine, the woodbine, the climbing hydrangea, will send out roots along the buried stem and so perfect a much better root system than when planted in the usual way.

The matter of support is also of much importance and should, if possible, be provided from the start, as a failure to find support at once often results in the loss of a vine or much lost energy and growth in the search. Such vines as attach themselves to walls by 
aerial rootlets need no support other than to be brought close to the wall at the start, so that the young rootlets may lay hold while still full of sap. If they once dry out their usefulness is lost and a vine long enough to be blown about by the wind will seldom make a firm attachment to a wall.

Vines which require netting for support-as the various clematis-should have it in place when planted. Most of the clematis are quite hardy, but a few, those that bloom on the last season's wood, as Madam Edward Andrea, are better for being laid down during winter and for this reason the netting should not be nailed to the wall of the house, but to strips of wood, which in turn may be fastened to hooks in the wall so that the netting can be easily detached and rolled up on the ground and protected. Vines that do well on cords, as most of the annual vines, are easily cared for by taking two strips of wood, one for top and one for the bottom, and driving fence staples in them about a foot apart and running twine-butcher's twine is good-back and forth through the staples from top to bottom. When the time comes to remove the vines it is easily done by untying the ends of twine and pulling them out, leaving the vines in a bunch on the ground where they are easily removed. This is far easier than pulling the vines away from the twine.

A vigorous growing vine throws off a greater quan- 


\section{MAKING OF A FLOWER GARDEN}

tity of water through its leaves than any other kind of vegetable growth, and to meet this heavy evaporation must receive an abundant water supply, and not only is this necessary at the root, but frequent spraying of the foliage will add much to its beauty and health. The Japanese Ipomæa is a notable example of this need of moisture. Give it enough to moisten the soil and it will grow and bloom, but give it enough to soak the soil to a puddle, after a season of ordinary watering and the blossoms will almost double in size over night. It must not only have sufficient moisture to make the food in the soil available -for in dry soil the food is locked up-but enough for a good drink besides, a drink that will reach clear to the topmost tendrils.

The choice of a vine is not only a matter of beauty or of hardiness; it must be one of suitability also. If an object is to be screened against the sun or against curious observation, then a dense growing vine should be selected, such as the Aristolochia Sipho, the Ampelopsis Veitchi, Ampelopsis Lowii or tricolor-this last a delightful vine, both in its manner of growth, its beautiful grape-shaped foliage marbled with pink, white and grey on a green ground, its peacock-blue berries in late fall and its perfect hardiness. It does admirably on a north exposure and if a low wall is to be covered it may be cut down to within three feet of the ground every fall and will make a rank growth 
the following year. Indeed I think it is more beautifully marbled when so cut back, as the new growth is more in evidence, being lower.

The wild grape should be grown, if only for its entrancing fragrance when in bloom. All the Vitis family are admirable, but there is one less well known that is the most beautiful of all the family-Vitis Henryana-a variety with five lobed leaves resembling dark green velvet with a silver mid-rib; to my mind the most beautiful vine I have seen.

Schizophragma hydrangeoides is another remarkably fine vine, very rarely seen, but which should be far better known. Perhaps its rather high initial cost may have something to do with its rarity, small plants costing a dollar, but it would be cheap at a much higher price were one more familiar with its merits. Imagine a fine hydrangea climbing up the wall of the house-for it is a self-supporting vine, clinging firmly to stone, brick and even to wood-and covered in June with great heads of white blooms similar to Hydrangea paniculata, but unlike the latter in that the blooms do not turn pink as they fade, but retain their creamy white color. The foliage is ovate, dark green and waxy and the thick, woody stems red. It is a vine that always attracts attention, either in leaf, flower or naked branches, and is of the easiest culture, doing best on the north or east side of the 


\section{MAKING OF A FLOWER GARDEN}

house, in good woodsy soil, and requiring no protection in the severest winters.

Unless a very large space is to be covered most of the clematis should be cut back in fall or early spring. Clematis paniculata (Virgin's Bower) can be cut to the ground every year and be all the more tractable for it. In fact, it is apt to grow unmanageable unless cut back severely every year, but the large flowered type is not sufficiently hardy as a rule to make much cutting necessary, the frost usually giving more than the needed assistance. Frequently the clematis will make a fine show the early part of the summer, then suddenly wither and die, and examination usually shows a punctured stem and a pinkish worm occupying the hollow thus formed. When this happens there isn't much help for the top of the plant, though it will grow again from the root, but keeping a watch of the plant may prevent the invasion. The presence of fresh green sawdust anywhere about a stem is always a sign of mischief and if found before too large a cavity is made the worm can be removed or killed by running a wire up the hole and protecting the wound with absorbent cotton, a bit of gum or anything that will exclude air. Where wounds are near the surface of the ground, drawing earth up about it is often successful.

The Bignonia radicans is a very showy and effective vine when covered with the bloom in July. It clings 
to any stone, brick or wooden support and should never be pulled loose, as it will seldom attach itself anew. It is effectively grown as a hedge when the plants may be set three feet apart and trimmed up to the height desired before being allowed to branch. It will then throw out long, stout canes from this point which droop and present a mass of bloom in season. It makes a very handsome standard trained to a stake until of required height. The Bignonia has one great fault-that of spreading after the plants attain age; for this reason it should not be allowed to form seed as these will scatter in February or March and como up in unexpected places, and volunteer plants from the root are even more troublesome. If the plant could be set in a walled enclosure so as to be forced to remain there it would be a much more desirable tenant of the garden, but it is so fine when in full bloom that, for the time at least, one forgives it the sin of being too often in evidence.

The Actinidias are also very useful for covering arbors, porches or for positions requiring dense shade. For positions where a light vine is more suitable the akebia and large-flowered clematis are desirable and there are many charming annual vines which can be easily raised from seed sown either in the hotbed or in the open ground. One of the prettiest of all these is found in the Bryonopsis. This belongs to the gourd family, bpt has pale green, smooth, ivy-like foliage 


\section{MAKING OF A FLOWER GARDEN}

and is completely covered with small green fruit about the size of gooseberries, green mottled with white at first, but turning as they mature to a rich cardinal red. They appear at the axil of every leaf and when the vine has a chance to run along a horizontal wire they are lovely indeed. In the fall, sprays of the fruit may be brought in the house and will remain perfect for some time.

The Japanese morning glories are the most charming of the summer blooming vines. For best results one should buy the seed in separate, named packets and start the seed in flats or tiny pots in house or hotbed, soaking the seed in warm water until they sprout, then planting the sprouted seed in flats or pots, or, if the weather is warm, in the open ground. They should be planted on the north or west side of the house if one would enjoy their beauties, for if planted on the east or south the first rays of the morning sun will close the blooms before one has a chance to enjoy them. They require far more space than the common morning glory - five feet apart is none too much - and just as much upward room as one can command. On too low a trellis they will climb to the top and then droop over, hiding the lower blossoms, for the Japanese morning glory branches and blooms from the root up. Pure white blooms, five inches or more in diameter, double white, fluffy blossoms; white spotted and speckled with crimson; blue and crimson edged with 


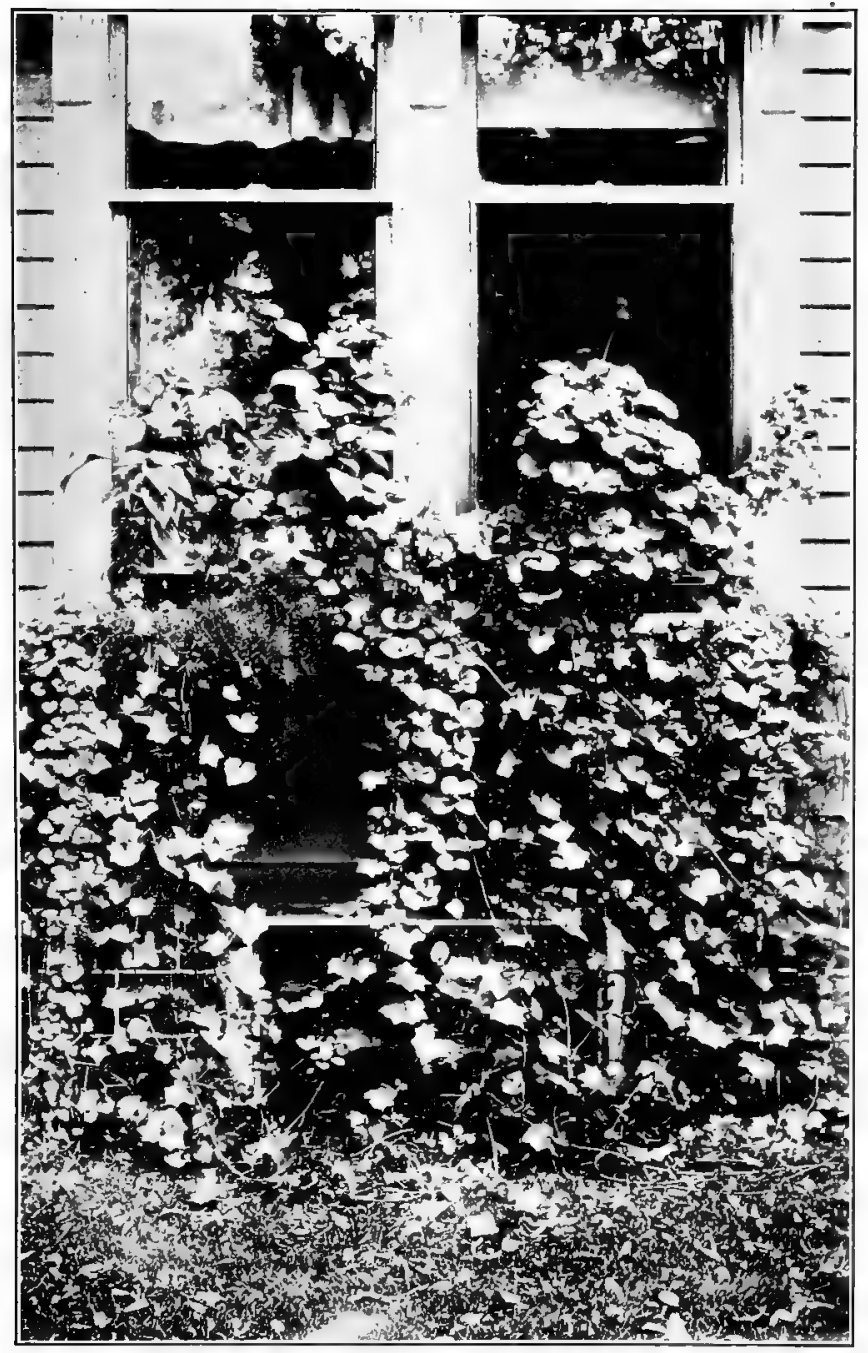

A THRIFTY WINDOW BOX TWO MONTHS AFTER PLANTING 


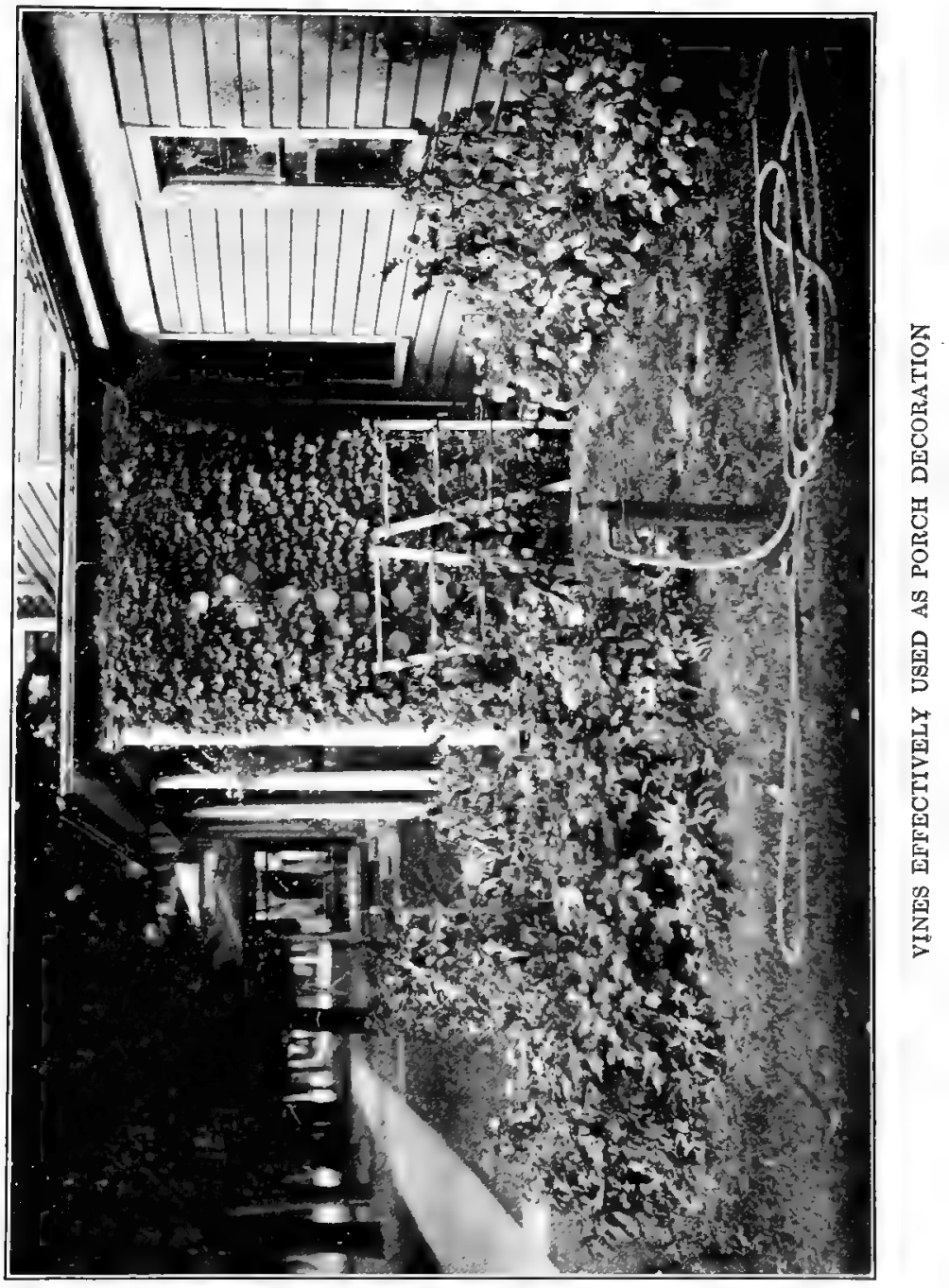


broad bands of white, terra cotta, steel grey; single and double blooms, all are found in this wonderful flower of the Orient. Good soil, cultivation and water, water, water, are the conditions that will produce the wonderfully large flowers that are known in Japan. I have raised Japanese morning glories that Japanese friends told me were larger than they grew, but I found it was water, and always water that did it.

Another most interesting annual vine is the momordica. This has especially beautiful foliage of the grape style, and long golden-yellow fruit that opens when ripe, showing an interior full of scarlet seeds. Other members of the gourd family are quite worth cultivating; one of the most effective vines $I$ ever grew was the orange shaped gourd. This has large, coarse foliage, but is exceedingly effective in a mural sort of way, and when grown across the front of a porch or pergola is wonderfully decorative.

No vine is so artistically beautiful as the Chinese wistaria when covered with its long pendent sprays of white or of lavender flowers. Unfortunately it is often a shy bloomer, requiring several years to come into flower; sometimes it never blooms. I have one myself that must be between fifteen and twenty years old and has defeated all efforts to make it bloom, though it grows rankly with a stem as thick as my wrist. Seedling plants are said to bloom seldom, so in purchasing vines of this particular sort one should 


\section{MAKING OF A FLOWER GARDEN}

see that they are getting plants from cuttings of blooming plants, if possible.

The adlumia or Alleghany vine is a delicate, fernlike vine, especially desirable for caskets and for positions where a slight tracery of green is desired. It is a biennial, forming a fern-like stool of leaves the first year, but rising into a tall, slender vine the second summer. It does better when planted on the east or north side of the house, as a hot sun burns the foliage. It self-sows and once established on the premises volunteer plants will be found from year to year which may be lifted the second season and planted wherever they are needed.

The wild cucumber, Echinocystis, is a very useful annual, especially for covering rough places or for porches, porch boxes or window boxes. It has one fault - the foliage turns yellow early in the season. For this reason its use in boxes should be temporary; just allowing it to remain until it begins to look shabby and then pulling it up and substituting something else, but while still fresh and green and covered with its delicate greenish-white sprays of flowers it is a very attractive and useful vine and as it comes up self-sown is always available.

There are several florist's vines which may be used as summer bedders and will prove both interesting and effective. The passion vine, Passiflora Pfordtii, is a beautiful thing, being covered the summer through 
with its large pink, white and blue flowers which spring from every leaf axil. It may be purchased in pots of the florists in the spring or old plants may be cut into short lengths and rooted in the hotbed, as they root very readily when given bottom heat and the protection of glass. They are fine for pergolas and desirable for porch and window boxes where a climbing rather than a trailing vine is desired. The passion vine will climb to the second story by mid-summer, blooming all the way.

A fine vine which has given me much pleasure is the Aristolochia elegans. This cannot, usually, be obtained of northern florists, but must be purchased of the Florida greenhouses, but it will well repay considerable effort to obtain. The leaves of the Aristolochia elegans are thick and leathery and the flower very striking and novel-a disc-shaped bloom about two inches in diameter of a creamy color overlaid with a network of reddish, purplish brown. It blooms profusely and in fall can be cut back and wintered in a dormant state in a warm cellar. A table back of the furnace suits it, or it may be brought into the conservatory for winter blooming.

If one has the convenience of a suitable winter storage plant room in the basement, then one's garden may be greatly enriched with plants from the tropics and semi-tropical parts of the country. Some of the southern trumpet vines are exceptionally beautiful 


\section{MAKING OF A FLOWER GARDEN}

and there are many other tropical vines well worth trying, as well as many shrubs and bedding plants; the crape myrtles, the oleanders, hibiscus and many, many others.

For window boxes there is nothing more daintily graceful than the little manetta vine with its foxgloveshaped blossoms of blue, of pink and of white. It is easily raised from seed sown in boxes of fine soil in house or hotbed in February or March. At the same time one may start seeds of the thumbergia, which requires similar treatment. 


\section{CHAPTER XII}

\section{THE ROCK GARDEN}

THE rock garden is a sort of edition de luxe in the garden repertoire, that is, it is so to us of the Middle West where stones and rocks are about as rare as rooks eggs, but in New England they may often be a "virtue of necessity." It is a fascinating necessity since there are so many delightful things that are especially suited to a.rockery; things that one seldom sees in the garden proper, while most of the common things, annuals, perennials, shrubs and small trees, all may be colonized in the pockets and comfortable crannies of a generous rockery.

A rockery, to be at its best, should never be a mere tumulus of stones, though even that makeshift may be attractive with proper planting, but should have its beginning in some natural way, starting at some fixed point, as a group of trees which may be planted for the purpose; a stone wall or a building, or one great boulder may be the inception of the whole. The rocks at the beginning should be large and be so placed as to appear to crop out of the ground; they may di- 


\section{MAKING OF A FLOWER GARDEN}

minish in size and height as the edge of the rockery is reached, but nowhere should they deteriorate into a mere pile of stones. The best location is one extending from east to west so that a planting of tall shrubs or trees-as the larches, tamarax and tamarisk - may be made on the north side where they will not shade the lower planting. All tall shrubs and perennials must be on the higher parts of the rockery, the low-growing and creeping things being nearer the ground. Suitable pockets of soil must be provided and in the case of shrubs and deep-rooted perennials the pockets should extend to the ground. Certain rock-loving plants will do well in shallow pockets, but the soil must be of the best to start with-a warm, fibrous loam, well enriched with old manure, for obviously, the soil cannot readily be changed once the rockery is established, but must depend upon such top dressing as can be given in fall and spring for renewal.

The rockery will afford spaces of sun and shade, congenial for many sorts of plants; there should be moist hollows where ferns and things of the wild-wood will thrive. On the northern side, in the shade of the trees many woodsy things can be colonized-the bloodroot, trillium, hepatica, rock-loving columbine, ferns and the like. On the sunny edges many of the springblooming bulbs may be grown and will make a lovely ribbon of color in the early days of spring-hya- 
cinths, crocus, scillas, primroses, pollyanthas and many others that come almost as soon as the bluebird does. These early bulbs that have bloomed in the house in winter may be planted out in the rockery the next fall and will give good returns for years to come.

One of the earliast plants to bloom, often appearing in early April, is the saxafraga (Megaseas). These have immense leathery leaves of deep green and large clusters of pink, deep rose, rosy-erimson and of white flowers that are very attractive and showy, and the plants are very hardy and entirely free from. insects. Once established they require no further care. The tall-growing saxafragas are also very desirable for the rockwork, especially saxafraga pyramidalis, which defines itself clearly against the grey of large boulders. The rock-loving columbine is a beautiful thing planted on the west side of a big, grey boulder where the sun can etch its shadow on the rock. All the Sedums are at home in this environment and increase in size and effectiveness from year to year. Some, as the sedum acre, or golden moss, are lowgrowing forms, hugging the rocks closely; there are many forms of these; pink, white, yellow flowered, and all are good.

The earliest of the low-growing plants to flower is the arabis or rock cress; this soon covers the rocks with its-silvery-green foliage, starred in April with 


\section{MAKING OF A FLOWER GARDEN}

white. The acæna is a pretty thing for sunny positions, with bronzy evergreen foliage and showy crimson spines. In shady spots the ajuga and the alchemilla may be planted and sweet alyssum will be at home anywhere that the sun can warm and welcome it.

The aubretia-false wall cress-is another pretty dwarf rock plant with silvery green foliage and bright, reddish-crimson flowers in spring. The callirhoe is a showy trailing plant with finely divided foliage and showy, saucer-shaped flowers of bright, rosy crimson which cover the plants throughout the summer. The English daisy, Bellis perennis, is especially suitable for sunny edges and for growing on the less pretentious mounds of stone. The draba is another dwarf-growing rock plant with white flowers and the Epimediums (Barren-wort; Bishop's Hat), also dwarf, have interesting leathery foliage that turns to beautiful tints of color in autumn and shows a greater range of color than most rock plants; crimson and yellow of the Epimedium alpinum, the rosy red of Epimedium musschlanum, a pure white, yellow and rich violet of violacea. Then there is the fern family with many interesting members, not the least interesting of which are the English ferns, Scolopendriums in variety, the maiden hair ferns, the Aspleniums, with their odd criss-crossed pinnea, and all the well-known native ferns of the local woodland which 
may be had for the taking. The well known groundsell or ivy and the Kennilworth ivy are too well known to need more than a mention and each adapts itself to a home on the rockery.

For taller growths one may use the orobus with its bright blue pea-shaped flowers in May and June. The prunella has round heads of purple flowers all summer and the rexia or meadow-beauty has bright rosypurple flowers all summer, and the tunica-a tufted plant with light pink flowers produced all summerindeed, there is an endless wealth of suitable plants for a rockery and one need not be as restricted in choice as in more formal planting. For tall plants I like the foxglove exceptionally well, as planted singly it silhouettes so beautifully against a background of rock, of greenery or sky; this also is characteristic of the purple cone flower or rudbeckia.

If possible, the rockery should contain several hollow, cup-shaped stones that will afford bathing places for the birds, or bathing and drinking places can be hollowed out in the soil and lined with wire and cemented. Where the rockery has a high point a little water can be conveyed to this highest point by pipe or hose and so form a miniature cascade to trickle down the face of the rock into a succession of shallow stones, making grateful bathing spots for the birds who will bathe as well in its spray as in the pools 


\section{MAKING OF A FLOWER GARDEN}

it forms. Jutting out from crevices along its path one should plant the moisture loving ferns.

In sunny spots one may colonize a few cacti which will prove interesting, and become, if the hardy species are selected, permanent members of the rock family. 


\section{CHAPTER XIII}

THE WATER GARDEN

THIS affords one of the most fascinating forms of gardening and one of the simplest and least exacting, for, once put into operation in the early spring little further attention is required. Unlike the flower garden with its constant call for cultivation, tying up of plants, watering and general supervision, the water garden will need little more than to turn on the water as the water in the pool evaporates and, once or twice during the summer, to thin out the lily pads so that they do not crowd.

Where one is so fortunate as to have a stream of water flowing through the grounds, as is often the happy instance in New England grounds, one can arrange an overflow in a low bit of ground by hollowing out and puddling with clay so that a most naturalistic appearing pool will result. The edges should be banked with rocks and planted with moisture-loving plants, such as the iris, planted in clumps. The iris appears to such fine advantage in such situations that it is worth constructing a waterside garden for 


\section{MAKING OF A FLOWER GARDEN}

its benefit alone; they should be planted in clumps, some little distance apart and not in formal lines, for realistic effect.

Where there is no natural water supply, resource must be had to the artificial pool of cement, and such a pool is indispensable in all formal gardening, and makes an objective point for the meeting of garden paths, or the end of a walk that is not supplied by any other form of bed or ornamental structure.

The construction of cement pools is so simple that any one handy with his hands can construct one, so that where home talent is employed the expense is not of serious moment. The dimensions, horizontally, will depend upon the room at command and the amount one wishes to expend, and, of course, upon the location of the pool. The depth is always practically the same-two feet for the growing of nymphæas of various sorts, eighteen inches being sufficient when one prefers to grow the lotus. Where the pool is to form the center of a more or less formal garden of moderate extent, a diameter of twelve feet will be an excellent size, and a round pool is preferable to a square or oblong one. For isolated pools on the lawn or at one side, a larger pool of twenty feet long by fifteen wide will give room for the growing of a greater variety of lilies and a still larger one will admit of the growing of the Victorias, especially Victoria Trickeri, which does not require artificial heat, but 
may be planted out in open pools when the nights are warm-early in June, usually.

The simplest way to construct an artificial pool is to mark out the circumference on the ground and then to dig a trench two and a half feet deep and as narrow as can be handled, making the sides as smooth and even as possible. Concrete will then be poured into this, using rather small gravel in the mixture and paddling it away from the sides so that in setting the concrete may have a smooth, firm surface. After the concrete has become perfectly hard (and sufficient time must be allowed for this part of the work) the inside of the pool may be dug out down to the bottom of the concrete wall and a cement floor laid, great care being given to the joining of the floor and wall, for it is at the angle of floor and wall that trouble from leakage usually occurs. It is better to cove this angle and leave the work as smooth as possible. If this is done, both in the rough and in the finishing coat which is applied over all, any cracks which occur in future will be easily located and repaired. Roughness here frustrates all attempts to locate the trouble and necessitates the going over the whole angle if repairs are needed.

As the top of the pool should be a fow inches above the ground-just how high being a matter of tasteforms will be required for this part of the work or concrete blocks shaped to the curve of the circle can 


\section{MAKING OF A FLOWER GARDEN}

be used, or, if one prefers that effect, the top can be laid in cobble or rocks. Either effect will be good, but where smooth concrete is used in other parts of the garden, walks, walls, seats, etc., the curb would better conform to these.

In the two-foot pool about one foot of good soil is required, marsh earth and well-rotted cow manure being the best combination. Over this, after the lilies are planted, an inch of clear white lake sand should be spread. This will disappear during the summer, but may be resurrected again the following spring by peeling off the quarter of an inch of muck that will have formed from the decay of vegetable matter and the dust that has settled in the water.

It is not necessary, however, that this foot of earth be used as the lilies may be planted in large boxes of cedar or galvanized iron tubs instead. These need not be over a foot deep and should be filled with the same soil used for the pool. There are certain advantages in this mode of planting as it makes possible the inspection of the bottom of the pool should a leak occur. Leaks in a well-constructed pool are not usual, but do occur sometimes, and in a pool filled with earth it is very difficult to repair them when full of growing plants. They seldom occur in the floor of the pool, but rather at the angle and in the wall, and when necessary to deal with them a trench must be dug around the wall, inside the pool, first letting out all 
the water, until the trouble is found. Of course where the lilies are in tubs the matter is simple, as a few hours' work will put things in order again. Small cracks above the earth line and in the wall are often successfully handled by painting with white lead. These are caused, of course, by frost, but properly protected in winter, frost will never find its way into the interior of the pool. Winter protection consists of letting out the water and filling the pool with dry leaves heaped high. Over these a cover of canvas or lumber must be placed, the center being sufficiently high to shed water freely. Two oblong structures of matched boards, two feet longer than the pool and as much wider as half the diameter, the center and ends resting on stout supports, and securely attached at the center, make a very satisfactory cover as it can be stored against a wall in a barn or other convenient place, while a round cover is very awkward to house anywhere.

There are so many beautiful varieties of water lilies offered by the florists who specialize in this form of plants that it is difficult to make a choice. Perhaps the best selection for the beginner would be one or two plants each of Marliacea rosæa, and Marliacea chromatella, both hardy nymphæas, constant and prolific bloomers, and perfectly hardy. They come into bloom early, usually showing buds when the leaves are removed from the pool in the spring, though there 


\section{MAKING OF A FLOWER GARDEN}

is no water in the pool, and the ground but slightly damp. Marliacea rosæa is a beautiful pink flower five inches in diameter, and Marliacea chromatella a somewhat smaller, lemon yellow flower. The finest white is Nymphæa tuberosa Richardsoni, but unfortunately it is a rather shy bloomer when grown with other varieties and at all crowded. It is by far the handsomest of all the day blooming hardy Nymphæas. But one should not confine the planting to the day blooming Nymphæas alone, as these close their flowers at about four o'clock or earlier in the afternoon, just at a time that they would be most appreciated. However by planting a few night bloomers - which open early in the evening, remaining open until late the following morning, blooms will be open at the most interesting time of the day. These night bloomers are of the tender variety and must be purchased each year of the florists or wintered in a warm greenhouse, but they well repay the additional care and expense, as they much exceed in size and beauty the hardy Nymphras, being often twelve and fourteen inches in diameter and of surpassing beauty of color and form. The blue Nymphæas are especially admired and these are easily grown from seed planted in shallow, water tight dishes of soil covered with an inch of water and placed in the hotbed close to the sash. The seed should be scattered on top of the water, when it will sink to the bottom, germinating in about six days. 
When the little plants are large enough to handle they should be pricked out into inch pots and plunged in a dish of water and grown on until June, when they may be planted out in shallow water in the pool. They will bloom the first year, but the blooms will be small. The second year they will have attained size and blossoms ten to twelve inches will be produced.

The various lotus are easily grown from seed, in much the same way, but as the seeds of the lotus are large and very hard they must be filed or sandpapered until a white spot shows on the side of the shell; treated in this way and placed in a warm hotbed nearly every seed will produce a plant. Seeds of most of the best varieties of lotus can be obtained of water lily specialists, and as the seed can be purchased at from fifteen to twenty-five cents a packet, and the growing plants cost from three to six dollars each, it is quite worth one's while to experiment with the seed.

It is not best to grow the Nymphras and lotus in the same pool. For one thing the lotus require a more shallow water than the Nymphæas, not more than six inches being desirable, while the Nymphæas require twelve for best results. Again the root growth of the Nymphras is entirely distinct from the lotus, being club formed and not extending far from the original point of planting. For best results all small plant buds should be removed from these main roots each spring and the strength of the root given to the pro- 


\section{MAKING OF A FLOWER GARDEN}

duction of one or two strong plants. On the other hand the lotus forms a rhizome root, of immense proportions. One lotus root planted in a twelve-foot pool will circle the pool in two seasons, hugging the wall and sending up tall leaf scapes and blossom stalks at intervals of a foot or eighteen inches, completely obscuring a view of the floating Nymphæas.

If one wants to grow them in connection with Nymphæas then it would be well to place another wall in the center of the pool three or four feet in diameter and make the earth in this higher than in the rest of the pool and in this plant the lotus; they will then make a beautiful center for the pool and will not interfere with floating lilies.

If one wishes to stock the lily pool with plants of home growing, then only so much water should be let into the pool as will saturate the soil and leave just enough water on the surface to float the tiny pads of the seedlings. More must be added very gradually and carefully as the plants increase in size and length of stem. In planting the seedlings, merely press the roots down into the sand, and if inclined to float at first, place a little stone over each root.

Water can be brought into the pool either by piping or by means of a hose from whatever water supply one has. The letting out of the water, however, requires a drain of tile carried from the lower side of the pool to a main drain or to a pit filled with gravel 


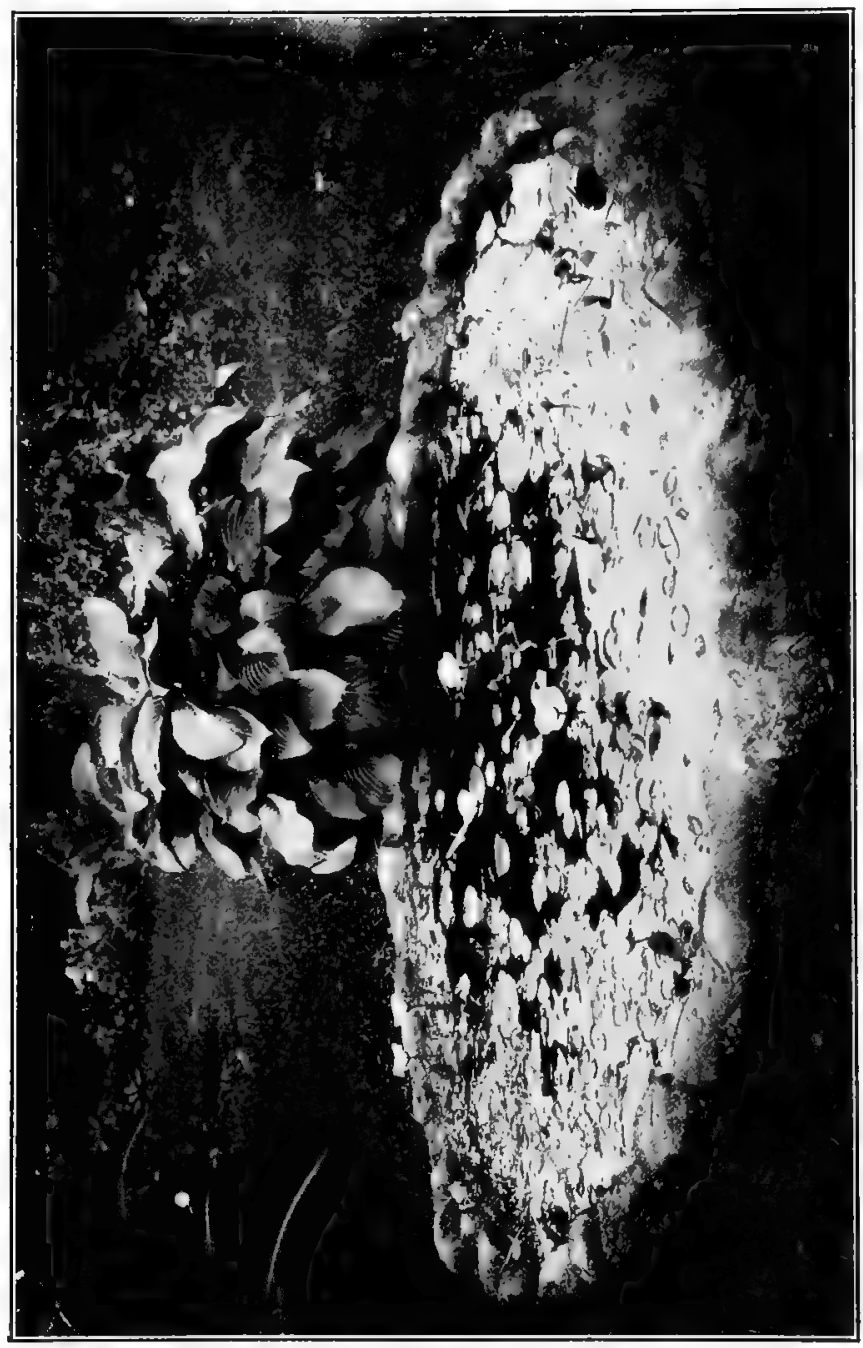

| 


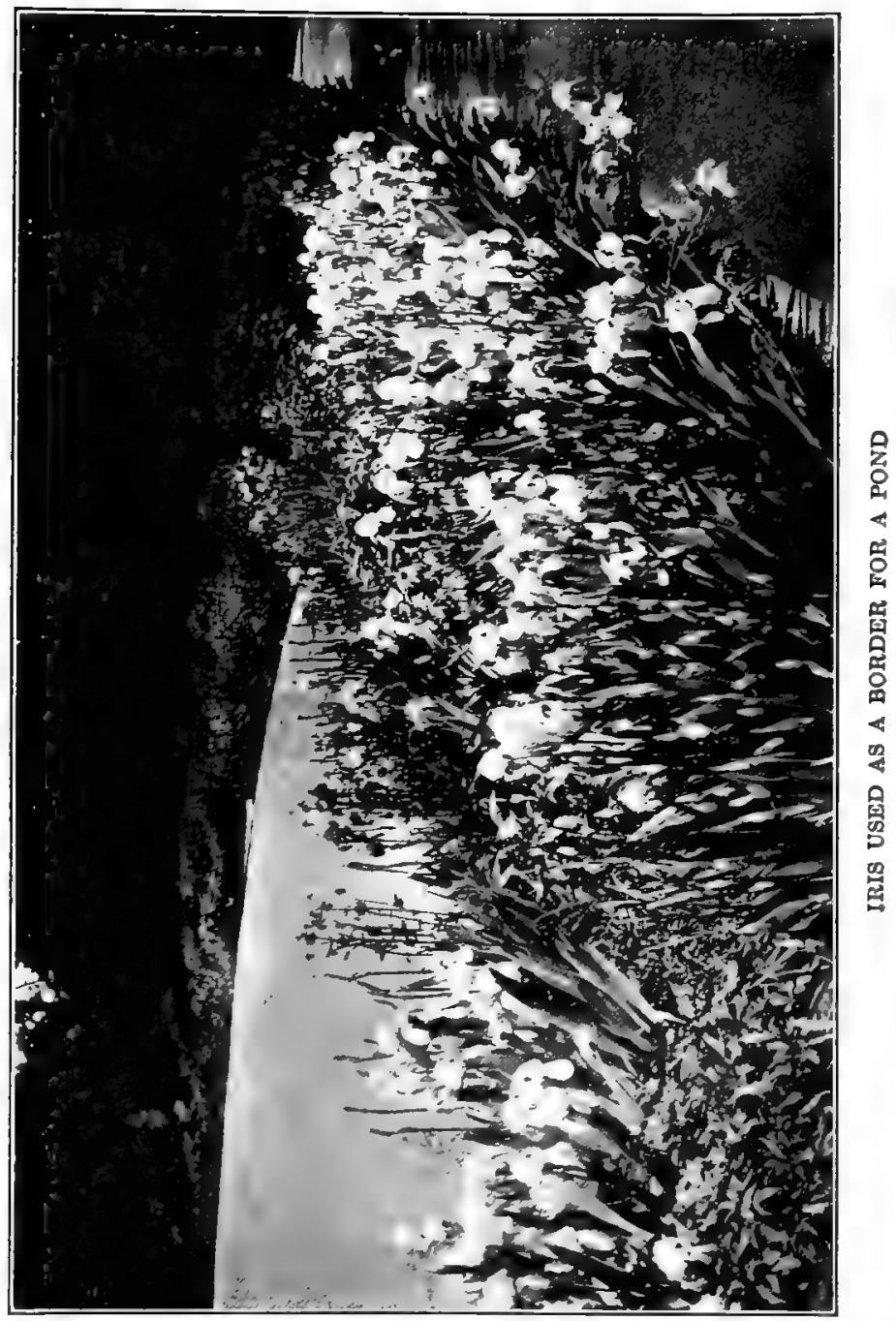


at a little distance. It should enter the pool on the bottom by means of an angle tile, the opening of which should be level with the floor of the pool and well cemented into place. This opening, a three or four inch tile, can be closed by a wooden plug, also cemented in, through which a one inch hole is bored to be closed by an inch wooden rod extending above the water. If a ten or twelve inch tile is placed above this to keep back the soil it will be found that it makes a more reliable stop than a plumber's trap, which is always liable to leak and give trouble. The swelling of the wooden rod hermetically seals the opening and in fall, or whenever it is desired to let out the water, it is easily removed by passing a chain around it and lifting it with a lever and fulcrum, as a crowbar and a block of wood.

Water lilies are often troubled with the grey aphis or plant lice; these are sure to appear in August if the plants have been allowed to become crowded. They are absolutely deadly, both on the Nymphæas and the lotus. Nymphæas can be sprayed with kerosene emulsion to eradicate them, but kerosene must never be used on the lotus, nor can it be used on pools containing gold fish. For this reason the pads must not be allowed to crowd until they stand out of water. When the lice do appear the remedy is to spray with water at a hundred and forty degrees for one thing, and to get into the pool, either by wading or by means 


\section{MAKING OF A FLOWER GARDEN}

of a long ladder laid across the pool or resting on a tile in the center and covered with a board, and remove every leaf above water and if necessary the buds and blossoms also.

It is surprising how quickly they will replace themselves so that the pool is not rendered unsightly for more than two or three days. A better way, however, is to remove all the faded and old leaves frequently so as to leave open places between the plants all the time; the effect is much better than of a pool crowded with leaves. This cannot be done in the case of the lotus, and removing the lice by hand has to be resorted to as they quickly ruin the plant if allowed to increase.

A few gold fish should always be kept in the pool as they act as scavengers, destroying the larvæ of the mosquito and other insects and are of themselves objects of much interest, becoming very tame and coming up to eat from one's hand if fed regularly in the same place. Though they find sufficient food in a well stocked pool they are very fond of the bread which they eat from one's hand, swimming in and out between one's fingers. 


\section{CHAPTER XIV}

\section{THE OLD-FASHIONED GARDEN}

THE old-fashioned garden of hardy perennials, with its rows of hollyhocks, its beds edged with spice pinks, its Sweet Williams and none-so-pretty has all but disappeared from the village home, giving place to the conventional bed of cannas, salvias or geraniums, but is appearing in a much developed, glorified form in the country homes of the well-to-do, few of which are to-day without their old-fashioned or "grandmother's garden." In some of these gardens the floral display rivals in perfection of bloom and glow of color any achievement of the showy bedding plants, many of the perennial flowers-larkspurs, foxgloves, Canterbury bells and the like-being grown in pots in cool greenhouses until ready to burst into bloom, when they are planted out to take the place of hardier perennials which have but that day finished their season of bloom. In this way an unbroken succession of bloom is produced, but it seems to me that the real spirit of the perennial garden is lost, for the deep, underlying principle of the perennial garden is per- 


\section{MAKING OF A FLOWER GARDEN}

manency and age. Just as we value an old article of silver or ehina or furniture that has been handed down from mother to daughter for generations, over a similar article that has just been bought from a dealer, even though it may be of equal antiquity and undoubted genuineness, so the old-fashioned garden should have its sentiment, its legends, to have the real old-time spirit, and although we cannot all inherit old plants and gardens, we can, at least, establish those that will in time come to have a beauty and dignity of place and association.

The hardy perennial plants are the garden's most profitable asset, increasing in value from year to year and earning a rich increment of size and progeny.

I think the inception of a hardy garden should have much to do with sentiment; that one should first plant those things which most appeal to one and those which are in any way associated with one's intimate life. Plants gleaned from the gardens of dear friends, especially those who no longer meet with us, have a subtle charm quite distinct from those which merely represent a financial transaction.

There are two points to be considered in the laying out and planting of a garden of hardy plants; one that the garden must be allowed room to grow-it should not be planted in a strictly circumscribed space, so that the first planting sets the limit for all future planting, but rather, it should be so arranged that 


\section{THE OLD-FASHIONED GARDEN 147;}

beds may be lengthened or new beds added as the occasion arises, for all, or most, perennials increase, either by self sowing, by off-shoots or by root division, and a very modest planting to-day will be the nucleus of an extensive one later on. Secondly, a large num. ber of plants of one variety is far more effective than many kinds of plants singly or few in number, and the edging of beds of tall perennials with low-growing plants is distinctive of all old-fashioned gardens and adds a special charm to the planting.

If, in the beginning of our hardy garden it is not practicable to plant all the various sorts by the dozen or score, then one should use, judgment in planting what is available. The important ones-those that will remain undisturbed for years until in time they attain noble proportions, like the dictamnus, which is a plant of generations rather than of years-should not be placed as near neighbors, so that in time they will encroach upon the room needed by each other, but should rather be neighbored by shorter lived or less important plants which one will not hesitate to remove when their room is needed by the more important plant, and the idea of permanence should not be lost sight of. One should have a clear idea before planting anything, just what the effect will be. Many perennials have no objection to frequent upheavals, but to others it means a check in growth and often complete dissolution. Color incongruities are more 


\section{MAKING OF A FLOWER GARDEN}

often disastrous than any other form of incompatibility. I recall a planting in my own garden that resulted most disastrously and might just as well have been averted by an instant's thought. In this case, having a surplus of Oriental poppy plants to dispose of in a hurry, several were set in a border containing a fine plant of dictamnus; the result when the two bloomed together was something to make a flower lover mourn; of course in this case the remedy was to remove the poppies, but two or three weeks' discord was created in the garden by mere thoughtlessness and I dare say the plants are still gossiping about it.

In considering color juxtaposition it should be borne in mind that when in doubt one should always use white. White is the great peace-maker and can be introduced with good effect almost anywhere. It is especially good with scarlet and where two inharmonious shades of red have been inadvertently placed side by side, the introduction of white may relieve an embarrassing situation. Almost all shades of yellow harmonize with blue, mauve with pink. Blue planted in the rear of the garden increases the apparent distance and extent of the garden while white brings the planting nearer, lessening the apparent size of the garden.

Many plants are at their best in long rows, rather than in massed beds; the hollyhock and foxgloves are good instances of these. The garden spiraea is good 


\section{THE OLD-FASHIONED GARDEN 149}

in long rows used as a background for lower growing plants such as the lychnis and feverfew. A bed that always affords much satisfaction at its time of bloom has a close row of aquilegias in the front row which bloom first; back of these, coming into bloom at the same time is a row of scarlet lychnis and white feverfew, alternated, and backed by the tall garden spiraea; the effect is delightful and after these have faded the last and rear rows of physostegia finish up the color symphony of that bed for the year.

The ulmaria is a perennial plant of the spiraea family that is beautiful when grown in long rows. This combines well with scarlet and may be edged or bordered with any good scarlet flower blooming at the same season. The ulmaria, to be at its best, should be lifted and divided every third year. Unless this is done the plant makes so dense and woody a root growth that no moisture can penetrate it and only scant and inferior bloom is produced, but if divided and the plants set eighteen inches apart in good soil and freely supplied with water during the growing and olooming season, it will be one of the marked features of the garden.

German iris is another plant requiring frequent division and resetting in good soil, though it need not be reset more than once in three years, unless it shows signs of failing in bloom. Each clump taken up should have all the old woody root discarded, only the 


\section{MAKING OF A FLOWER GARDEN}

new growth with strong, live eyes being retained, and these may be set in a clump or circle, the roots turning outward, so as to form a fine clump when in bloom, for a strong clump should be aimed at that the effect may be good the first year after planting. Lift and divide in August or before new growth starts.

Hardy phlox is another of the perennials that requires frequent dividing. The roots may be lifted every second or third year, according to the growth they have made, and pulled or chopped apart and reset singly in fresh soil. The dictamnus on the other hand should never be disturbed, once it is planted, but top-dressed with old manure in fall or spring and this worked into the soil; that is all the care this fine plant requires.

The aquilegias require little care, once established, beyond keeping the weeds away and the soil, which should approach that of the woods as nearly as possible, mellow and moist. The aquilegia self-sows and the little seedlings may be lifted and easily transplanted, but the old plants do not transplant very well and should be left undisturbed if possible. The double blue and white columbine, however, may be lifted by passing a spade down well below the roots and transferring it to a new position. Never pull up a plant, nor dig it out with the trowel if there is any doubt of its transplanting safely, but lift it on the spade with all the earth that belongs to it and trans- 
fer it to a hole already prepared, in one operation. Foxgloves, which are often hard to transplant, will do nicely if moved in this way.

Paeonies are of the plants which should not be disturbed unless it is necessary. If not blooming well and remedial measures have failed it may be well to lift, dividing if the clumps are old and large and to reset in a more favorable location. Failure to bloom is sometimes caused by too deep planting (there should not be more than two inches of soil over the top of the clump), by sour soil-remedied by application of lime; by poor drainage-indicated by sour soil; lack of sunshine, or-and this is almost always the real trouble-lack of sufficient water when the plant is making growth and developing its flowers. It will frequently be found that paeonies that have had a poor blossoming season, followed by a rainy summer, give abundance of fine flowers the following season. Another thing that often injures the paeony is cutting off the foliage before it matures and dies a natural death; this should never be done.

Nearly all of the old-time garden favorites have been greatly improved in the last ten years. Especially is this improvement noticeable in the hollyhock and in the paeony. The new double hollyhock, Newport pink, is an exceptionally beautiful flower, perfect in color, flower and manner of growth. A long row of them in full bloom in July and August is 


\section{MAKING OF A FLOWER GARDEN}

worth going a long way to see. The hollyhock requires little care in general, but of late years what is known as the blight has much injured the plantings, unless treatment with bordeaux mixture has been given early in the growing season, as soon as the stalks begin to form, and repeated at intervals on the underside of the leaves until the blight has been checked.

Both the old-fashioned larkspurs and the newer named delphiniums, especially the Gold Medal delphiniums, are practically everblooming, for if the plants are cut back to the ground when through their first season of bloom a second erop of flowers lasting well through the fall will be produced. The delphiniums may be planted outdoors in May in the vegetable garden and cultivated during summer and lifted and planted where they are to remain in the fall or the following spring. Usually they will give single spikes of bloom the first year so that one may make selections of the more desirable sorts, though there are few discards in this beautiful flower which often grows five or six feet tall with spikes of beautiful flowers from a foot to eighteen inches long in all the shades of blue from the palest azure to the deepest ultramarine, with pink, white, black or bronze eyes. Surely no flower of the garden is more worthy of extended cultivation.

Of the Sweet Williams no sort has attracted more favorable attention than the Newport Pink, a distinct 


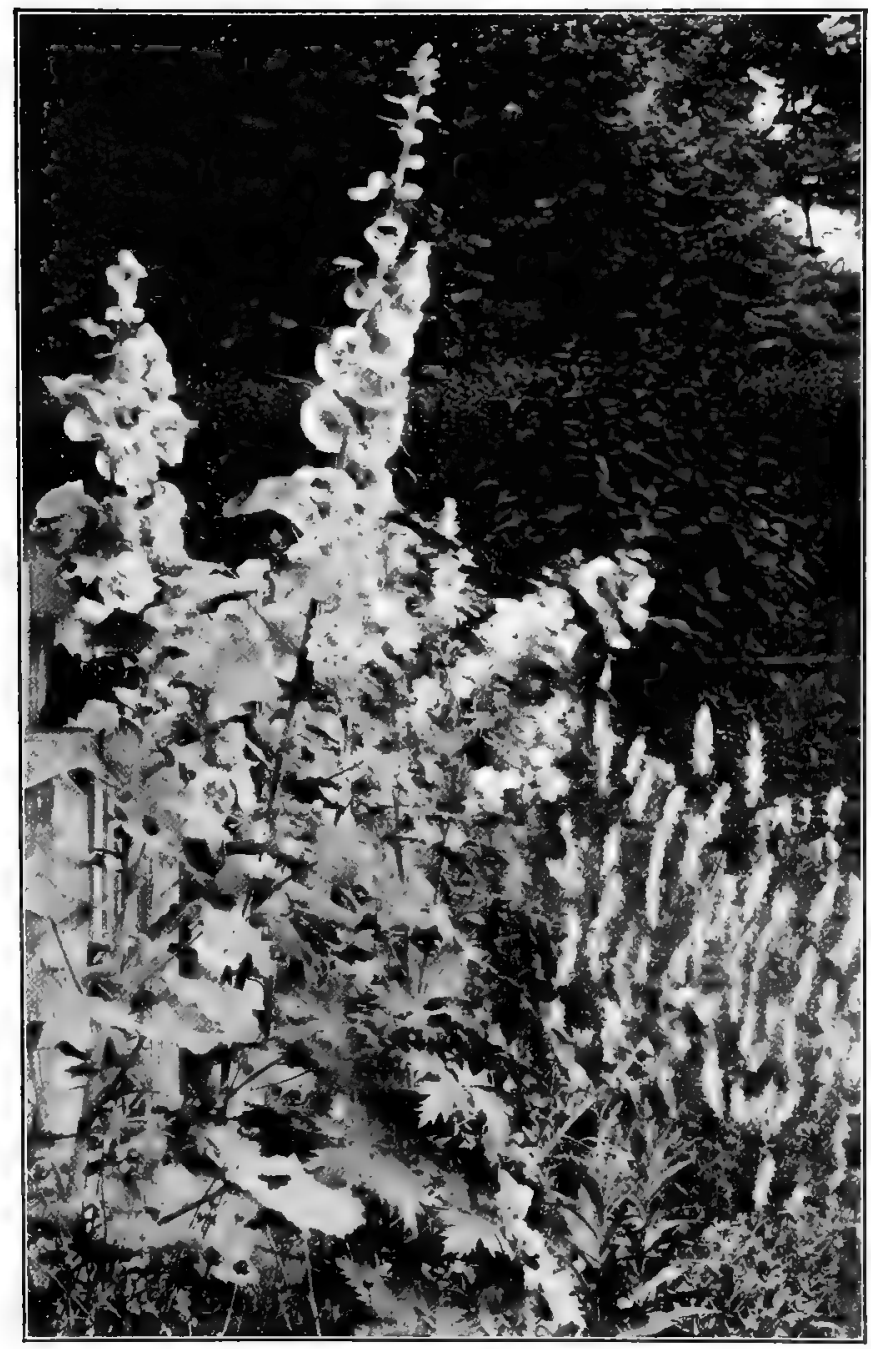

A HARDY BORDER OF LARKSPUR AND HOLLYHOCKS 


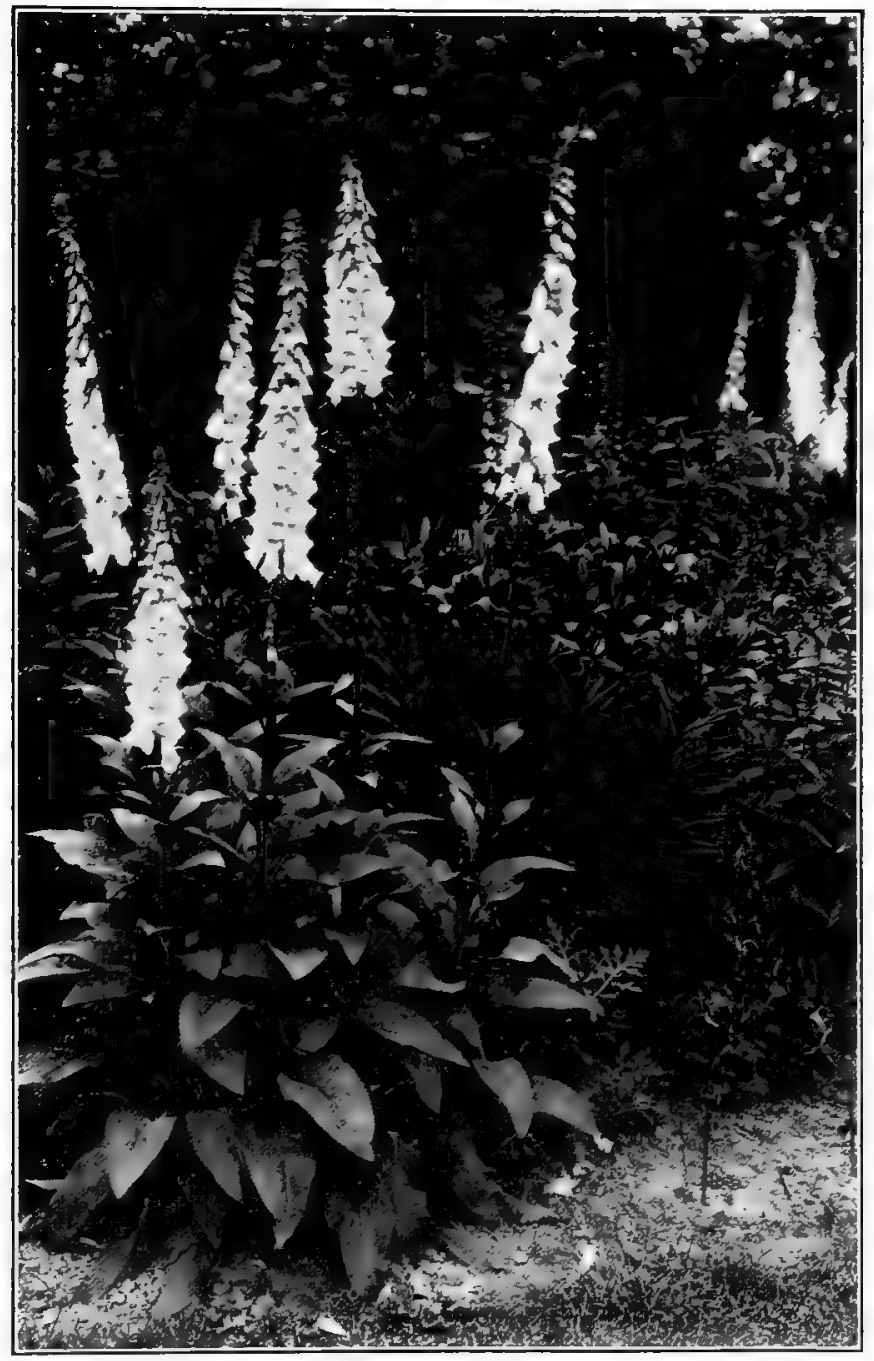

FOXGLOVE PLANTED AGAINST A BACKGROUND OF SHRUBBERY 
new color which originated in one of the famous gardens of Newport. It is what florists call a watermelon-pink and is an admirable sort for bedding and massing. The ever-blooming hybrid Dianthus latifolius atrococeineus is another distinetive sort, blooming the first season from seed, and is a continuous bloomer. The color is an intense crimson scarlet always attracting attention in the garden. It makes admirable edgings for beds of taller plants and a fine border for lily pools, where it may be alternated with sweet alyssum with excellent effect.

A chapter on hardy perennials cannot, in the nature of things be exhaustive when included in a general garden book; it can only touch here and there the high lights of the garden's catalogue, but certain things stand out conspicuously, either because of their merits or popularity, and call for more than a passing mention. Of plants which seem especially attractive and winsome none appeals to me more strongly than the anthericum or St. Brunos lilies, whose waxen bells, like miniature candidum lilies, are produced on eighteen inch spikes in May. One should plant these, not singly but by the dozen, and give them a little space by themselves, as when crowded by the too-near presence of other plants they will not thrive, being not at all assertive of their rights. They like a moist, mellow soil in a semi-shaded situation. 


\section{MAKING OF A FLOWER GARDEN}

A position where they can have the morning sun will do admirably.

Blooming at the extreme opposite of the garden year, in October, the Japanese anemones give abundance of beautiful, daisy-like flowers at a time when other flowers are scarce. These require a somewhat shaded, protected position and a moist, woodsy soil for best results. The plants increase by underground growth, the rhizome roots spreading rapidly through the bed and throwing up numerous plants. For this reason they should be disturbed as little as possible as it is diffeult to cultivate the ground without destroying many of the plants, so that it is best to wait until growth begins in the spring before working over the beds.

The double forms are the more beautiful and the white is, perhaps, the loveliest of the sorts, though the soft rose-pink, and silvery-rose are each beautiful. Indeed one could scarcely do better than to plant the entire collection of anemones, for few flowers surpass them in delicate beauty. A long border planted to the several varieties is a distinct acquisition to the hardy garden.

In semi-shaded spots in the garden the astilbes give beautiful spikes of feathery pink and of white flowers. These are the astilbes forced by the florists for Easter, and are not at all hard to grow in the hardy border if given good soil and sufficient water. 


\section{THE OLD-FASHIONED GARDEN 155}

For late fall flowering the hardy chrysanthemums are indispensable. They should be planted in a warm sunny position, beside a south wall of a building if possible, as they perfect their flowers late in October, often being still full of bloom when the first snow storm whitens the ground. For this reason the brighter colored sorts are preferable and there are many shades of pink, red, bronze and yellow to be had, all desirable and of easy culture. The Shasta daisy, which belongs to the same family but blooms in July and later, is easily raised from seed, often blooming the first year. The roots increase in size rapidly and may be lifted every spring and reset, so a planting of an initial dozen the first year will give several score of plants the succeeding summer. They may, be planted in any good soil in a sunny situation and will take care of themselves. A new Japanese variety, Nipponicum, blooms in September and October on two foot stems with large, pure white flowers. 


\section{CHAPTER XV}

\section{HARDY SHRUBS AND TREES}

THe planting of hardy shrubs and ornamental trees should be one of the earliest undertakings in the development of a new home. Most hardy perennials and all bulbous and annual plants give immediate results, but these larger, stronger growths require time to adjust themselves to their new conditions and develop into effective size and florescence. There are few places so small that room for a few shrubs cannot be found, or so large that some effective sorts may not be selected to add beanty and grace to the landscape.

One very effective use of shrubbery consists in banking about the base of stables, barns and other out-buildings. This is especially desirable when these buildings are, as is usually the case in the small place, in plain view of the house. A successful planting of attractive shrubs in such locations not only serves to mask an otherwise unattractive object, but also brings into the outlook from the windows, a wealth of beautiful form and color throughout the various 


\section{HARDY SHRUBS AND TREES}

seasons of the year. For such positions it is desirable to select plants that will give the longest season of bloom; those which have attractive foliage of an ornamental nature or those which are attractive with bright berries or colored bark in winter. Evergreens are always desirable and may be used as a background for shrubs bearing bright berries or bark with charming effect.

The objection is often raised that the number and size of the doors of a barn or stable leave little room for planting, and this is, in a measure, true, but if, instead of opening the doors back against the barn they are merely opened at right angles and a post set for them to swing against, or if they can be made to slide on hangers, a very appreciable difference in the available planting space will result. Usually it will be found that quite tall shrubs can be used here.

A rear fence, a division line between lots where it is not desired to have the lawns continuous, an angle in a building the harsh lines of which need softening, all afford excellent opportunities for the planting of shrubs and trees.

One of the most successful uses of flowering trees consists in using them to top a high board fence or brick or stone wall, where they are especially effective when in bloom. For this purpose it is better to select those which make a crown of branches rather than those which are clothed with foliage from the ground 


\section{MAKING OF A FLOWER GARDEN}

up. Cercis canadensis is an excellent, medium-sized flowering tree, completely covered in early spring with wreaths of deep pink buds. The dogwoods are delightful trees for the purpose and all of the flowering peaches, crabs, cherries and plums, especially the double-flowered ornamental sorts. Aralia spinosa is an enormously effective thing when, in mid-summer, its gigantic leaves are crowned with great masses of greenish white flowers and always the tamarix' feathery foliage and dainty bloom is a joy and delight. Catalpa bignonioides is a strong claimant for popular favor wherever a conspicuous, showy tree is needed and is especially good when seen above a mass of lower foliage.

For massing under banks, at the base of high buildings or in front of tall evergreens try the dwarf horse chestnut, Aesculus parviflora, with its long racemes of creamy-white flowers. Equally desirable in this position are the dwarf evergreens. The dwarf mountain pine is an admirable little tree, rarely growing over six feet in height, but frequently spreading over the ground to twice that distance; trailing junipers are also excellent and the yews, especially the American variety, which rarely exceeds five feet with a diameter of twice that measure, and which, in season, is completely covered with its bright red berries are excellent things to plant in front of taller evergreens 
at the base of a barn, or wherever they can be seen to advantage from the house.

Of the flowering shrubs there is, to my mind, nothing else so good as the deutzias. All the varieties of this plant are fine, but for a tall sort I should whesitatingly choose Pride of Rochester and should plant it singly, in groups and as a specimen on the lawn. For a low-growing deutzia I should select Deutzia gracilis and plant it in front of evergreens or taller-growing shrubs so that it might have an effective background for its wealth of lovely white flowers. Then, having planted freely of these two deutzias I should go on and plant all the other varieties of deutzias I could buy, beg or borrow, for I can assure you there is not one which is not well worth cultivating.

Certain of the spiraeas make desirable hedge plants where a light, graceful growth is desired. Spiraea Van Houtte is the best of sorts, and Spiraea Pruni folia fl. pl. equally as good. Where one has an abundant water supply one may plant freely of the various hydrangeas, especially paniculata grandiflora and arborescens, but where it is impossible to water these shrubs sufficiently they are apt to prove a little disappointing. Paniculata makes a dense root growth quite close to the surface of the ground and for this reason is apt to suffer in a dry spell. It is a good plan to mulch heavily with old barnyard manure in the fall, removing the coarsest in the spring and covering the 


\section{MAKING OF A FLOWER GARDEN}

remainder with a few inches of good earth. This protects and nourishes the roots. A heavy mulch of lawn clippings during summer is also helpful, but is quite useless if chickens are allowed access to it as they will scratch it off and, to be effectual, it should be undisturbed. Left alone it forms a felt-like mat through which neither weed can spring nor heat or drought enter.

In somewhat sheltered situations the altheas are very satisfactory and may be used as backgrounds for lower growths, as specimen plants or kept trimmed low as hedges. They are beautiful no matter how they are used but require a little protection in winters in localities of cold, unsettled weather. This may take the form of rough manure about the roots and strips of matting or burlap wound about the top. Often the interposition of a windbreak of some sort will be sufficient.

A number of shrubs of one variety is always far more effective than several plants all different and, where there are a number of separate plantings to be made, it will be well to emphasize some particular variety in each planting, though the entire planting need not be of the one sort, but combined with some other which harmonizes or contrasts well with it or which blooms at a different season.

The planting of shrubs and trees is a simple operation, but there are certain conditions which make for 
success. In the first place the soil should be suitable -well drained, fertile loam, well enriched with well decayed manure. If the soil is poor, gravelly or clay it should be replaced by better ; if the spot is low and wet then resource should be had to underdraining. The planting of trees and shrubs, being a permanent affair, should be done right at the start, for the work cannot be done over every year or two as may be done with annuals and perennials of sorts. The ground should be very thoroughly worked over and then the holes dug for each separate tree and shrub, making the holes deep and wide enough to hold the roots in a natural position at the same depth, or slightly deeper, than they were before transplanting. If their position in woods or nursery is known, then it will be well to place them in the same relative position in their new location-that is, the side of the tree or shrub which faced the north should again be set to face it if possible.

The shrubs should be out of the ground as short a time as possible and as far as practicable be protected from drying out by wrapping with moss and burlap which should not be removed until all is ready for setting the plant in the ground. If the wrappings appear dry, plunge plant and all in a bucket of lukewarm water for a few moments. Two people can handle large shrubs and trees better than one alone. Let one hold the tree erect in the hole while 


\section{MAKING OF A FLOWER GARDEN}

the other replaces the earth about the roots, working it in between the roots so that they do not rest against each other. If any roots are broken they should be trimmed back to sound tissue, using a sharp knife. After the roots are covered with earth, press it down firmly with the feet, pour in sufficient water to nearly fill the hole, allow this to seep away and then fill in the remainder of the earth and make all smooth and fine about the tree. A mulch of litter will be of benefit as it will keep the ground moist and cool.

As a general thing spring planted shrubs do best but it depends largely upon the care they receive during the summer. If neglected and allowed to suffer for water they will not make the vigorous root growth that will enable them to stand the coming winter. More plants are winter killed from summer neglect than from the severity of the weather.

Where the fall is long and mild, good success often follows fall planting. In this case the shrubs should not be moved until they have shed their leaves; then they should be gotten into the ground as soon as possible that they may become established and make some root growth before freezing weather. If a heavy mulch is given considerable growth will be made as the earth is much warmer at this time of year than the atmosphere and the roots can work to advantage. This is not the case in early spring when the earth warms slowly and it is no uncommon thing for plants 
to remain dormant for two or three weeks after planting and if a dry season follows the growth may not be satisfactory unless water is supplied freely.

Another point of importance in planting shrubbery is to buy the stock of reliable florists or nurserymen. It is seldom satisfactory to purchase of one's local dealer unless one can see the plants in bloom and know what he is getting. For this reason all large nurserymen guarantee their stock and are willing to replace any that prove untrue to name or that, given proper care, fail to grow. One's local florists are seldom as liberal in this matter and, although one saves freight or express by purchasing at home, the other disadvantages often more than offset this. On the other hand, most greenhouse plants, especially bedding plants, are much better bought at home as one receives much better value for the money.

The matter of pruning shrubs is one which receives much more attention and causes more anxiety than it should. In my opinion more pruning is done than is necessary. A few shrubs, like the hydrangea, require heavy pruning-about a third of the last year's growth or, in the case of straggly, weak growths, onehalf should be removed in late winter or early spring. This makes for stockier growth and larger panicles of bloom. If a shrub is growing in a stocky, thrifty manner there is little need of pruning other than to keep it symmetrical. What pruning is done should 


\section{MAKING OF A FLOWER GARDEN}

be in the way of removing all weak growth, such limbs as cross and rub each other and sufficient inside pruning to allow the sun and air to penetrate all parts of the plant. Some plants, like certain spiraeas and deutzias, make too dense a growth and it is often a benefit to cut out the centers quite severely, but all pruning of this class of plants should be done in the early summer just after the plants are through blooming, as all spring blooming plants bloom on the old, last season's growth and spring pruning would seriously reduce the amount of bloom. Fall and mid-summer bloomers, on the other hand, should be pruned very early in the spring, as these plants bloom on the new growth. All dead or broken wood should be trimmed from any class of shrubs, trees or roses. In trimming large shrubs and trees all limbs should be cut close to the branch from which they are severed, making a slanting cut parallel to it. Where the limb is of much size the wound should be given a coat of paint or grafting wax to protect it from the weather until the bark has had time to close over it, which it will do in time, if no stub is left.

A good mulch of manure or rough litter in winter will be of benefit to all shrubs and trees and of equal benefit during the dry, hot weather of summer, but it must be remembered that the roots of trees extend outwards to an equal area with the branches and a mulch to be effectual must cover an equal amount of 
space and be protected against the wind and anything which would disturb it. Evergreen branches laid over the mulch in winter form the best possible protection, or a strip of wire poultry netting will be useful. In summer it is simply necessary to keep chickens away from it to preserve it intact.

Economy in the purchase of shrubbery may often be effected by a wise selection of varieties. Any considerable planting runs up into money fast, especially if the larger sized shrubs are selected. Fortunately successful planting depends as much upon a number of plants of one variety as upon the size and distinotion of the sorts. A dozen plants of one variety of spiraea, for instance, is far more effective than one plant each of twelve varieties-try it and see if I am not right.

If, therefore, one has several strips of lawn to embellish with shrubbery and wishes to economize the expenditure as far as possible it will be found a most excellent plan to make a mixed planting on the most urgent section, selecting those shrubs which, by their manner of root formation, offer possibilities of rapid increase and use the products for the subsequent plantings.

. When these new offspring have reached a presentable size they may be retained and the other sorts which can now be spared, removed to another loca- 


\section{MAKING OF A FLOWER GARDEN}

tion, planting out the youngsters in their vacated positions.

There are three classes of plants which lend themselves very readily to propagation through root division, layering and root offshoots. The first is found in those plants which make an exuberant root system of many fine feeding roots and many stems. A good example of this class of plants is found in the Hydrangea arborescens, which may be lifted, pulled apart and the several plants reset without in any way disturbing its growth intention. In this respect it differs materially from Hydrangea paniculata, which, while making a generous root system, has but the one main stem and so is incapable of subdivision. The former, however, is similar in habit to many perennials which are increased by root division-as the shasta daisies, violets, daisies, etc.

Often a plant of $H y d r a n g e a$ arborescens purchased from the florist will admit of the removal of two or three smaller parts without seriously impairing the appearance of the original plant and if these are set out and well cared for they will quickly develop into blossoming plants, for this form is an early and reliable bloomer.

Spiraea Anthony Waterer is another shrub which may be increased by pulling apart the roots; indeed this plant is benefited by occasional treatment of this sort, doing much better and flowering more freely. 
Planted in front of taller shrubs it is a very desirable and reliable plant and if the faded flowers are removed after the spring florescence it will continue to produce flowers throughout the summer.

One of the most easily propagated plants is found in the symphoricarpus or snow berry, indeed, in the case of this pretty shrub the diffeulty is not to increase one's stock, as the new growth is usually prostrate the first year, lying supinely on the ground and, if left undisturbed, will throw out roots at the joints and rapidly produce attractive little plants as robust as the parent stock. Lifting the branches occasionally will prevent this but usually one likes to have the new plants form. I do. After becoming rooted the branch should be severed between the new and the parent plant. As the root growth is dense, consisting of a mass of healthy feeding roots, the young plants can be lifted almost any time and reset without much check to growth. The pale, pinky-white flowers come in mid-summer, followed by the white berries which remain on the bush well into the winter and are very attractive.

Somewhat similar in its manner of increase is the deutzia Pride of Rochester-a magnificent shrub which challenges our admiration when covered with its drooping, bell-shaped flowers in late June and which, under favorable conditions assumes the proportions of a small tree. Like the symphoricarpus, 


\section{MAKING OF A FLOWER GARDEN}

the branches are more or less inclined to a prostrate habit, or, because of their flexibility, are easily pegged down and root easily at the joint, but do not make as vigorous root growth and the joint should have a little earth drawn over it and be pegged down for best results. This shrub is so altogether desirable that half a dozen branches may be devoted to the production of new plants, one or more being produced from each branch. Of those shrubs which throw up suckers from the roots the lilac will occur to most people as a well-known example, so if in buying the newer, double-flowered, named sorts one will insist upon purchasing plants upon their own roots and not be satisfied with grafts, he may soon become possessed of a quite respectable planting of lilacs of notable size and color of bloom. The suckers should be removed as soon as they have had one season's growth for the protection of the parent plant, which will be much depleted in bloom by their presence if allowed to remain permanently.

One of the most beautiful foliaged shrubs, the fernleaved sumac, forms root rhizomes which send up frequent volunteer plants which should be removed and replanted. This is one of the most beautiful ornamentals with which I am acquainted, quite rivaling the Japanese maples. The leaves are compound or pinnate, fifteen to eighteen inches long and of a dark, rich green on the upper surface, the stem a rich 
crimson, an elegant, fern-like spray which is very useful in cut flower work and in autumn turns to the most vivid crimson imaginable. It does best when protected from severe wind, from which it seems to shrink, distorting its symmetrical growth. In good rich soil a half dozen offshoots may appear the next year after planting, and once one has become familiar with its beauty all will be welcome.

Another shrub or small tree with similar characteristics is the Aralia spinosa or Hercules' club, as it is commonly called. This also has the compound leaves, somewhat resembling the black walnut, but of gigantic proportions, between two and three feet in length and quite as broad, giving the tree a most tropical effect. It is very easily transplanted and a few trees in a clump are exceedingly effective. Where only a single shrub is wanted it is not at all difficult to hold it in check by hoeing out the shoots as they appear.

The euonymus, or burning-bush, as it was known to the Indians, propagates itself by the means of its coral berries, which appear in quantities in late summer and fall and remain on the bush until winter. One finds the volunteer plants appearing every spring in places where one least expects them and can lift and transplant them wherever desired. One which for years has been a resident of my garden has a pedigree dating back to early colonial days when its an- 


\section{$1 \%$ MAKING OF A FLOWER GARDEN}

cestor grew in the dooryard in the old homestead at Valley Forge. A grandmother journeying, a young wife, into what was then the wilderness of central New York, brought with her to her new home a slip of the burning bush, to keep alive, in the new home, some familiar reminder of the old. In later years a daughter, still following the lure of the trail as it looked toward the setting sun, carried a younger scion $t r$ the far plains and woods of northern Indiana and when my own mother, still following the westering trail, made a new home for herself and little ones in Michigan, an offshoot from the bush in Indiana was donated, and grows and bears its chocolate colored flowers and ruddy berries as freely as in the limestone soil of Chester County, Pennsylvania.

Another most attractive shrub which may be easily raised from spring sown seed is the Buddleia, a plant with long racemes-in the newer forms over twenty inches long-of violet mauve flowers of a delightful violet fragrance. Spring sown seed will often produce flowering plants the first season and the second will attain a height of three to five feet and be a perfect bouquet of bloom throughout the summer. The branches are somewhat pendulous and in the young state are the better for a little support. They afford delightful material for cut flower work and the odor has that fugitive, elusive quality of the violet, 
seeming to come from different directions at times and to elude one's search.

It will be found a most excellent plant to use in connection with the Spiraea Van Houtte, as it comes into bloom after that splendid plant has rested on its laurels for the summer and keeps the hedge row alive with bloom and fragrance.

\section{LIST OF SHRUBS AND TREES}

\section{NAME \\ SEASON \\ HEIGHT \\ COLOR \\ LOCA- \\ Small shrub White, rose \\ $\mathbf{X} \mathbf{Y}$}

Abelia grandiflora.... Summer

Esculus Hippocastanum

fl. pl............. June

Amorphs Montana... . June

Aralis spinosa.. . . . . .... Aug.

Aralea amosna........May

Azales mollis. . .......... May

Barberry aquifolium... May

Barberry thumbergii. . . May-June

Barberry vulgaris. .....May-June

Buddleia Variabilis

Veitchiana ........July-frost

Calyeanthus Floridue. . May-June

Caragana (Chamlagu)...April-May

Caryopteris Magtacanthus.............. Summer-autumn

Catalpa bignonioides... June

Cephalanthus occidentalis.............Mid-summer

Cerasus Hitortensis fi. pl. April

Cercis Canadensis..... April

Chimonan thus fragtani. April

Chionanthus virginies. . June

Cladrastus lutea....... June

Clethra alnifolia.........Junly-Aug.

Cornus Florida, rubra. . May-June

Cratsegus monogyna

alba plens..........May-June

Cratigus monogyna

pand..............May-June

Cydonia Japonica...... May-June

Cytisus Laburnum. .... June

Daphne Cneorum...... May

Desmodium penduli-

florum ............ Sept.

Dimorphanthus man-

churicss, aures....... All summer

Tree
$4^{\prime}-6^{\prime}$
$10^{\prime}-15^{\prime}$
$2^{\prime}$
$2^{\prime}$

$10^{\prime}-12^{\prime}$

$8^{\prime}-10^{\prime}$

$8^{\prime}-10^{\prime}$

$6^{\prime}$

$4^{\prime}-6^{\prime}$

$3^{\prime}-4^{\prime}$

$3^{\prime}-4^{\prime}$

$20^{\prime}-30^{\prime}$

$4^{\prime}-6^{\prime}$

Tree

Tree

$6^{\prime}-8^{\prime}$

$6^{\prime}-8^{\prime}$

Tree

$3^{\prime}-5^{\prime}$

$8-10^{\prime}$

$10^{\prime}-12^{\prime}$

$10^{\prime}-12^{\prime}$

$10,-12$
$6^{\prime}-8^{\prime}$

6"-8"

$3^{\prime}-4^{\prime}$

Tree

* X indicates full sun; $Y$, partial shsde;

locations combining sun and ahado.

$$
\begin{array}{ll}
\text { White } & \mathbf{X} \mathbf{Y} \\
\begin{array}{l}
\text { Violet, purple } \\
\text { White }
\end{array} & \frac{\mathbf{X}}{\mathbf{X}} \mathbf{Y} \\
\begin{array}{c}
\text { Crimson } \\
\text { Yellow, orange, } \\
\text { flame }
\end{array} & \mathbf{Y} \\
\begin{array}{c}
\text { Yellow flowers, } \\
\text { scarlet berries }
\end{array} & \mathbf{X} \mathbf{Y} \\
\text { Violet } & \mathbf{X} \mathbf{Y} \\
\text { Violet, mauve } & \mathbf{X} \mathbf{Y} \\
\begin{array}{l}
\text { Purplioh brown } \\
\text { Yellow }
\end{array} & \mathbf{Y}
\end{array}
$$

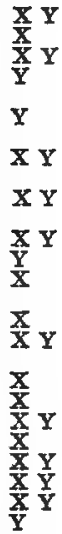

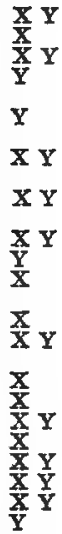

Lavender, blue

White, spotted

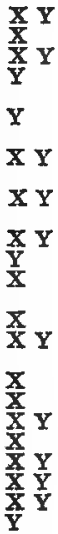

Cresmy white

Pink, white

Crimeon

Yellow

White

White

Creamy white

White, pink

White

$\mathbf{x}$

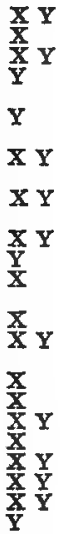

X.

Bright scarlet

Scarlet

Yellow

Pink

Rose, white

Variegated leaved $\mathbf{X} \mathbf{Y}$
$\mathrm{X}$

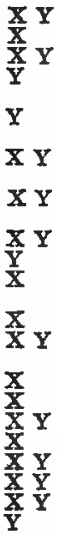

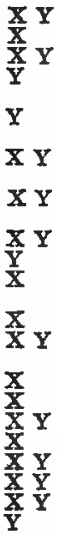

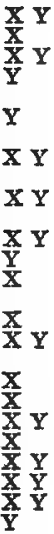

$\mathbf{X}$
$\frac{\mathbf{X}}{\mathbf{X}} \mathbf{Y}$
$\mathbf{X} \mathbf{Y}$
$\mathbf{X} \mathbf{Y}$
$\mathbf{X} \mathbf{Y}$

$\mathbf{X}$
$\frac{X}{X} \mathbf{Y}$
$\mathbf{X} Y$
$X Y$
$X Y$
$X Y Z$

$Z$, full shade; $X Y$ and $X Y Z$, 


\section{MAKING OF A FLOWER GARDEN}

\section{LIST OF SHRUBS AND TREES (Continued)}

\section{NAME}

Dimorphanthus argen-

tea ................ summer

Deutzia, Pride of Rochester...............June

Deutzis crengta fi. pl. . . June

Deutria candidissima ... June

Deutris gracillis....... June

Diervilla florlbunda... . May-June

Diervilla candida. . . . . May-June

Elragnus longipes. . . . Summer

Fagus sylvatica purpurea.............All summer

Forsythia Fortunci. . . A April

Halesia tetraptera. . . . May

Hydrangea randiflora panieulata...........Aug.-Sept.

Hydranges arborescens.June

Kalmia, latifolia, augustifolis............. May-June

Lonicera Tartarica, alba, rosea............ June-Aug.

Laburnum Cytisus. . . May-June

Magnolia Kobus...... May

Magnolia purpurea.....All summer

Philadelphus coronarius f. pl..............June

Philadelphus purpureamasculata ........... June

Pyrus Japonica. . . . . . May

Potentilla fruticosa. . . July-iall

Rhodotypes kerrioides.. May

Rhus Cotinus.......... Mid-summer

Rhus glabra laciniata... All summer

Rhus typhins.........All summer

Sambucus nigra...... . All summer Symphoricarpus racemosus... . . . . . . . . July-Aug.

Spiraa Van Houtte... . May

Spira Thunbergil..... May

Spiraa, Anthony

Waterer............All summer

Syringa, Mme. Casimir Perier.............May

Syringa, President Grevy.............May

Syringa, Souvenir de Louis Spatlue. . ..... May

Byringa, Virginite..... May

Tamarix Africana. . . . May

Tamarix Indica. .........Aug.-Sept.

Tamarix estivalis..... July

Vitex Agnus-castus. . . Late summer

Viburnum plicatum... . June

Viburnum Lantana. . . Mas-Juno

Viburnum Carlesi.....

Xanthoceras sorbifolia. May

\section{LOCA- \\ TION*}

Tree Variegated leaved X Y

$6^{\prime}-8^{\prime} \quad$ White

$6^{\prime}-8^{\prime}$ Pink

6'- 8' White

2 White

6'- 8' Crimson

$\begin{array}{lll}6^{\prime}-\mathbf{8}^{\prime} & \text { White } & \mathbf{X} Y \\ 6^{\prime}-\mathbf{8}^{\prime} & \text { Orange fruit } & \mathbf{X} \mathbf{Y}\end{array}$

\begin{tabular}{|c|c|}
\hline $\begin{array}{l}\text { Tree } \\
8^{\prime}-10^{\prime} \\
\text { Trees }\end{array}$ & $\begin{array}{l}\text { Purple } \\
\text { Yellow } \\
\text { White }\end{array}$ \\
\hline $\begin{array}{l}4^{\prime}-5^{\prime} \\
5^{\prime}-6^{\prime}\end{array}$ & $\begin{array}{l}\text { White } \\
\text { White }\end{array}$ \\
\hline $4^{\prime}-8^{\prime}$ & White, rose \\
\hline $\begin{array}{l}6^{\prime} \\
\text { Tree } \\
\text { Tree } \\
10^{\prime}-12^{\prime}\end{array}$ & $\begin{array}{l}\text { White, rose } \\
\text { Yellow } \\
\text { White } \\
\text { Purple }\end{array}$ \\
\hline
\end{tabular}

10'-12' Whito

X Y Z

10'-12' White, spotted purple

4'-6' Searlet

21/2, Yellow

$4^{\prime}-5^{\prime} \quad$ White

8' - 9' Purple

$4^{\prime} \quad$ Crimson fruit

4' Brilliant fall

\section{foliage}

6'-10' Golden

3'-4' Pink

5'- 6' White

$3^{\prime}-4^{\prime} \quad$ White

$\mathbf{X} \mathbf{Y}$

$\bar{x}$

$\vec{X}$

$\mathbf{X} \mathbf{Y}$

$\mathbf{X} \mathbf{Y}$

$\mathbf{X} \mathbf{Y}$

I

$\mathbf{Y}$

$\frac{x}{x}$

$x$

11/2'-2' Crimson X Y

$6^{\prime}-8^{\prime}$ White $\mathbf{X} \mathbf{Y}$

6'- 8' Blue X Y

6'- 8' Reddish-purple

4h Blush pink

8'-10' Pink

8'-10' Pink

8'-10' Pink

$6^{\prime}-8^{\prime} \quad$ Lila

6'- 8' White

$9^{\prime}-12^{\prime}$, White

Dwarf i White

Tree White
$X Y Z$

$X Y$

$X \mathbf{Y}$

$\mathbf{X} \mathbf{Y}$

$\mathbf{X} Y$

X Y

$Z$

$\mathbf{X} \mathbf{Y}$

$X \frac{Y}{X}$
$\frac{Y}{X}$
$\frac{X}{X}$
$\frac{Y}{Y}$
$\frac{Y}{X}$
$\frac{X}{Y}$
$\frac{X}{Y} Y$
$\frac{X}{X}$ 


\section{CHAPTER XVI}

\section{THE HARDY LIIY BED}

From the middle of August until the ground freezes one may plant bulbs of hardy lilies with certainty of successful florescence and growth the following spring, but if the planting is deferred until spring, nothing but disaster may be looked for. I know that many catalogues offer bulbs of hardy lilies and recommend their planting in the spring, but the bulbs so offered are those which remained unsold in the fall and this method is taken to reduce the loss as much as possible. Lily bulbs, to do well after transplanting, should remain out of the ground the shortest possible length of time and bulbs that have been out of the ground from August, September or even October until spring are practically worthless.

The well-known hardy garden lily candidum, or lily of the Annunciation, is one of the first to ripen its bulbs as it is the first to bloom. In August it completes its period of growth and takes a brief rest before throwing out the crown of leaves which remain green throughout the winter; this is the season 


\section{MAKNNG OF A FLOWER GARDEN}

at which the bulbs should be lifted and reset. They do not feel the change then and have time to make this fall growth in the new situation.

In planting the candidum lilies the bulb should be placed but an inch or two below the surface, as this lily differs materially in this respect from other lilies, which, with hardly an exception, require deep planting. - Like all lilies, a situation which affords protection from hot sun in summer and still affords sufficient sunshine, is necessary for best results; for this reason lilies do best when planted among the shrubbery or the plants of the hardy border. A mulch of lawn clippings during the hot, dry weather of summer, drawn well up about the stems of the plant, is beneficial. Anything which prevents the earth becoming hot and baked will make for the wellfare of the bulb.

The most important lily after the candidum, and far excelling it in beauty, is the stately auratum. This is, of all lilies, the finest and most satisfactory. It should be planted by the dozen and if the length of the purse permits, by the hundred. Plant in well drained soil, for water about the bulbs is fatal to all lilies, and set the bulbs nine inches deep in thoroughly dug and worked soil, well enriched with old, well-decayed manure, but be careful that none of this comes in contact with the bulb. A considerable hole should be made in the mellow soil to the required 
depth and a handful of clean, sharp sand placed in the bottom; on this place a little pad of sphagnum moss and on this set the bulb and pack about it sufficient sand to cover it and fill in the hole with earth and place a stick or stone to mark the location of each bulb. A good sized stone placed at one side of each point, so that the lilies may come up on the same side of each stone is a safeguard when clearing off the bed in the spring and is less apt to be destroyed than a small stake.

Where the drainage is not naturally good it will be time well spent to excavate the bed to a depth of two or more feet and fill in several inches of broken stone and gravel, discarding the subsoil, if undesirable, especially if it contains clay or hardpan and using the surface soil in its place and adding a good garden loam, leaf mold and some sharp sand to the surface layer. Worms and ants-two chief enemies of lilies -are much less apt to exist in well drained soil than in damp or unwholesome earth.

For low beds of solid color or for borders on beds of taller lilies the little Siberian lily, tenuifolium, is exceedingly interesting and satisfactory. It grows only about a foot high and its dainty, recurved blossoms are of the most dazzling vermilion scarlet imaginable. It is one of the first to bloom and is perfectly hardy. The bulbs are small and should not be planted quite so deep as the larger varieties. 


\section{MAKING OF A FLOWER GARDEN}

Exceedingly popular and of the easiest culture, the Speciosum lilies are found in nearly all gardens where lilies are known and loved. They differ materially in manner of growth, being less erect than the candidums and auratums, and branching quite freely. The flowers, which are sharply recurved, show the pure white, green veined flower of Speciosum album, the white, splashed and spotted with crimson of Speciosum roseum and the deeper colored crimson and rose of the Speciosum melpomene. The Speciosums are a more persistent lily than almost any other fine variety and should be planted in permanent quarters and not disturbed as long as they are doing well. Should trouble appear, however, the bulbs should be lifted during their period of rest and examined; usually it will be found that worms or ants have made nests in the bulbs, or decay has attacked them. In either case the bulbs should be thoroughly cleaned and all injured or decayed scales removed (usually these may be utilized to start new bulbs, as, if planted in clean sand, each scale will produce, at its base, a tiny bulblet which in two or three years will develop into a blossoming bulb) and the bulb reset in a new place in perfectly clean soil and with sharp sand about it.

It is a question if any lily other than white will rival our affection for the old candidum, but there are several white lilies and white, tinted with other 
shades which are very desirable. Longiflorum multiflorum, so popular as an Easter lily, sueceeds admirably in the open ground. Lilium Philippense, a new lily from the Philippines, as its name indicates, comes very highly recommended and much resembles the Harrisi, but the flowers are rather more slender and much longer-nearly nine inches-the diameter of the flower being some six or seven inches, so it will be seen that it is something of a flower. The growth, however, is not as stately as that of the candidum or auratum, being only about two feet high. Browni is a beautiful lily, tall and stately, with trumpet shaped flowers of a creamy white inside and purple outside, while the beautiful Parryi-another trumpet-shaped flower-has long, wax-like chalices of golden yellow, a color almost as desirable as white. Washingtonianum gigantium-a variety often reaching the imposing height of six or eight feet, and Hansoni, a beautiful yellow, dotted with purple, are other of the rarer sorts, while any number of orange red and spotted lilies are to be had, some of them quite desirable, but should be selected from the blossoming plant rather than from the catalogues, to avoid disappointment.

Protect the lily bed in fall, after the ground has frozen lightly, with a few inches of rough litter held in place with brush and do not remove until severe freezing weather has passed in the spring and then 


\section{MAKING OF A FLOWER GARDEN}

only remove the coarsest, leaving sufficient to protect the young shoots, in case of a late frost, for lily shoots are very tender when first they appear above ground and I have seen a whole bed of four or five inch shoots literally cooked by a late frost, and while that does not always kill the bulb it does do away with any chance of bloom for that season. 


\section{CHAPTER XVII}

BULBS FOR FALL PLANTING

I woutd like to urge every owner of a garden or a bit of permanent lawn, to make a special effort this fall towards the liberal planting of spring-blooming bulbs, for, believe me, they are the most valuable asset of the garden. Hardy shrubs and perennials are equally important in point of possession but do not yield the immediate return that one realizes from hardy bulbs. All of the bulbs which the florists offer for fall planting are specially prepared in Holland and in Japan for the trade and each bulb holds, folded in its enveloping sheath of scales or tissue, the embryo flower bud, which only requires the fostering care of nature to spring into insistent life and beauty at the awakening of spring.

Crocus, hyacinth, tulips, scillas, anemones and all the fair cortege of swaying, fragrant blossoms are as certain to repay the trifling cost and trouble of their planting as weeds are to spring up, or grass to grow where it is not wanted. Shrubs give little, if any, return the first year and many of them re- 


\section{MAKING OF A FLOWER GARDEN}

quire several years to come into sufficient size and beauty to be notable, but bulbs are at their best from the start and require little attention for several years after planting; many of them, especially the narcissus, jonquils, daffodils, and hardy lilies, requiring to be left entirely alone until a crowded condition makes it necessary to lift and divide the clumps and reset in fresh soil.

Crocus are at their best when planted in the grass of the lawn, about trees, and in situations where it will not be necessary to run the lawn mower at too early a day, as they require time to mature their leaves before being cut, otherwise there will be no lovely chalices of white, of gold or of blue the following spring. In planting it is only necessary to lift a bit of sod and thrust the corm down an inch or more into the soil, pressing back the sod above it, and that is all. Buy the large, mammoth, manyflowered sorts which give a dozen or more blooms to a bulb and plant them singly and in groups in as careless, natural a way as possible.

Crocus may also be used to border beds of perennials or to fill in beds of larger bulbs such as tulips, hyacinths or lilies and are especially effective with scillas.

The tulip and the hyacinth are, probably, first in the affection of the flower loving gardener. Certainly they are, of all spring-flowering bulbs, the most showy. 
Tulips have the advantage of being easily raised and so moderate in price that all may afford to plant liberally of them and it is always an economy, when planting this bulb to purchase by the hundred rather than by the dozen. If one is not desirous of geometrical designs it will be found cheaper to buy the mixed bulbs, but where beds of uniform color and height are desired one should study the catalogues and select those of uniform height and equal season of bloom. I like to grow tulips as a border to beds of hardy perennials or shrubbery, planting the bulbs about a foot apart and four inches deep. This allows the bulbs to make a natural increase into effective clumps. In planting in solid beds or as a border where the bulbs are to be lifted after ripening and replanted in the fall, they should be set but five inches apart.

Hyacinths, which require practically the same treatment, should be planted at least seven inches apart and four deep. Like all bulbs they require rich, well drained soil but no manure should be allowed to come in contact with the bulbs and only old, well decayed manure should be incorporated in the soil of the bed.

Narcissus, the most beautiful and satisfactory of all spring bulbs, should be planted in long rows for best effect and in a position where they can remain undisturbed for several years. I like a position on 


\section{MAKING OF A FLOWER GARDEN}

the east side of a shrubbery border or hedge best, as the ground is then protected from the sun during the hottest weather, when the bulbs are ripening and preparing for another season's bloom, while the deciduous nature of the shrubs allows an abundance of sunshine early in the spring when the bulbs are in bloom. Plant narcissus four inches deep and twelve inches apart. This allows for the increase of the bulbs, which form in a circle around the original bulb and the clumps should not be disturbed until they have completely closed up the space between them, and not even then until they begin to show, by a falling off in bloom, that this is necessary; then the bulbs should be lifted and divided and reset in fresh soil. It is always well to set in triple rows, as the effect is better from the start, and, if only the largest bulbs are used for the new plantingthe smaller being planted in some less conspicuous place to develop-the effect will be good from the start. Narcissus, daffodils and jonquils all require the same treatment.

In selecting narcissus one should choose freely of the big, trumpet varieties, such as Horsfeldii, Emperor, Empress, Sir Watkins, Mrs. Langtry and the like; these mammoth blooms are not only very beautiful and conspicuous, but have the additional merit of remaining in bloom a surprising length of time. The old-fashioned Von Sion should find a place in 
every garden and the Poet's Narcissus should be one of the most conspicuous; this and the Pheasant's Eye are exceedingly fragrant and a very satisfactory cut flower.

There are many other spring-blooming bulbs of lesser importance and less certainty of culture which are useful for filling in odd corners, but none is of the importance of these few already mentioned and many of them fail entirely in the hands of the amateur. In sections where the snow remains on the ground all winter, snowdrops may be cultivated with success and are one of the most welcome harbingers of spring, but are unreliable in sections where the winter is broken with sudden changes of temperature. Where it is practicable to grow them they should be planted two inches deep and three inches apart in well-drained soil. Blooming at about the same time, the Lebanon Flower, Puschkinia libanotica, is effective for planting back of lower-growing bulbs or for naturalizing among shrubbery where it may remain undisturbed for three or four years. This has large spikes of white flowers delicately striped with blue and resembles somewhat the single hyacinth. Ornithogalums are striking plants with tall spikes of white flowers with jet-black centers and an agreeable perfume and should be grown in clumps of a half-dozen or more in the hardy border, or interspersed among shrubbery. 


\section{MAKING OF A FLOWER GARDEN}

Although entirely hardy, bulbs do better if given a covering of rough manure or litter in the fall. This not only protects but prevents the heaving of the ground under the action of frost, a process which often tears the tender roots away from the bulb or, if planted too shallow, throws it out of the ground, either process proving fatal.

PLANTING TABLE FOR BULBS

Distance

\begin{tabular}{|c|c|c|c|}
\hline Name & $\begin{array}{l}\text { Depth } \\
\text { inches }\end{array}$ & $\begin{array}{l}\text { apart } \\
\text { inches }\end{array}$ & $\begin{array}{l}\text { Planting } \\
\text { season }\end{array}$ \\
\hline Anemone...$\ldots \ldots$ & . 1 & 6 & Spring \\
\hline Crocus ............ & 2 & $21 / 2$ & Fall \\
\hline Colchicums ........ & 3 & 3 & Fall \\
\hline Hyacinths ......... & 4 & 7 & Fall \\
\hline Jonquils .......... & 3 & 6 & Fall \\
\hline Narcissus $\ldots . . . \ldots$ & 4 & 12 & Fall \\
\hline Scillas ........... & 3 & 3 & Fall \\
\hline Snowdrops ........ & 2 & 3 & Fall \\
\hline Tulips .......... & 4 & 5 & Fall \\
\hline Ixias $\ldots . . . . . .$. & 2 & 3 & Fall \\
\hline Winter aconite .... & 2 & 3 & Fall \\
\hline
\end{tabular}




\section{CHAPTER XVIII}

FALL WORK IN THE GARDEN

FALL work in the garden should really commence about the fifteenth of August, at which time one should begin to make sowings of hardy perennials for the next year's garden. I always try to get my pansy seed into the ground by the middle of the month if possible and to lift and move my Annunciation lilies at that time. They are then dormant and the disturbance does them no harm, though even a week later it will, as they will have again begun preparation for the next season's period of bloom.

This, too, is the season for lifting and resetting all of the narcissus family. Wistarias can be trimmed this month with advantage also.

Where one has the convenience of a coldframe or a spent hotbed the conditions for sowing seeds of hardy perennials are all that could be desired, but where these are not at hand or the hotbed has been utilized for summer plants, like crinums or amaryllis, then one must improvise a plant bed in some outof-the-way corner. Any bit of good, friable soil will 


\section{MAKING OF A FLOWER GARDEN}

answer. It should be made fine and mellow and should, by preference, be surrounded with a board frame. This need be but a few inches high and may be just four boards beld together with stakes, or the boards may be nailed together at the corners and the frame set over the ground after the seeds are planted.

If there is any probability of the ground being disturbed by chickens, cats or dogs, it will be best to nail lath across the top of the boards, placing them the width of the lath apart. This is a good plan any way, as it affords a shade for tender little seedlings.

Seeds of many hardy perennials may be sown in the fall, making a distinct gain in time and also lessening the amount of work to be done in the spring, when there is always more to do than one can find time for.

Among the seeds which it best pays to sow are the antirrhinum, digitalis, delphinium, poppies-especially perennial varieties-nicotianas, primrose, or cowslips, lychnis, sweet alyssum, golden saxatile, hibiscus and the like.

Such fine seed as poppies do not need to be covered; merely scatter as thinly as possible over the soil. As poppy seed always comes up much too thick no matter how thinly one trys to sow it, it is a good plan to mix a packet of the seed with a teacup full of dry sand and scatter this as thinly and evenly as possible. 
Larger seed, like that of the pansy, can be sown in shallow drills, pressing the ridges of soil back upon it and pressing all down firmly with a piece of smooth board. This pressing down of the soil is very important and insures the tiny seed against drying out, as might occur, did it lie in ever so small a hole between two grains of earth. Press all these particles of earth together and the little seed is safe.

Plant each variety of seed in a section by itself, as was done with the spring sown seeds in the hotbed, separating them with strips of wood and labeling each with name and date of sowing. Water the bed thoroughly, but with a very fine-rosed watering pot, unless the soil is quite moist, when only a light watering will be needed. Cover for the first few days with a newspaper, or until the seedlings appear. Then remove so that they may have all the sun and air possible.

If, later in the season, before severe cold weather, there should be an empty coldframe or hotbed available, the more tender sorts of plants may be transplanted into it, setting the little plants an inch or more apart each way, according to the amount of room. Pansy plants will come up and make considerable growth before cold weather and it is a distinct advantage to transplant into a coldframe and winter under glass. Handled in this way they should be showing buds when ready to transplant into the 


\section{MAKING OF A FLOWER GARDEN}

open ground in April and be in bloom by the first of May.

The plants which are left in the open beds should be protected at the approach of cold weather by having sash, boards or canvas placed over the bedsanything which will shed water-and being lightly banked with leaves. Evergreen boughs, when available, make the very best of covering.

In growing the hardy grasses it is quite important that they should be started in spring and wintered over in a coldframe and set into permanent places in the following spring. Treated in this way, one will soon come into possession of a valuable stock of these stately plants at a very nominal cost.

Most hardy perennials and shrubs which bloom in the spring may be moved in the fall with marked benefit, providing the work is done early enough to allow the roots to become established before cold weather. Deciduous shrubs should not be lifted before the leaves have fallen or begun to fall, but after that time the work should progress as rapidly as possible. Spring blooming plants which have an evergreen crown of leaves may be lifted any time after they have completed their season's growth, but such plants as the Japanese anemone should not be disturbed at this season. These and the chrysanthemums, golden glow, tritomas and other late bloomers are better divided and moved in the spring. 


\section{FALL WORK IN THE GARDEN 189}

As soon as the first frost has killed the summer annuals the beds should be gone over and all dead growth removed and the beds raked over and put in shape for spring work. It is an excellent plan, when the beds are to remain empty until late spring, to sow some sort of a cover crop-crimson clover, rye or the like-and turn this under in the spring sufficiently early for it to decay before putting in the new crop of annuals or other flowers. This replaces the constantly decreasing supply of humus, as well as protects the ground from leaching during winter-another source of wasted fertility.

If one has found a certain planting unsuccessful, either from an unfavorable location or from a poor arrangement of form and color, one can, at this time, rectify the error by changing the arrangement. One of the most interesting features of gardening is this studying out of the question of form and color harmony. It is not always possible to strike just the right note in the planting of unfamiliar things, but it is always possible to learn from experience and to profit by one's failures. If one has found a planting unharmonious and is at a loss as to just what new combination to try, one can quite easily solve the problem by gathering the flowers of the plant in question and carrying them around the garden, placing them by the side of different plants until one is found which harmonizes with it. If the plant is a 


\section{MAKING OF A FLOWER GARDEN}

large, free-flowered one so that large sprays can be taken, these may be stuck in the ground and one can retire to a distance and note the effect. Flowers which combine well in a bouquet will always combine well in a garden.

One of the combinations I have always found successful is scarlet and white. Nicotiana affinis and salvias always are fine together; so also are scarlet lychnis and white clematis. There is a soft, rosecolored lychnis which, when it can be induced to bloom sufficiently early, as in warm, protected borders, is lovely with the white of Deutzia gracilis. Indeed, white is a perfectly safe combination for mixing with any other color. Mast shades of mauve will harmonize with yellow and with many shades of rose and scarlet, but do not go well with reds or magentas.

At this time of the year one should repair all garden construction, as of fences, trellises, pergolas, seats, gates, paths and the like. An already weakened part is quite apt to succumb under a winter storm or avalanche of snow or sleet. Then, too, it is a distinct advantage to have all this part of the work out of the way before the busy days of spring, when there is always so much more to do than there is time for. The fall is, of all times, the best for getting rid of weeds, as at this time all such growths may be pulled up and burned, preferably on the spot in which they grew, and thus the seedling of 


\section{FALL WORK IN THE GARDEN 191}

another crop be prevented. If carried any distance there is danger of scattering the seeds, and those already shed beneath the plant are not destroyed but are left to germinate and make trouble another year. If all seed pods are kept off of perennial plants the care of the garden will be much simplified, as seedling plants are just as much trouble to eradicate as any other form of weed growth. Phlox, especially, should not be allowed to self-sow, as it is sure to prove a nuisance, especially when it gains a foothold in the pæony beds, as it will come up in the clumps and it is impossible to dislodge it without injury to the pæonies. Frequently it becomes necessary to lift the plants and disentangle the roots from the phlox. 


\section{CHAPTER XIX}

\section{WINTER PROTECTION}

THE whole subject of winter protection resolves itself into an intelligent understanding of what one should protect from, the various conditions of the winter weather and the habits and constitutions of the things to be protected. People living in regions of perpetual winter snow, where the fall comes early and remains on the ground until well into the spring months have the question practically settled for them offhand; it is merely necessary to leave things to Mother Nature who will take excellent care of them. There is no covering which man can devise which will equal in efficiency the blanket of cold, white snow, as it protects equally from cold, sudden changes to a higher temperature and sunshine, which odd as it may seem, is really worse for a plant at the winter season of its existence than severe cold, for this reason-the sunshine stirs the plant to life, drawing the sap up into twigs and branches, then the cold swoops down, freezing the imprisoned sap and expanding it beyond the capacity of the plant's cells, 
which, unable to stand the strain, are ruptured and the plant destroyed.

Any protection which ignores this condition must prove ineffective. The most perfect covering is one which preserves the most even temperature, and for this reason it is best to defer placing any kind of covering over plants, trees or shrubs till they have completed their season of growth and shed their leaves and become practically dormant. If, in addition to this, the ground is already frozen so that the protection may hold the frost in the ground, so much the better. To keep the majority of plants in cold storage from the time they are laid down in the fall until they are awakened in the spring should be the aim with all but the most tender of plants. Tender roses and water lilies, on the other hand, are benefited by a covering which keeps out frost, though not excluding air, for plants need air even during their long winter's sleep. For this reason it is always well, in protecting such plants as do not die down to the ground in fall, to give the necessary amount of covering and then protect the covering itself by boards or something which will shed water, always remembering to allow room for the circulation of air. In covering single plants of low growth it is generally convenient to pile leaves lightly about it and then turn a box over the whole. This not only keeps out wet but retains the leaves in place, but in 


\section{MAKING OF A FLOWER GARDEN}

doing this it will be well to knock out both ends of the box and set it with the closed side against the weather, then if the leaves do become wet they will quickly dry out and not remain a wet, moldy mass about the crown of the plant.

But dryness about the crown of a plant is impossible if a poorly drained soil permits water to settle about the roots in winter. There are many plants which are not injured, but rather benefited, by a wet soil in summer, but only marsh and aquatic plants enjoy a damp bed in winter, so where there is not sufficiently good drainage to insure the prompt shedding of water the bed should be raised suffciently, by the addition of more soil or by cutting down the surrounding soil or the digging of a drainage channel about and away from the plant, following the slope of the land, to insure against trouble.

Some plants are not injured by the presence of ice about the roots in winter, while others are very, sensitive. I have a beautiful variegated woodbine or vitis on the north side of the house where the ice banks up over the roots every winter, but it comes out flourishing in the spring, though not afforded the slightest protection throughout our long, severe northern winters; the drainage, however, is perfect.

I think it always is better to leave a plant unprotected, as to its top, if it is hardy enough to endure 
this treatment, but few plants are injured by a good mulch of rough barn-yard litter about the roots, which not only protects but feeds.

Where a plant is protected beyond its actual needs a tender growth is likely to be favored in the late days of winter or early spring, which the cold, usually following on unseasonable weather, injures. Anyway, this tender growth is seldom as desirable as the hardier more rugged putting forth of the unprotected plant and the greatest difficulties I have met with in wintering plants has come from injudicious protection-protection which seemed demanded but proved enervating to the plant.

Plants which die down to the ground in winter usually have sufficient top growth, if broken down about the plant, to give all the protection needed. Plants which do not die down, but make a winter crown of leaves, like the hollyhocks, Canterbury bells, and pansies, are often a problem, as they require a considerable amount of air during winter. Evergreen boughs provide the very best covering, as they shut out wind and sun and admit air. Where plants are grown in long rows I have had good results by driving a few notched stakes into the ground between the rows lengthwise of the beds, placing poles on these and hanging evergreen boughs over the poles, the ends trailing on the ground. This is an excellent arrangement for roses, azaleas, rhododendrons 


\section{MAKING OF A FLOWER GARDEN}

and the like, also for pansies, foxgloves and flowers of that sort. In places where the beds are not too much in evidence, and evergreen boughs not available, corn fodder may be used and the sweet-corn patch may have its usefulness extended by furnishing a warm covering for the taller plants in need of shelter.

In protecting tender roses, azaleas and rhododendrons, however, I have found it profitable to further protect the roots by placing pieces of sod about them, bringing it well up about the stems and fastening it there with stout cord. Most of the injury to tea roses occurs near the ground where the frost heaves the earth away from the stem, admitting the cold, and it is no unusual thing to find the stems ruptured at this point. This the sod effectually prevents. Small plants may be quite covered in this way and will come through the winter in fine shape.

Vines of a tender nature, especially clematis, should be laid down if practicable and covered with dry leaves and boards. Hardy vines, especially those which cling naturally to walls, as the trumpet vine, Boston ivy and the like, should not be disturbed. The Boston ivy is somewhat tender and may be protected during its first winter or two by tacking burlap, matting or old carpet over it, first securing the ends of the burlap, etc., to strips of wood and securing these in turn to the wall or trellis on which the 
vine is growing. It is a good plan, in putting up trellises or netting for vines, to have their winter protection in mind and arrange them so that they can be released with little trouble. Wire netting which is stapled firmly to a wall cannot be easily removed. Better staple it to a stout piece of wood which in turn may be attached to the house by hooks at the top, and to stout stakes driven into the ground at the base.

Bulbs and hardy lilies need little protection other than a mulch of rough barn-yard manure. All trees and shrubs are improved by the same treatment. In the vegletable garden the tender globe artiehokes should have the large leaves cut back and the crowns of the plants covered with coal ashes. The cold frames should be provided with water-proof coverings and mats for the more severe months of the winter. It is seldom that anything is needed inside the frames.

The lily pools should have the water drained off, the pool filled with leaves and a cover of boards or canvas put over all. The cover should extend a couple of feet on all sides of the pool and the leaves be stuffed tightly between the edges and the pool, as quite as much damage results to the walls of the pool from the heaving of the ground under frost as from frost inside the pool.

If one is the fortunate possessor of a few discarded 


\section{MAKING OF A FLOWER GARDEN}

doors they may be made useful in affording a snug corner to some tender shrub too large to burlap. The door should be placed at an angle to shut off the sun and the prevailing wind and firmly braced in position or it may cause far more damage than it prevents.

Care of house plants during winter depends so largely upon the conditions under which they are to be grown that only general hints will be really practical. When there is a conservatory, where the plants can, at will, be shut away from the atmosphere of the living room and given a semi-greenhouse condition, the matter resolves itself into a simple matter of heat, moisture and proper ventilation; but where one must depend upon a bay window, which is really a part of the living room, or even just the ordinary living room windows, then the matter becomes more complicated and the wise flower lover will content herself or himself with growing those plants least exacting in their requirements.

It is possible, however, so to arrange a bay window of fair proportions that it becomes, in effect, a miniature conservatory or greenhouse, and this without an unreasonable outlay. The important point here is a watertight floor which may be separated from the living room floor, either by sinking it somewhat below the level, by introducing a strip of wood in the shape of a sill so that any water on the floor of the bay 
may not intrude upon the living room floor, or by the construction of a shallow groove at this point, connected with the outside of the house so as to carry off any surplus moisture. For, while we are not planning to convert the bay window into an aquatic garden, we do want to make it possible to spray the occupants of the bay thoroughly over, under and through their foliage and, no matter with how fine a spray this is done, more or less water wilk trickle to the floor. Of course the floor must be covered with some waterproof material, tile, cement or even linoleum, but if this can be arranged, it is almost safe to say that one may make a success of almost any variety of plants one wishes to grow, provided there is the proper amount of sunshine and even ordinary care.

We hear a great deal about coal stoves and furnaces being uncongenial sources of heat, and that plants will not thrive where gas is used. I do not agree with this theory in its entirety. I have grown the most delicate flowers successfully in rooms heated with an ordinary coal stove by giving them abundant room to grow, warm south and east windows and showering them thoroughly every day or two. I have also had excellent success with furnace heated rooms, but in this case the furnace used contained a very large and effective water pan in which the water was 
always at the boiling point, so that abundant moisture was supplied to the atmosphere.

Some arrangement for closing off the bay from the adjoining room should be provided, if possible, either in the way of curtains, sliding glass doors or similar means, as this will allow one to regulate the temperature and moisture at will. A register in the bay with a pan of water inside, occupying about half of the opening in the register, is an excellent arrangement, as there is, then, a constant current of warm, moist air arising.

If one wishes to grow a considerable variety of flowers it will be well to fit the tops of the lower sash with shelves for the accommodation of such plants as require a higher temperature, for it must be remembered that heat rises and the top of the sash is much warmer than the sill.

One should never crowd the flowers, no matter what accommodations you are able to give them. Give each plant sufficient room so that no part of it. touches its neighbor; if you have any kind of success with your plants this winter they will grow, and they will blossom, and blossoms need room, not alone to bloom but to exhibit their beauty and this they cannot do if crowded together, and don't, don't, don't waste the energy of your plants by constantly turning them around in a mistaken desire to give each part its supply of sunshine. The plant will at- 
tend to that if you will just leave it alone and, in a few weeks, will present a solid bank of perfect, beautifully colored foliage with buds springing from every twig. No one thing, unless it is poor drainage, will so surely cause the buds of many plants to blast as changing their position when they are coming into bloom.

It is always a misfortune that plants in the house have to receive their light from one side, but, as one's house or bays are usually arranged, this is unavoidable; and the best thing to do is to give the plant room and let it adjust itself.

Another very common mistake in growing houseplants is to give them too large a pot which the plants waste their energy in a vain attempt to fill with roots. Of course there are a few plants which make an excessive root growth, such, for instance, as the Asparagus Sprengeri or the cyperus. These both require large pots and generous feeding to be at their best at any time, while, on the other hand, geraniums, which make a small growth of fibrous root, require rather limited quarters in which to do their best.

It is better to grow plants in quite small pots and shift frequently into those just one size larger as they fill the pots with roots, not before, and always, always give abundant drainage of broken crock, charcoal and sphagnum moss in the bottom of the pots. The bigger the pots the more drainage material is 


\section{MAKING OF A FLOWER GARDEN}

needed, and be sure and leave sufficient room at the top-at least an inch-for watering.

And right here is where the average amateur falls down-in watering her plants. Of course there are people who care enough to grow plants who sometimes forget to water them at all, but the opposite course is more universal and plants are deluged with water day after day whether they need it or not. With facilities for spraying it will not be necessary to water the earth in the pots of any but the most moisture-loving plants, until they are quite dry; then sufficient water should be given to soak thoroughly the ball of earth, so that it runs through into the saucer -which should always be emptied as soon as the drainage has ceased. Sometimes it will be noticed that water runs through at once; this indicates one of two things-either the earth is so filled with fibrous roots that the water cannot penetrate and runs off between the earth and the sides of the pot, or the earth is too hard for it to pass through. In the first place the plants should be repotted or, if this is not practicable, a sharp stick should be run down through the ball, opening up numerous channels for the water, and the surface soil thoroughly stirred. Plants in this condition are much benefited by standing in a basin of water until the earth is thoroughly soaked.

Where it happens that the earth in the pot is hard it should be stirred up from the surface as much as 
possible and watered by standing in a basin of water. Such a condition, however, indicates the use of poor soil, soil containing too little humus, and it would be well to repot with a good compost containing one part leaf mold, one part sharp sand, one of good garden loam and one of old, well-rotted manure.

Plants are in much better condition for watering when the surface soil is kept loose and friable. Plants which have been repotted in good, rich soil in late summer or fall should not need fertilizer during the winter, but where they are growing and blooming freely it sometimes seems called for, and for an indoor fertilizer I have found nothing better than the following.

One and one-half part (ounces or pounds) Nitrate of Soda.

One part (ounces or pounds) Sulphate of Potash. One-half part (ounces or pounds) Phosphate of Soda.

Mix and pulverize the material thoroughly. When required for use put a rounding tablespoonful of the mixture in a gallon of hot water and use when cool in the proportion of a teacupful to a six-inch pot. Of course one may use the commercial fertilizer, which is much cheaper, but the ingredients from the druggist are strictly pure, odorless and go much further. 


\section{MAKING OF A FLOWER GARDEN}

All the asparagus ferns require a fertilizer during winter; indeed the only way to grow these plants indoors is to use fertilizers, for unless this is done the plants require so large a pot as to be unmanageable. Asparagus Sprengeri, when grown in tubs or window boxes out of doors in the summer, makes a magnificent growth and, if potted in fall in a twelveinch pot and kept well watered and fertilized, makes a fine showing all winter and is quite sufficient, in itself, for the decoration of one window or corner of the room. The pot should stand on a pedestal where the long sprays can sweep down unrestrained and one which is easily turned is preferable, for, although this plant requires little light, it should be turned occasionally towards the light to prevent the sprays turning up and backwards.

Another most satisfactory plant for the house is found in the aspidistra. This plant needs only to be potted in good compost, containing a reasonable amount of old, well decayed manure or some bone meal, or both, regularly supplied with water and the leaves kept free from dust by sponging or showering. It does well in almost any window, but probably better in an east or north window where a little sunshine comes. Once established, it should not be disturbed, as it dislikes change. For this reason the pot should not be turned around in the window.

All the primrose family make satisfactory winter 
plants, especially the Baby primroses. These are practically ever bloomers and require only to have the withered flower stalks removed as they fade. Primroses appear to best advantage when grown in window boxes, making that loveliest of all thingsa primrose window. Choose clear scarlets and pure whites by preference. Plunge the pots in boxes, filling in between with sand or sphagnum moss, kept constantly moist and they will be things of beauty all winter. Do not overwater and see that the drainage in the pots is sufficient and that the crown of the plants stands rather high in the pot, so that water may run from, rather than settle around, the crown, but always allow an inch of space between the soil and the top of the pot in potting any plant, for the necessary watering.

Calceolarias and cinerarias are most satisfactory plants for winter blooming, as they are certain of bloom and easily cared for. Cinerarias are apt to be infested with green lice and for this must be sprayed with tobacco tea, or if not in bloom may be treated with hot water-at about $136^{\circ}$ if the plant is to be dipped, which should always be done if practicable, or $140^{\circ}$ if used as a spray. The hot water bath may be used in place of insecticides in nearly all cases of infected plants with superior results. The hot bath not only kills all insect life, but also cleanses and refreshes the foliage. It is sure 


\section{MAKING OF A FLOWER GARDEN}

death to the red spider-that pest so difficult to dislodge. In using fill a large pail or dish, place a cloth or paper over the soil and place the hand on this, straddling the stem of the plant and dip the entire plant in the water, holding it there at least a minute or while you count sixty.

Almost all greenhouse plants may be grown from seed started in flats in the house in early spring or in flats in a hotbed, potted off as soon as large enough to handle into thumb pots and plunged in boxes of wet sand in the open air in a sheltered positionon the east side of the house, if possible. They should be shifted into larger-just one size larger-pots as they fill with roots until by fall they should be in six-inch pots and full of buds ready for winter blooming. Where one has a penchant for geraniums it will be well worth while to plant seed of Lady Washington or Pelargonium geraniums in spring for winter blooming. These are so much finer than the zonale geraniums and so much more certain to bloom that they should always find a place in the winter window garden,

If one has a few palms, aspidistras and ferns, then one may supply blossoming plants by planting freely of spring blooming bulbs such as tulips, narcissus, hyacinths, crocus and the like. Begin planting in September and continue until the first of December, planting in window boxes, by preference, but putting 
a considerable number of Easter lilies, nareissus and like tall-growing things in pots-at least three large bulbs of narcissus or tulips in a four-inch pot. Place these in a cool dark cellar until the pots fill with roots and growth shows above ground, then bring up in relays as needed. In this way one may have abundance of the loveliest flowers all winter, and these forced bulbs have a freshness and spring-time beauty not approached by any other class of plants. They are perfectly certain of bloom, inexpensive and of such easy culture as to be perfectly safe for the amateur to undertake.

As far as possible plants should be protected from a low temperature at night but this should be done by making the windows secure against draught and keeping the temperature of the room above freezing rather than by. moving them out of the windows at night-an undertaking full of annoyance and labor and likely to result in more or less damage to plants. A night temperature of about fifty degrees will keep plants in good shape. Should plants become frosted, however, they should be at once removed to a cool dark room where the temperature can be lowered to barely above freezing, until they thaw out, or they may be taken to a cold bath room and sprayed with water not over 33 degrees. After being frozen all injured leaves and twigs should be removed and the plant brought into as rapid growth as possible. 


\section{CHAPTER XX}

\section{PLANT ENEMIES AND INSECTICIDES}

From the burgeoning of the first leaf until the laying aside of the garden after the completion of its season of growth, all sorts of enemies dispute the possession of flower and leaf. We plant a garden in April fondly cherishing the happy delusion that it belongs to us, but, apparently, this is not the case, as every bug and worm and beetle and fly known to science claims squatter's-right to the free enjoyment of our possessions.

Almost the first pest to put in appearance will be aphis of all sorts and colors, but of a uniformly ravenous appetite. Usually the first plants to be affected will be the roses. These, indeed, may be said to set the pace for the garden pests, for, first or last, nearly all those which make life a burden for the gardener make their initial appearance in the rose bed.

The aphis first appears as a fly, a tiny, and, under the microscope, a beautiful creature of gauzy wing and slender body. In some species of aphis eggs 
are laid by this winged female, which in turn hatch into other egg-laying creatures. In some cases the young produced in the first few broods are viviperous, that is, they are produced alive, a complete insect and only the last brood of the season are produced from eggs which remain in erevices of the bark of the plant until the following spring, when they hatch, producing the winged female of the first appearance. The result, as far as the plants are concerned, is the same, the rapid destruction of the foliage and serious injury of the plant. There are several remedies which may be resorted to, both as remedial and as preventive measures. Tobacco dust sprinkled over the young shoots before the leaves develop will often keep them in check. The hot-water bath is effective after they have gained a foot-hold, and where the bushes are of sufficient size to be dipped into a basin of hot water, forms one of the most effectual and satisfactory remedies used. In using water for dipping it should not exceed one hundred and thirty-five degrees in heat, a somewhat higher temperature being practicable when used as a spray. Plants can stand a hot water bath which is death to all soft bodied insects. Kerosene emulsion, if care is taken not to use it of sufficient strength to burn the foliage, is usually efficient on all but the gray lice; for this variety of louse I have found nothing really fatal. They infest my honeysuckle and defy all the insecticides I can bring 


\section{MAKING OF A FLOWER GARDEN}

to bear upon them. I think they are some special breed sent to keep me humble.

Rose slug-small green caterpillars which feed on the underside of the leaves or draw two leaves together as a shelter while they eat out the buds from the tips of the shoots-are usually the next pest to put in an appearance. These may be destroyed by hand-picking or by spraying the underside of the leaves with whale oil solution, or dusting with hellebore when the foliage is damp.

Rose thrips are more troublesome than any other insect, as they leave the plant at the least disturbance, returning when all is quiet to complete their work. Whale oil soap syringed on the underside of the leaves is the best remedy. Readana sprayed on and under the foliage at intervals of a few days for two or three applications will usually remove them for the season.

Red spider, which affects all hard wooded plants at times, can only be kept at bay by a moist atmosphere, as this particular insect thrives in a dry, hot atmosphere, but once it has gotten a foothold, there is no better remedy than the hot water bath. Spraying with Fir Tree oil is also effectual.

Aster beetles are quite sure to put in an appearance as soon as the flowers show bloom. The practical remedy here and in the case of rose bugs, is hand picking. These bugs are sluggish insects and if 


\section{PLANT ENEMIES AND INSECTICIDES 211}

they are picked and dropped in a pan of water con. taining a little kerosene, early in the morning, when they are still sluggish, they will soon be disposed of. Where this is considered too tedious the plants may be sprayed with either Paris green solution or arsenate of lead.

Mildew on roses, sweet peas and other flowers is usually controlled by shaking flour of sulphur over the plants when they are wet with dew. In hot, muggy weather one should not water late in the afternoon plants inclined to mildew. All fungoid diseases indicated by the browning or spotting of the foliage should be handled with a spray of Bordeaux mixture, getting the wash onto every part of the plant and repeating two or three times in the season. Roses, hollyhock, clematis, foxgloves and many other plants are subject to various fungoid diseases and it is a good plan to spray all plants known to be susceptible before the blight appears.

Aquilegias, asters, cosmos and dahlias are much troubled with a little worm which invades the stalk just below the surface of the soil. In the case of the aquilegia this is a little pink worm about half an inch long which excavates a nest in the crown of the plant where it changes into a chrysalid and takes its winter nap. Its presence is first detected by the wilting of the top of the plant when it is usually too late to save the plant. If the plant is taken hold of 


\section{MAKING OF A FLOWER GARDEN}

by the top it will often come entirely away, revealing the worm and its nest. Sometimes there is sufficient growth about the lower side of the crown to supply a new plant and it is only necessary to destroy the worm. When the plant has just begun to wilt if the entrance hole of the worm is found and a sharp wire or hairpin introduced, the worm can be found and killed and often the plant will recover. The earth should always be drawn up above the wound. The treatment is the same for all plants affected with borers and the preventive measure is to pour Paris green solution about the roots of the plants at intervals from the time they are set until fully grown.

Where asters have been affected with what is known as the "aster disease" they should not be planted in the same ground again for two or three years.

In treating plants for insects of any and all kinds it may be simplified by remembering that for all bugs, worms or lice which eat the plants Paris green or arsenate of lead is the standard remedy, but that these insecticides are powerless against those which do not eat the tissue of the plants but merely suck their juice. For these and all soft bodied pests, kerosene emulsion is the remedy; this and hot water. For all hard shelled beetles and scale the caustic washes like whale oil, caustic potash, lime sulphur solution and the like are best.

While formulas are given for the preparation of all 


\section{PLANT ENEMIES AND INSECTICIDES 213}

insecticides it will be much easier for the amateur to buy the various preparations on the market and use according to directions.

Kerosene emulsion paste, ready to use by adding water, and Bordeaux mixture and lime sulphur wash are especially handy to use and save a tedious preparation.

\section{INSECTICIDES}

Paris Green. Use 1 pound with an equal amount of thoroughly slaked lime in from 100 to 300 gallons of water and keep thoroughly stirred when using.

ARsenate of Lrad. Use the prepared paste form at the rate of one pound to fifty gallons of water.

Kerosene Emulsion. Dissolve one-half pound of soap in one gallon of boiling water, add two gallons of kerosene and force through a force pump repeatedly until it forms a milk-like emulsion. Add twenty-five gallons of water and use. If allowed to stand for any length of time it must be re-churned with the pump, as the oil will have separated somewhat from the water. Use rain water for mixing. Where it is necessary to use hard water, milk should be substituted for the soap, using one gallon of milk to two of kerosene or substitute quarts for gallons in small gardens.

Combined Insecticide and Fungicide. Mix four ounces Paris Green or one pound of Arsenate of Lead 


\section{MAKING OF A FLOWER GARDEN}

with fifty gallons of Bordeaux mixture and use for spraying rose bushes, and all plants addicted to fungoid disease and the attacks of leaf-eating insects. In using Bordeaux it is best to buy the commercial preparation.

HELLEBORE.-Mix thoroughly one ounce of fresh white hellebore and three gallons of water.

These few formulas if persistently used will be sufficient to keep the garden free from insects of all kinds but must be used in season to be of value.

Wood alcohol, used in full strength with an atomizer, is another very effectual insecticide for any insect with which it comes in contact and is especially valuable in the rose garden. It has the advantage of being convenient to use, as the atomizer can be kept in one's garden basket or even slipped in the pocket and so be at hand to use when one notices the presence of insects on the plants. 


\section{CHAPTER XXI}

THE VALUE OF A DEFINITE COLOR SCHEME IN THE GARDEN

THE idea which seems to prevail in most gardens is to fill it with flowers and still more flowers, adding whatever caprice of the moment dictates or whatever novelty happens to strike the fancy from time to time. The color relations which these new additions may bear to the old inhabitants of the garden is apparently little thought of, if indeed it ever occurs to the owner of the garden that as long as a flower is a flower and has individual merit there can be any possible objection to its presence; in fact, with the average gardener, it seems really to be a matter of pride to possess as many varieties of plants as possible. But one has not learned the true art of gardening until one learns to hold his hand and to go slowly when adding to a garden's store.

Especially is this true when the garden, as it exists, is a happy expression of color and beauty. It is a safe conclusion that the average garden should be subtracted from rather than added to. If the garden in its entirety is the result of carefully 


\section{MAKING OF A FLOWER GARDEN}

thought out plans then there is little need of caution, as the owner is not apt to run amuck among strange flowers of unknown colors, but even here it is well to pause and consider whether it is not well to let well enough alone; at least one should always take the precaution of informing himself as to just the color and shade of all new introductions to the garden. A trial garden is perhaps the most valuable possession a gardener can have. Here plants may be grown experimentally, and transferred to the permanent garden as they prove their fitness, and given just the conditions and environment that will bring out their good points to perfection.

To emphasize the value of a color scheme one has but to think of various inharmonious colors and imagine them together, not for one day or for several but for the entire season of their bloom, through a succession of years. It is not bad color work that a number of colors should occur in any one garden but it is bad work when several tones of a color clash. As an example, blue and red may appear in the same garden with much less discord than scarlet and magenta. If one has no color scheme and is at a loss to invent one a visit to the milliner's and the massing together of quantities of flowers will very soon demonstrate how much better the effect of the proximity of certain colors is than of others, and having determined this one may lay plans accord- 


\section{A COLOR SCHEME IN THE GARDEN 217}

ingly. When one desires a great diversity of color then one must remember that white is a great peacemaker and intersperse white flowers liberally between any shades that have the least taint of enmity. - -

It is seldom the case that one needs to discard a favorite flower because of an inharmonious shade, as nearly all flowers come in a wide diversity of colors and tones and emong these one may select a suitable one.

Where one is uncertain as to what to use or what he really wishes in color the adoption of some one color-say, yellow-with white will produce a charming color effect to which another year, if one's taste has sufficiently crystallized, one may add another color, say, blue or pink, and have a color scheme that should be satisfying in the extreme. But the use of one color in a garden is a fascinating development of color work and through its adoption one learns much of the possibilities along these lines, makes the acquaintance of many heretofore unknown members of old families of flowers and finds it altogether a de: lightful study.

Or one may have a definite color scheme for each season of the year-spring, fall-and fill the early garden with masses of brilliant colored tulips of the desired color-scarlet or soft pink-with hyacinths to correspond and the white of crocus and other bulbs, while the summer garden may be emphasized with 
blue of iris, delphiniums, monkshood, forget-me-nots, anchusas, blue pansies, bachelor buttons, browallias, lobelias and the like, and the fall garden may be gorgeous with the yellow and white of chrysanthemums, dahlias and golden glow.

It will be found immensely interesting to take the catalogues and make a list of all the flowers of a certain color, together with their time of blooming. It will be found, for instance, that there are a great many more blue flowers than one supposed, and the same is true of the other colors, so that if one has a preference for certain colors he will be surprised to find how liberally the florists are catering to that preference.

A garden which has several divisions or is cut up by shrubbery, arbors or hedges offers admirable opportunity for color work, as the separate parts can be devoted to separate color schemes rather than to separate flowers. This would add immensely to the interest of a garden and is worthy of serious consideration in planning a new garden.

There is another arrangement of a color scheme which might appeal to some, and that is the shading of beds and borders of plants. This requires a thorough knowledge of the shades of color of the flowers employed or the aid of an experienced florist, but very pretty effects can doubtless be obtained by the use of flowers of a given color shaded from the palest 


\section{A COLOR SCHEME IN THE GARDEN 219}

tints down to the strongest tones obtainable. Pansies afford an excellent opportunity for this form of planting and delphiniums another, as these shade from purest white and pale blue down to the strongest ultramarine. Roses give an infinity of shade gradations and some very successful color rchemes may be worked out with this flower. Where one has the knack of so growing roses that they will give a mass of bloom at one time the rose garden laid out in concentric beds, surrounding a central bed of tree roses is excellent, the roses shading from a rich, dark crimson of the center trees down through successive shades to pale pink or pure white, as the case may be, at the outer edge. Or the center may be white, shading to dark red at the outer circle.

Often it will be found necessary to employ more than one variety of flowers to produce the desired color gradation but this only adds to the interest and tests one's knowledge of flowers or adds immensely." to it.

There is another point to be borne in mind in planning the color effects of the garden and that is the effect color has on the apparent dimensions of the garden. The presence of white always brings the planting nearer the eye, while blue retires it so that where the effect of space is to be increased, as in small gardens, it will be wise to plant the white and bright colors near the front of the garden using such 


\section{MAKING OF A FLOWER GARDEN}

colors as lavender, mauves and especially blues for the rear beds, as this will make them appear farther away and so increase the apparent dimensions.

Again, if one wishes to enjoy the novelty of a garden of one color for a single season one may plant as many different plants of the desired color as are available and so form a wide working acquaintance with the possibilities of that color and if, at the end of the season, one finds that interest flags or that so much of one color has become oppressive, then those plants which least appeal to one's interest or taste may be discarded and their place filled with white or some other harmonizing color. It is rarely that one will wish to discard a really good perennial, nor will one easily tire of any good white, and white is the one color that one can take long chances with-it seldom needs uprooting to keep the garden peace.

If one has room for experimental beds or borders where flowers of one color can be grown for two or more seasons-so that the perennials may have time to express themselves-then the best of these may, in time, find their way to the permanent garden either to form a one-color scheme or to add their color note to the mixed garden. 


\section{A COLOR SCHEME IN THE GARDEN 221}

\section{PLANTING TABLE FOR BLUE GARDEN}

\section{NAME}

Aconitum Napellus . . . . . . . . . June-July

Ageratum-" "Little blue star"... All summer

"Blue perfection"............All summer

"Princess Pauline"............. All summer

Anchusa italica. ............ May-June

Aquilegia corulea..............July

Browallia, speciosa major........Mid-summer and

Brachycome.............. All summer

Caryopteris . .................. Sept.-frost

Canterbury bell............... June-Aug.

Cornflower, cyanus............July-Sept.

Convolvulus ................. All summer

Dwarf convolvulus............. All summer

Japanese convolvulus, juno... All summer

Eryngium ................. July and Sept.

Eehinops ritro............. July-Sept.

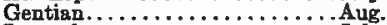

Lavender.................... July-Aug.

Lindelofia.................May

Linum....................... All gummer

Lithospernum........................

Larkspur...................July-frost

Lupin....................May-June

Lobelis . . . . . . . . . . . . . . . . June-Nov.

Maurandia. . . . . . . . . . . July-frost

Myosotis..................... May-Oct.

Platycodon.................July-Aug.

Salvias-Aqurea. . . . . . . . . . . Aug-Sept.

Pitcheri................Aug-Sept.

vliginosa.................. June-frost

Virgata. .................June-July

Stokesias. . . . . . . . . . . . . . . . . July-frost

Violas. . . . . . . . . . . . . . . . June-frost

HEIGHT
$3^{\prime}-5^{\prime}$
$4^{\prime \prime}-5^{\prime \prime}$
$4^{\prime \prime}-8^{\prime \prime}$
$8^{\prime \prime}$
$3^{\prime}-5^{\prime}$
$2^{\prime}$
$2^{\prime}$
$9^{\prime \prime}-1^{\prime}$
$3^{\prime}$
$6^{\prime \prime}-5^{\prime}$
$2^{\prime}-3^{\prime}$
$20^{\prime}$ vine
$1^{\prime}$
$20^{\prime}-30^{\prime}$
$2^{\prime}-3$
$2^{\prime}-3^{\prime}$
$2^{\prime}$
$2^{\prime}$
$2^{\prime}$
$2^{\prime}$
Creeping
$2^{\prime}-3^{\prime}$
$18^{\prime \prime}$
$6^{\prime \prime}-15^{\prime \prime}$
$10^{\prime \prime}$
$9^{\prime \prime}-10^{\prime \prime}$
$18^{\prime \prime}$
$13^{\prime}-4^{\prime}$
$3^{\prime}-4$
$5^{\prime}-6^{\prime}$
$18^{\prime \prime}$
$18^{\prime \prime}$
$6^{\prime \prime}-9^{\prime \prime}$

CLASS

Perennial

Annual

Annual

Annual

Perennial

Perennial

Perennial

Annual

Perennial

Perennial

Perennial

Annual

Annual

Annual

Perennial

Perennial

Perennial

Perennial

Perenniel

Perennial

Perennial

Annual

Perennial

Perennial

Perennisl

Annual

Perennial

Annual

Perennial

Perennial

Perennial

Perennial

Perennial

\section{PLANTING TABLE FOR RED GARDEN}

NAME SEASON HEIGHT

Agrostemma--Flos Jovis. . . . . . Jupe-July

Coronaria. ............... June-July

Amaranthus-Cordatus, .........June-July

Cruentus . ............... June-July

Antirrhinum tali ................ July-Sept.

Half-dwarf. . . . . . . . . . July-Sept.

Armeris Formosa. . . . . . . . . All summer

Apters, in variety. ...............

Althes-" Duchess de Brabant". Sept.-Oct.

"Rubis"................. Sept.-Oct.

Anemone-Japonica rubra...... Sept.-Oot.

"Prince Henry". . . ........... Sept.-Oct.

Aubretia Leichtlini. . . . . . . . . . . May-June

Balsam. . . ................ All summer

Begonia Erfordia.................All summer Luminosi, Vernon...........All summer

Candytuft.................. June

Cardinal olimber............ July-frost $12^{\prime \prime}$

$3^{\prime}-5^{\prime}$

$3^{\prime}$

$3^{\prime}$

$18^{\prime \prime}$

$12^{\prime \prime}$

$18^{\prime \prime}-2^{\prime}$

$12{ }^{\prime}-15^{\prime}$

$12^{\prime}-15^{\prime}$

$2^{\prime}-3^{\prime}$

$2^{\prime}-3$

Dwarf

$18^{\prime \prime}-2^{\prime}$

$12^{\prime \prime}-15^{\prime \prime}$

$12^{\prime \prime}-15^{\prime \prime}$

$30^{\prime}$ $2^{\prime}-3^{\prime}$
VARIETY

Perennial

Perennial

Annual

Annual

Annual

Annual

Perennist

Annus

Perennial

Perennial

Perennial

Perennial

Perennial

Annual

Annual

Annugl

Annual

Annual 
PLANTING TABLE FOR RED GARDEN (Continued)

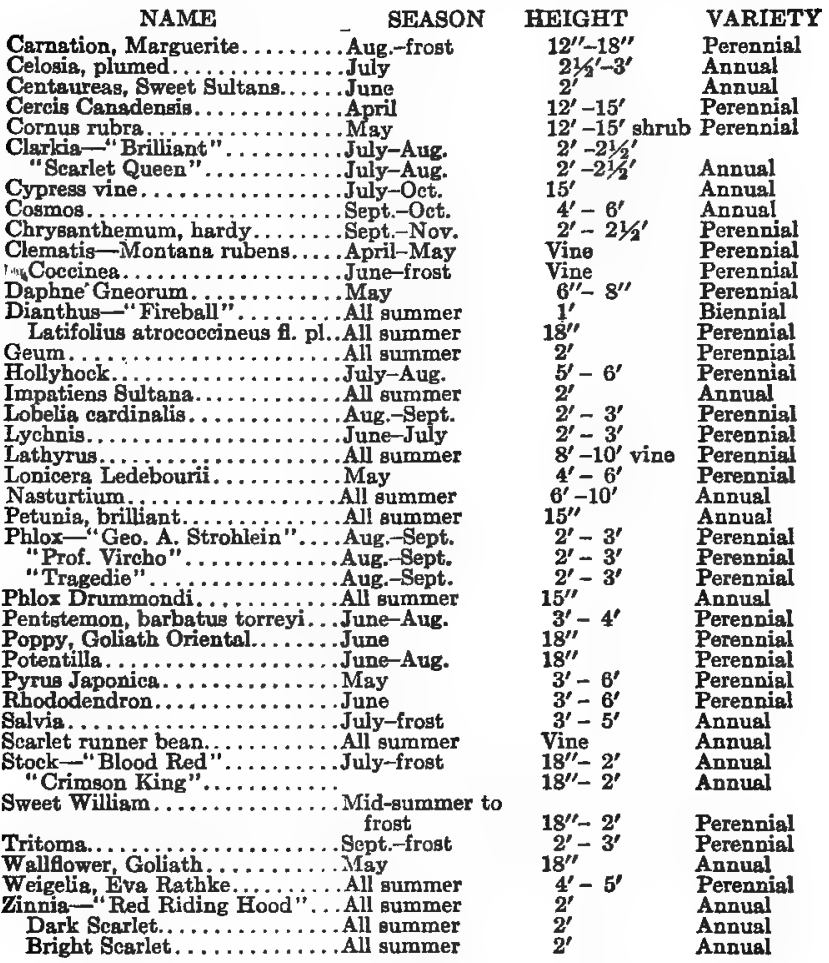

\section{PLANTING TABLE FOR WHITE GARDEN}

\section{NAME}

Antirrhinum-Giant white......July-Nov. "Mount Blane". . . . . . . . . . July-Nov.

Adlumia cirrhosa. . . . . . . . . . July

Achillea Ptarmica . . . . . . . . . . All summer

Acroclinium Napellus. . . . . . . . . All summer

Ageratum, Imperial dwarf white. All summer

Alyssum, Little Gem......... All summer

HEIGHT
$3^{\prime \prime}$
$18^{\prime \prime}-3^{\prime}$
$18^{\prime \prime}$
$2^{\prime}$
$15^{\prime \prime}$
$8^{\prime \prime}$
$4^{\prime \prime}$

VARIETY

Annual

Annual

Biennial

Perennial

Annual

Annual

Annual 


\section{A COLOR SCHEME IN THE GARDEN 223}

\section{PLANTING TABLE FOR WHITE GARDEN (Continued)}

\begin{tabular}{|c|c|c|}
\hline 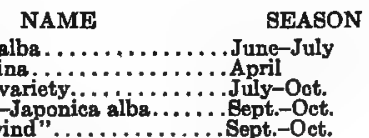 & $\begin{array}{l}\text { HEIGHT } \\
18^{\prime \prime} \\
6^{\prime \prime} \\
18^{\prime \prime} \\
2^{\prime}-3^{\prime} \\
2^{\prime}-3^{\prime}\end{array}$ & $\begin{array}{l}\text { VARIETY } \\
\text { Perennial } \\
\text { Perennial } \\
\text { Annual } \\
\text { Perennial } \\
\text { Perennial }\end{array}$ \\
\hline
\end{tabular}

Aquilegia alba..............June-July

Arabis alpina..$\ldots \ldots \ldots \ldots \ldots$. April

Asters, in variety. . . . . . . . . . . July-Oot.

Anemone-Japonics alba...... Bept.-Oet.

"Whirlwind"

teum..................... May

Armerib alba............... All summer

Astilbe, white peari.............. June-July

Althea, Jeanne d'Arc.......... Sept-Oot.

Andromeda-Floribunda....... May

Japonica. ...............May

Aralia opinoss...................

Azalea Japonick alba. . . . . . . . . May-June

Balsam, white perfection....... July-Aug.

Bocconia cordata............. July-Aug.

Boltonia asteroides............July-Sept.

Bellis (English daisy) .............. All summer

Calendula, pongei $\mathrm{f}$. pl.......... Late summer and fall

Canterbury bell............ July

Campanula carpataca............ All summer

Cornflower ..................All summer

Candytuft, Empress................ summer

Chrysanthemum-

"King Edward" . . . . . . . . . Fall

"Inodorum". . ............... Mid-summer to frost

Shasta Daisy, Alaska........ July-Oot.

Clarkis alba fl. pl............... June-July

Cleome alba. . ............ July-Aug.

Cosmos, Lady Lenox........... Sept.

Convalieria (Lily of Valley)...... May

Chionanthus..................June

Clethra . . ................ July-Aug.

Crategus Oxyacanths. . . . . . . May

Clematis-Paniculata.......... Sept.

Montana grandiflora........... April-May

Virginiana ..................

Recta f. pl...............June-July

Delphinium album. ..........July-Sept.

Digitalis................... June-July

Datura (Brugmansia) . . .......... Late summer

Deutzias, in variety. ........... June

Hibiscus, Crimson Eye........ . July-Aug.

Hollyhock ................... July-Aug.

Ipomea- "Grandifiora; ......... June-frost

"Japanese-Aphrodite " . . . . . . July-frost

Iris, in variety.................June-July

Lobelig, white gem.............June-Nov

Lupine...................... May-June

Lillum-Candidum.............. June

Auratum................July

Speciosum album..........July

Lilac-Vulgaris alba.............. May

"Mme. Cassimir Perier"...... May-June

"Ligustrum Ibots" (Jap.

Privet)................. June-July

$18^{\prime \prime}$

g"

$12^{\prime}-15^{\prime}$

$2^{\prime}-4^{\prime}$

$4^{\prime}-6^{\prime}$

$12^{\prime}-15^{\prime}$

$18^{\prime \prime}-2$

$18^{\prime \prime}-2$

$4^{\prime}-6^{\prime}$

$4^{\prime \prime}-6^{\prime \prime}$

$1^{\prime}$
$3^{\prime}$
$6^{\prime}$
$2^{\prime}$
$9^{\prime \prime}$

$2^{\prime}$

$2^{\prime}$

$15^{\prime \prime}-18^{\prime \prime}$

$2^{\prime \prime}-30^{\prime \prime}$

$316^{\prime}$

$4^{\prime}-6^{\prime}$

$\theta^{\prime \prime}$

$6^{\prime}-8^{\prime}$

$4^{\prime}-5^{\prime}$

$12^{\prime}-15^{\prime}$

Vinu

$20^{\prime}$ vine

$20^{\prime}$

$2^{\prime}-3^{\prime}$

$18^{\prime}-2^{\prime}$

$3^{\prime}$

$3^{\prime}-5^{\prime}$

$5^{\prime}-6^{\prime}$

$4^{\prime}-5^{\prime}$

$5^{\prime}-6^{\prime}$

$20^{\prime}$

30

$2^{\prime}-3^{\prime}$

6

' 2 '

$2^{\prime}-3^{\prime}$

$3^{\prime}-4^{\prime}$

$2^{\prime}$

$6^{\prime}-12^{\prime}$

$6^{\prime}-8^{\prime}$

$6^{\prime}-8^{\prime}$
Perennial

Perennial

Perennial

Perennial

Perennial

Perennial

Perennial

Annual

Perennial

Perennial

Perennial

Annual

Perennial

Perennial

Annual

Annual

Perennial

Perennial

Perennial

Annual

Annual

Annusi

Perennial

Perennial

Perennial

Perennial

Perennial

Perennial

Perennial

Perennial

Perennial

Perennial

Perennial

Perennial

Perennial

Perennial

Annusl

Annual

Perennial

Annual

Perennial

Perennial

Perennial

Perennial

Perennial

Perennial

Perennisl 


\section{MAKING OF A FLOWER GARDEN}

\section{PLANTING TABLE FOR WHITE GARDEN (Continued)}

NAME SEASON HEIGHT VARIETY

Lonicera (Bush Honeysuckle) -

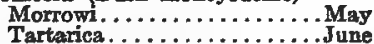

Lathyrus, White Pearl..........All summer Nicotiang affinis...............All summer Pansy - "Giant Snow Queen"... All summer "Giant Bnow White".........All gummer

Petunia-Snow Ball.............All Bummer Pure White...............All summer

Phloz Drummondi.............. All summer Pblox amcena............... April-May Bubulata alba................April-June "Diadem"................July-Sept.

"Mrs. Jenkins". . . . . . . . . July-Sept.

"Jeanne d'Arc".............July-Sept.

Physostegia alba. ..............Mid-summer

Platycodon.................... July

Polygonum auberti........... Late summer and fall

Pyrethrum uliginosum atellata. .Aug.-Sept.

Philadelphus................June

Rodgerga...................... All summer

Schirophragma hydrangeoides...June-July

Stenanthiun ..................Aug.-Sept.

Spirzea-Aruncus..............June-July

Filipendula.............June

Ulmaris.................. June-July

Stokesia.. ............... Sept.

Thalictrum dipterocarpum.......Aug.-Sept.

$\begin{array}{cl}6^{\prime} & \text { Perennial } \\ 6^{\prime} & \text { Perennial } \\ 8^{\prime}-10^{\prime} & \text { Perennial } \\ 2^{\prime}-3^{\prime} & \text { Annual } \\ 9^{\prime \prime} & \text { Perennial } \\ 9^{\prime \prime} & \text { Perennial } \\ 12^{\prime \prime} & \text { Annual } \\ 12^{\prime \prime}-15^{\prime \prime} & \text { Annual } \\ 9^{\prime \prime} & \text { Annual } \\ 4^{\prime \prime} & \text { Perennial } \\ 4^{\prime \prime} & \text { Perennial } \\ 1^{\prime} & \text { Perennial } \\ 3^{\prime} & \text { Perennial } \\ 216^{\prime} & \text { Perennial } \\ 4^{\prime}-6{ }^{\prime} & \text { Perennial } \\ 2^{\prime}-25^{\prime} & \text { Perennial }\end{array}$

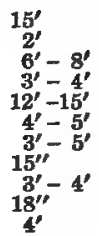

Perennial

Perennial

Perennial

Perennial

Perennial

Perennial

Perennial

Perennial

Perennial

Perennial

Perennial

\section{PLANTING TABLE FOR YELLOW GARDEN}

\begin{tabular}{|c|c|c|}
\hline SEASON & HEIGHT & CLASS \\
\hline 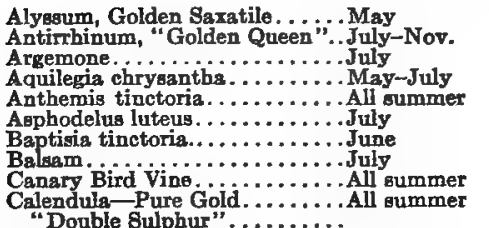 & $\begin{array}{l}1^{\prime} \\
18^{\prime \prime}-21 / 2 \\
3^{\prime} \\
2^{\prime}-21 / a^{\prime} \\
15^{\prime \prime} \\
3^{\prime} \\
2^{\prime} \\
2^{\prime} \\
6^{\prime}-8 \\
1^{\prime}\end{array}$ & $\begin{array}{l}\text { Perennisl } \\
\text { Annual } \\
\text { Perennial } \\
\text { Perennial } \\
\text { Perennial } \\
\text { Perennial } \\
\text { Perennial } \\
\text { Annual } \\
\text { Annual } \\
\text { Annual }\end{array}$ \\
\hline 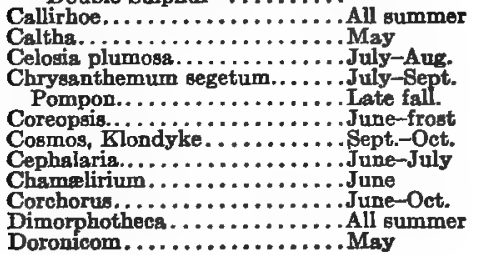 & $\begin{array}{l}9^{\prime \prime}-12^{\prime \prime} \\
1^{\prime} \\
2^{\prime}-26^{\prime} \\
3^{\prime} \\
2^{\prime} \\
2^{\prime \prime} \\
4^{\prime}-6^{\prime} \\
6^{\prime} \\
2^{\prime} \\
6^{\prime}-8^{\prime} \\
12^{\prime}-15^{\prime} \\
1^{\prime}-3^{\prime}\end{array}$ & $\begin{array}{l}\text { Perennial } \\
\text { Perennial } \\
\text { Annual } \\
\text { Annual } \\
\text { Perennial } \\
\text { Perennial } \\
\text { Annual } \\
\text { Perennial } \\
\text { Perennial } \\
\text { Perennial } \\
\text { Perennial } \\
\text { Perennial }\end{array}$ \\
\hline
\end{tabular}




\section{A COLOR SCHEME IN THE GARDEN 225}

\section{PLANTING TABLE FOR YELLOW GARDEN (Continued)}

\section{NAME}

Eschecholtzi

Erysimum..................All summer

Epimedium sulphurum.........All gummer

Helianthus, in variety.......... June-frost

Hollyhoek...................July

Hunnemannia.................July

Hemerocallis. ......................

Heliopsis. ................... Aug.-Oct.

Hypericum.................. All summer

Iris-Ochroleucs. . . .......... May

Aurea................... May

Psoudacorus...............June

Marigold................July-Aug.

Iysimachia-Ciliata.............July

Punctata.....................

Portulaca....................All summer

Rudbeckia fulgida............. Aug.-Sept.

Ranunculus. . ................ May-June

Sanvitalia. . ..................All aummer

Stock........................ July - frost

Senecio-Veitchianus. .......... July-Aug.

Clivorum. . . . ............July-Aug.

Silphium..................... Aug. Sept.

Tagetes..................... All summer

Thermopsis...................June-July

Thalictrum ................July-Aug.

Tritoms sulphurea............ Aug.-Sept.

Trollius Europseus.............. May-July

Viola, Luteus Splendons........ June-frost

Zinnias..................... June-frost

$\begin{array}{cl}\text { HEIGHT } & \text { CLASB } \\ 12^{\prime \prime}-18^{\prime \prime} & \text { Annual } \\ 18^{\prime \prime} & \text { Perennial } \\ 8^{\prime \prime}-10^{\prime \prime} & \text { Perennial } \\ 1^{\prime}-7^{\prime} & \text { Annual } \\ 1^{\prime}-7^{\prime} & \text { Perennial } \\ 2^{\prime} & \text { Annual } \\ 2 y^{\prime}-5^{\prime} & \text { Perennial } \\ 3^{\prime}-5^{\prime} & \text { Perennial } \\ 2^{\prime} & \text { Perennial } \\ 2 y^{\prime} & \text { Perennial } \\ 3^{\prime} & \text { Perennial } \\ 4^{\prime} & \text { Perennial } \\ 18^{\prime \prime}-2^{\prime} & \text { Annual } \\ 2^{\prime} & \text { Perennial } \\ 2^{\prime}-3^{\prime} & \text { Perennial } \\ 6^{\prime \prime} & \text { Annual } \\ 3^{\prime} & \text { Perennial } \\ 2^{\prime} & \text { Perennial } \\ 6^{\prime \prime} & \text { Annual } \\ 1^{\prime \prime \prime}-15^{\prime \prime} & \text { Annual } \\ 2^{\prime} & \text { Perennial } \\ 3^{\prime} & \text { Perennial } \\ 6^{\prime}-8^{\prime} & \text { Perennial } \\ 1^{\prime} & \text { Annual } \\ 3^{\prime} & \text { Perennial } \\ 3^{\prime}-4^{\prime} & \text { Perennial } \\ 2^{\prime} \mathbf{y}^{\prime} & \text { Perennial } \\ 2^{\prime} & \text { Perennial } \\ 6^{\prime \prime}-9^{\prime \prime} & \text { Perennial } \\ 12^{\prime \prime}-18^{\prime \prime} & \text { Annual } \\ & \end{array}$




\section{CHAPTER XXII}

BIRD HOUSES, NATATORIUMS AND FEEDING STATIONS

FEw things add so charmingly to the interest of the home grounds as the presence of birds, especially those more attractive species that require some special provision for their comfort in the way of nesting places, abundant food supply and the presence of water for drinking and bathing, and all in a position that insures a moderate degree of safety for their enjoyment.

The robin, the blue jay, the cat bird and the English sparrow we have with us always. The flicker or high-holer (or any one of the friendly, intimate names by which this big fellow of the woodpecker family is known) is common on most lawns. The mourning dove, that most exquisite member of the family, is common wherever trees for the construction of its slovenly-built nest grow-usually a pear tree or an evergreen will be its choice-while the oriole hangs its pensile nest from the outermost tips of the maple trees. But the little house wren, the bluebird and the martin will not make their homes with us unless 


\section{BIRD HOUSES AND NATATORIUMS 22\%}

suitable domiciles are provided for their occupancy and these must be in position early in the spring, before the return of the birds. That, in the case of the bluebird, will be any time in March, so that the houses should be up by the end of February. Martins come later and once supplied with an acceptable house will return year after year to the same abode.

Unlike the bluebird they are not driven away by the sparrows, paying absolutely no attention to their attacks. A pair of martins came the past summer to a five-room house on my lawn which was intended for bluebirds, but these had been driven away by the sparrows. The martins tried to gain entrance through the small openings; the sparrows attacked them vigorously but the martins never even turned their heads to look at them and only left when they found the entrance too small for them.

Martins require an entrance hole about two inches in diameter and the inside diameter should be at least the length of the bird-at least six inches square or better still six by eight inches-and the house must be many roomed, for martins always nest in colonies, never singly. Bluebirds will nest singly or in apartment houses and wrens are solitary or gregarious as circumstances decide. Last year wrens and English sparrows occupied, quite peacefully, the same house, a ten-room structure in an especially inviting position between a large mulberry and a big pear tree. One 


\section{MAKING OF A FLOWER GARDEN}

fateful summer a poor little wren, who had, in some tragic way, lost his mate, after days of mourning and calling for her, made an alliance with a little hen-sparrow and set up housekeeping in a box under the eaves and $I$ was much surprised the following fall to hear some unmistakable wren notes issuing from the throat of an undersized little cock-sparrow. On examining the nest it was curious to observe how the traditions and instincts of each class of birds had been adhered to in its construction, the feathers so dear to the heart of a sparrow, and the evergreen twigs, without which no wren considers its nest complete, being about equally evident, and the crowning touch of a wren's nest-spider eggs, with which he always decorates his nest-were much in evidence.

If one wishes to attract birds to build about the lawns and buildings it will be well to know first the habits of the different birds; which are terrestrial, building in trees and those that are given to nesting in boxes, on brackets and in buildings. It is also well to consider those that build in brush heaps, as the brown thrush, or thrasher, as it is commonly called; those preferring brambles, as the cat bird, and indigo bunting, which much affect the blackberry bushes; and those choosing ledges in porch and out buildings, as, for example, the phoebe. One pair of phoebes have had a nest on a stringer in the woodshed where I am constantly going in and out. Last year 
the male bird only appeared, and for days haunted the shed and porches, even trying persistently to enter the windows of the home, apparently in search of his lost mate. The little wrens, which for years have nested in the many houses provided for them about the premises, will always come into the house if an opening is found. An aperture in the wall for the admission of the hose that feeds a large aquarium, always is under observation and if found open insures a visit from the wren who will sometimes perch on the side of my work basket when I am at work and has even been known to perch on an extended finger. These domiciliary visits are not encouraged, however, for fear he may fall a victim to one of the many Persian kittens that claim special residence here.

The wren is, of all our birds, the most easily provided for, as it is not at all fastidious as to the quarters provided, and will nest in single or apartment houses with equal content. A favorite box with one pair was a codfish box with the lid shoved on and an inch-wide hole cut through near the lower corner. Almost any box that is available can be fashioned into homes for birds by the use of hammer and saw. Take a starch or soap box, for instance. Remove the lid, saving the pieces in as perfect condition as possible. Put two partitions through the box, the first being a straight piece the length of the box and as wide as the inside depth. Then another piece the 


\section{MAKING OF A FLOWER GARDEN}

length of the inside width of the box must be cut and a slit sawed half way through the middle and a corresponding slit through the lengthwise piece. This allows the two pieces to fit together, dividing the box into four compartments. The lid should then be nailed in place and an inch hole bored with an auger near the lower right hand corner of each compartment. Two of these may be on the front and one on each side of the box, so that one entrance need not be directly over another. Under each opening bore another small one and fit in this a peg for a lighting perch. Each compartment should be large enough for the bird to enter and turn around, as the hen always sits facing the opening when brooding her eggs and fledglings; this makes for convenience when being fed by her mate.

A roof that will shed water is more desirable than a flat surface and this may easily be fashioned by cutting two three-cornered or triangular pieces for front and back and nailing them in place and attaching straight sides to these to form the slanting roof. Very presentable houses may be constructed in this simple way if a little attention is given to detail in painting. Green makes a good foundation color for box and roof, and the triangular pieces may be striped in green and white with white for the perches. Larger boxes for martins may be made in the same way, mak- 


\section{BIRD HOUSES AND NATATORIUMS 231}

ing the inside diameter of nests six by six by six with the entrance about two inches in diameter.

Very attractive houses may be made from cheese boxes, but are more trouble to construct, owing to the difficulty of adjusting the partitions, but they well repay the extra labor. For a five room bluebird or martin house a single cheese box is used and the first thing to do is to find a round piece of wood-a barrel head is just right-for the top and bottom. Find the exact center of these and of the cheese box and with an inch and a quarter auger cut a hole through all four pieces, having them exactly in line. These are for the insertion of a piece of wood-a piece of a curtain pole is just right-around which the box is to be built. Pieces of wood as long as the distance from the center hole to the edge of the box and as wide as its depth are next fitted into the box and nailed with thin brads to sides and bottom. Holes are then eut with a very sharp bit near the bottom of each compartment-two inches for martins, one and three-fourths inches for fly catchers, one and onefourth inches for chickadees, one inch for wrens and one and a half inches for Carolina wrens and tree swallows. Under each opening place a perch as suggested for the square boxes, and attach the top and bottom to the box. To do this it will be necessary to introduce some solid strips of wood, round or square, inside the nests, as the thin wood of which 


\section{MAKING OF A FLOWER GARDEN}

the cheese boxes are made affords little chance for solid work.

The top and bottom being in place, the ornamental part of the house will be next in order. A very pretty finish is made by securing a strip of round wood an inch or a trifle more in diameter-a window shade roller will do-and saw it into length exactly that of the space between the top and bottom boards and nail these in place, forming a pillared portico or veranda about the house. The window pole is now inserted into the holes provided for it and three small iron or wooden brackets attached to the part that extends above the house, nailing them to the top and to the pole, which should have some ornamental heading to finish it. Three larger brackets finish the under part of the box. The whole should then be given a coat of dark green paint-the green used for outside window blinds wears best-and the trimming, pillars, perches, brackets and pole should be painted white. The free end of the pole should then be fitted into an iron water pipe about eight or ten feet long and this set in a socket in the ground. An old well cylinder set in concrete makes an excellent socket and by this installation the pole can be easily lifted out to clean the house each spring. Ten-room houses are constructed in the same way by using the double cheese boxes, putting in partitions half the depth of the box, fitting a round piece of wood over these and 


\section{BIRD HOUSES AND NATATORIUMS 233}

supplying another series of partitions, care being taken that the openings alternate, no one being over another. This style of house will prove very acceptable to martins and birds which dwell in colonies.

Often one has in his possession old-fashioned wooden clocks which have long since ceased to be of service and have been relegated to the garret. These make excellent wren houses, as it is only necessary to remove the works, insert partitions and supply entrances, and give a coat of weather-proof paint and erect them in some convenient pasition under the roof of the porch or on the trunk of a tree. Once one has formed the bird house habit it is surprising how many things one finds adaptable. Small kegs, with a thatched roof, may be suspended from the limbs of a tree and one of the prettiest houses I have seen was made from a candy pail with a barrel head for a bottom and a peaked thatched roof, all erected on a pole and giving house room to a number of families of wrens. In putting up houses on trees it is usually most convenient to drill a hole in the back, near the top, and driving a spike in a tree hang the house on that. This does very well if the proximity of limbs afford a little support so that there is no danger of its being blown down. A more secure way is to nail a strip of board to the back of the box, letting it extend two or three inches beyond the box, and nail 


\section{MAKING OF A FLOWER GARDEN}

through this into the tree. Thus adjusted it will be secure against almost any wind.

Cheese boxes have not served their full duty when used exclusively for nests, for they make excellent feeding stations for the winter birds. For this purpose I like two lids, separated by three pieces of curtain pole about ten inches long, the upper, of course, turned downward and the lower up. They should be nailed to the top of a post at a convenient place for filling and will be found well patronized by the birds. Grain, bread crumbs, weed seeds, any food suitable for small birds,-may be used to attract them. For the larger birds, like jays, rose breasted grossbeaks and cardinals, the spiked feeding stations are desirable. These may be simply a block of wood with a spike driven through it nailed to a convenient post or tree and an ear of corn impaled on the spike. A chunk of bread or of suet will attract any of the woodpecker family. Such a station in view of my dining room window has for several summers been full of interest from the regular visits of a pair of red-headed woodpeckers which feed and carry portions of food to their nest in a tree across the street and as soon as the young are large enough to fly bring them to feed also. A piece of wood a foot or fifteen inches long and about nine inches wide is pointed at each end and two pieces of board about eight inches long and five wide are nailed to the 


\section{BIRD HOUSES AND NATATORIUMS 235}

two top sides to form a roof. About two-thirds of the distance from the top a square of wood with a spike nailed through from the back is nailed and a perch, consisting of a bit of tree branch, is nailed beneath for the accommodation of the woodpeckers. The jays usually stand on the corn or spike to eat, but woodpeckers eat from below up. Most feeding stations and houses attached to trees are more satisfactory if painted an inconspicuous green or gray. The sliding cars which run on wires and so afford no footing for cats or squirrels are other satisfactory structures, easily made by any one handy with tools. These are usually about a foot long by six inches wide and have pointed ends about nine inches high which support two roof boards. A narrow ledge is put along the open sides to prevent the food spilling out and a wire is run, through a hole in the end gables, from tree to tree or from other supports-the end of a porch and a tree being convenient. A cord attached to the car and running over a pulley on the tree will allow the car to be drawn up to the porch to be filled and then slid back along the wire until far enough from the house to give confidence to the birds when first they begin to use it.

In the summer the water supply is more important than food, as the birds will be able to forage for themselves and seldom affect localities lacking in natural food, but much may be done to furnish a supply 


\section{MAKING OF A FLOWER GARDEN}

of such food as is especially acceptable to birds by planting trees, shrubs and grains that will attract them. No one tree can be planted that will attract so wide a variety of birds as the Russian mulberry. From the time the first fruit begins to redden in June until sometime in September the trees will be alive with a surprising variety of birds and many of the early spring migrant birds will visit the trees for insects they find on the twigs and the seeds of the berries which they gather from the ground. Last spring a large flock of juncos stayed about the trees several weeks, scratching over every foot of the ground in search of food and so tame were they that they paid little attention to my presence, scratehing away, with both feet at once, within a yard of me. Mountain ash attracts many migrant birds and the trees are seldom without birds as long as a berry remains. Where mulberries are planted little if any damage is done to other fruit, as the birds much prefer them and many fruit growers plant them for protection. The following list of shrubs, trees and vines which attract birds will be suggestive, as some, or all of them, may be found growing wild in one's vicinity and may be easily transplanted to one's door yard. 


\section{BIRD ·HOUSES AND NATATORIUMS 237}

\begin{tabular}{|c|c|c|}
\hline $\begin{array}{l}\quad \text { TREES. } \\
\text { Russian mulberry } \\
\text { Dogwood } \\
\text { Wild sand cherry } \\
\text { Black cherry } \\
\text { Choke cherry } \\
\text { Hack berry } \\
\text { Box elder } \\
\text { White thorn } \\
\text { White ash } \\
\text { Mountain ash } \\
\text { European ash } \\
\text { Balsam fir } \\
\text { Red cedar } \\
\text { White spruce } \\
\text { Hemlock } \\
\text { Pitch, white and } \\
\text { Norway pine }\end{array}$ & $\begin{array}{l}\text { BHROBS. } \\
\text { Elders } \\
\text { Raspberries } \\
\text { Blackberries } \\
\text { Sumacs } \\
\text { Juniper berries } \\
\text { Service berries } \\
\text { Holly berries } \\
\text { Huckleberries } \\
\text { Spice bush } \\
\text { Haws } \\
\text { Snow berries } \\
\text { Shad bush } \\
\text { Fever bush } \\
\text { Barberry } \\
\text { Cornels } \\
\text { Dangleberries } \\
\text { Black alder } \\
\text { Privet } \\
\text { Choke berry } \\
\text { Buckthorn } \\
\text { Swamp gooseberry } \\
\text { Wild rose } \\
\text { Thimbleberry } \\
\text { Indian currant } \\
\text { Arrow wood } \\
\text { Sheep berry } \\
\text { High bush cran- } \\
\text { berry }\end{array}$ & $\begin{array}{l}\quad \text { VINEs. } \\
\text { Wild grape } \\
\text { Virginia creeper } \\
\text { Bitter sweet } \\
\text { Moonseed } \\
\text { Matrimony vine } \\
\text { Clematis } \\
\text { Honeysuckle vine } \\
\text { Trumpet vine } \\
\quad \text { PuanT } \\
\quad \text { Sarsaparilla } \\
\text { Buckwheat } \\
\text { Bunflower } \\
\text { Japanese millet } \\
\text { Poke berry } \\
\text { Wild rice } \\
\text { Hemp } \\
\text { Oats } \\
\text { Clover }\end{array}$ \\
\hline
\end{tabular}

Sunflowers are especially interesting things to grow, for, as soon as the seeds begin to ripen, the patch will be full of linnets whose pretty little call of "See-reet, see-veet" can be heard all day long and if one goes quietly down among the tall rows of sunflowers they can be approached within two or three feet, and if alarmed will only retreat to a near-by flower. Often I have called and been answered, as their note is one of the easiest to imitate. At this season of the year 


\section{MAKING OF A FLOWER GARDEN}

the linnet is rather shabby in his old summer suit and is more intent in filling his little crop with the fattening seeds than in his personal appearance, but he is a very attractive and engaging little acquaintance at any time. A clover field is a joy indeed when it brings, in early May, the gay little bobolink, and if there is a brush heap or low tree close by where he may light and pour out his soul in song one may well begrudge any duty that calls one away from his immediate vicinity.

But to return to the question of water. Water for drinking must be available, of course, but water for bathing is just as necessary and bird baths should be scattered about the lawns and gardens, wherever they will be convenient and safe for use. They should always be placed near a tree or other resting place easily reached, for the bird cannot fly far when wet and in such condition is an easy prey for cats. A bath placed on a pedestal with a wire stretched above it a few feet from the ground is excellent. A tall stump with hollow top fitted with a large hanging basket of earthen ware, the drainage holes plugged and a perch fixed half way down the basin for the accommodation of small birds that could not bathe in the deep water, had a wire stretched from a corner of a porch to a fence some distance away and was so popular with the birds that there was never an hour of the day that did not see the wire covered with 


\section{BIRD HOUSES AND NATATORIUMS 239}

birds of all sorts waiting for a chance to bathe. Large trees nearby added security and shade. A wire nest, such as is used in poultry houses, is sunk in the ground under a windmill tower covered with wire netting and roses. The wire nest, given a coat of cement and always filled with fresh water from the tap, is much loved by brown thrushes, robins and other large birds who bathe and fly into the netting to dry and preen themselves. I have seen a dozen brown thrushes there at one time. The flickers like a dish set on the ground under the apple trees. The big lily pool, of course, attracts many birds, especially the mourning doves, and one memorable day saw three blue herons about to make a descent upon its placid waters. Fortunately for the welfare of the gold fish which, with the frogs, claim the lily pool as their especial domain, my presence frightened them away, but the presence of herons so far from the lake was something unknown before and proved quite an exciting episode.

But one need not depend entirely on houses of wood and fountains of concrete and stone for the comfort of the birds, for one may grow very commodious nests and baths of gourds with little trouble and expense, letting nature do the fashioning in many quaint and curious forms. Almost every need of the birds may be supplied at the expense of a few packets of seeds"and a little time and labor. 


\section{MAKING OF A FLOWER GARDEN}

The gourds best adapted for nests are the Turk's cap gourds, the calabash, the Hercules' club, and the dipper. The club gourds are long and about five inches in diameter and when thoroughly ripe and dry should have a hole two inches in diameter cut near the upper part of the large portion and the contents removed. The gourd should then be attached to the side of a tree in the same position a hollow limb would naturally occupy. Put à little fine sawdust in the bottom for nesting, as that is all the material used by the woodpeckers and flickers which use this form of nest. The smaller calabashes and the Turk's cap should have a hole an inch or an inch and a quarter in one side and be fastened up on the top of a porch pillar or other sheltered position for wrens or chickadees. A larger hole is necessary for bluebirds.

The large calabashes, often fifteen to eighteen inches in diameter, when sawed in two make excellent natatoriums and feeding dishes, but are not so well adapted for nests, as they cannot be divided into compartments very well.

The raising of gourds is a very simple operation, providing one has a long season in which to mature the fruit. The seed should be started very early in the house or hotbed, planting two or three seeds in thumb pots plunged in the earth of the hotbed or in a box of damp sand in a warm place in the house for 


\section{BIRD HOUSES AND NATATORIUMS 241}

best results. Plant out in a warm, sunny position when the nights and soil are warm-not before. They must have sufficient support from the start so that there will be no setback to their growth and when a sufficient number of fertile flowers have set, the ends of the vines may be shortened in order to throw the strength of the vine into the ripening of the fruit. Some seasons it is impossible to get a single ripe gourd even on strong, rampant vines, while more favorable seasons will give an abundance of fruit, but in the warmer sections of the country they should be as easily raised as squashes. They should have sufficient water at all times and good rich mellow soil. They are very fascinating things to raise, because there are so many kinds and such curious forms, and as when dried they are practicably indestructible, one good crop should furnish bird supplies for several yearș. 


\section{TABLE OF GERMINATION OF SEEDS}

In the following table it will be noticed that certain flowers appear in two or more sections. When this occurs the first section indicates the shortest time in which perfectly fresh vigorous seed, planted in a warm hotbed or in flats in the house or greenhouse should appear. The longer time is required by less vigorous seed sown under less favorable conditions and in the open ground. Self-sown seed in the open ground will usually not appear until much later than the same seed sown in a prepared seed-bed, and weeks later than seed sown in hotbed or other protected position.

\section{FROM 3-5 DAYS}

Ageratum
Ammobium
Asters
Celosia
Centaurea
Chrysanthemum
Cypress Vine
Cosmos
Calliopsis
Gilla
Hollyhock
Lavatera

Layia elegans
Leptosyne maritima
Marigold
Mimulus
Mina lobata
Salvia
Sedum
Silene schafta
Sphærogyne
Stevia
Stock

Sweet William

Tradescantia

Trifolium

Tunica:

Verbascum

Veronica

Virginian stock

Viscaria

Vittadenia

Whitlavia

Zinnia

\section{FROM 5-7 DAYS}

Acacia
Acroclinium
Asters
Amaranthus
Arabis alpina
Bellis
Beta
Brompton stock
Bromus
Browallia
Calliopsis
Candytuft
Cannabis
Carnations
Centaurea
Cacalia
Catchfy

Convorulus

Chrysanthemum Indicum

Cineraria

Clitoria

Coleus

Coreopsis

Crucianella

Cuphea

Cynoglossom

Dahlia

Dianthus

Daisy

Dolichos

Eschscholtzia

Eupatorium

Gilia

Gaillardia
Geranium
Gypsophila
Hedysarum
Hablitzia
Helenium
Helichrysum
Hibiscus
Iberis
Linum
Linaria
Lobelia
Lupinus
Lychnis
Ice plant
Malva
Matthiola


FROM 5-7 DAYS (Continued)

Mesembryanthernum Nigella

Mignonette

Morning Glory

Mirabilis

Momordica

Abutilon

Achimines

Agrostemma

Antirrhinums

Armeria

Abronia

Adonis

Balsams

Begonias

Bartonia

Baloon vine

Bryonopsis

Clarkia

Calceolaria

Canna

Capsicum

Campanula

Nicotiana

Enothera

Picotee

Pinks
Scarlet runner

Salpiglossis

Schizanthus

Sunflower

Wall flowers

FROM 7-8-10 DAYS

Commelyna

Deutzia

Digitalis

Dracocephalum

Erianthus

Gaura

Gilia

Gloxinia

Gnaphalium

Hibiscus

Humulus

Kaulfussia

Lychnis

Lathyrus

Molina

Pansy
Viola

Papaver

Pentstemon

Petunia

Phacelia

Phlox Drummondi

Poinsettia

Potentilla

Portulaca

Sweet sultan

Rudbeckia

Thunbergia

Tropæolum

Valerian

Verbena

Zea

FROM 10-12 DAYS

Achillea

Alyssum saxatile

Artillery plant

Arctotis grandis

Anchusa

Aquilegia

Asphodelus

Aubretia

Bidens

Blue bells

Brachycome

Calandrina

Calonycton

Campanula

Clianthus

Cyperus

Dicentra

Euphorbia

Feverfew

Galtonia

Geum

Gypsophila

Helianthemum

Linaria

Ipomopsis

Larkspur

Scabiosa

Scutellaria

Silphium

Spiræa

Sweet peas

Xeranthemum

\section{FROM 12-15 DAYS}

Anemone sylvestris Achyranthus Acacia
Antigonon

Asters, perennial

Callirhoe
Campanula Tenorei

Calandrina

Datura 


\section{MAKING OF A FLOWER GARDEN}

FROM 12-15 DAYS (Continued)

Didiscus

Delphiniums

Gazanopsis

Gourds

Hunnemania

Lantana

Kudzu vine

Mandevillea

Maurandia
Myosotis

Nicotiana

Nierembergia

Peas

Perilla

Petunia, double

Platycodon

Polemonium
Ricinus

Ranunculus

Shasta daisy

Stokesia

Thalictrum

Torenia

Verbena venosa

Vinca

\section{FROM 15-20 DAYS}

\section{Acanthus \\ Agapanthus \\ Anemone \\ Antigonon \\ Armeria \\ Asparagus \\ Boeconia \\ Calla}

Cobæa scandens
Cuphæa
Dictamnus
Geranium
sanguineum
Heliotrope
Impatiens sultana
Hemerocallis

Iris

Liatris spicata

Primula sinensis

Rivina humilis

Smilax, Boston

Solanum robustum

Passiflora

Wisteria

\section{FROM 20-35 DAYS}

\section{Adlumia}

Clianthus

Baptisia australis

Berberis vulgaris

Campanula fragilis

Campanula

Leutweiana
Clematis integrifolia Musa ensete

Cianthus Dampieri Phlox, perennial

Delphinium nudicaule

Funkia

Gentiani acaulis

Hibiscus speciosa

Clematis diversifolia Humea elegans
Phormium

Physanthus

Tritoma uvaria

Yucca

Wild cucumber Cyclamen

\section{ONE YEAR OR MORE}

$\begin{array}{lll}\text { Adlumia } & \text { Fuchsias } & \text { Lupinus polyphyllus } \\ \text { Ampelopsis } & \text { Geranium } & \text { Musa } \\ \text { Anthericum } & \text { sanguineum } & \text { Tradescantia } \\ \text { Clematis, in variety } & \text { Iris } & \text { Viola odorata } \\ \text { Dictamnus } & \text { Lilies } & \end{array}$






